AUTARQUIA ASSOCIADA À UNIVERSIDADE DE SÃO PAULO

COMPÓSITOS DE POLIETILENO DE ALTA DENSIDADE E BORRACHA DE EPDM REPROCESSADOS E APLICAÇÃO DA RADIAÇÃO IONIZANTE NA MODIFICAÇÃO DE SUAS PROPRIEDADES

Jessica Raquel Cardoso

Dissertação apresentada como parte dos requisitos para obtenção do Grau de Mestre em Ciências na Área de Tecnologia Nuclear - Aplicações

Orientadora:

Profa. Dra. Áurea Beatriz Cerqueira Geraldo 
INSTITUTO DE PESQUISAS ENERGÉTICAS E NUCLEARES

Autarquia associada à Universidade de São Paulo

COMPÓSITOS DE POLIETILENO DE ALTA DENSIDADE E BORRACHA DE EPDM REPROCESSADOS E APLICAÇÃO DA RADIAÇÃO IONIZANTE NA MODIFICAÇÃO DE SUAS PROPRIEDADES

Jessica Raquel Cardoso

Dissertação apresentada como parte dos
requisitos para obtenção do Grau de
Mestre em Ciências na Área
de Tecnologia Nuclear - Aplicações
Orientadora:
Profa. Dra. Áurea Beatriz Cerqueira Geraldo

Versão Corrigida

Versão Original disponível no IPEN

São Paulo

2016 


\section{AGRADECIMENTOS}

Agradeço à Dra. Áurea pela orientação, incentivo e atenção durante este trabalho.

À Comissão Nacional de Energia Nuclear (CNEN) pela bolsa concedida.

À minha mãe Elzia e ao meu padrasto Carlos pelo amor, incentivo e apoio.

Ao pessoal do grupo de estudos, Maiara, Eduardo, Thais, Paula e Leandro pelo apoio e companhia neste período.

Ao meu namorado Joachim pelo amor, apoio e companhia neste período.

Aos meus irmãos Veridiana, Luciana e Lucas pela amizade, compreensão e incentivo.

Aos professores Mauro e Cravala do Laboratório de Engenharia de Materiais da Universidade Presbiteriana Mackenzie por cederem o equipamento para os testes de impacto.

Agradeço também ao pessoal do CTR, Djalma, Elizabeth, Carlos Gaia, Dr. Leonardo e Julio Harada pelas contribuições que fizeram ao meu trabalho. 
"Se a aparência e a essência das coisas coincidissem, a ciência seria desnecessária”.

(Karl Marx) 


\title{
COMPÓSITOS DE POLIETILENO DE ALTA DENSIDADE E BORRACHA DE EPDM REPROCESSADOS E APLICAÇÃO DA RADIAÇÃO IONIZANTE NA MODIFICAÇÃO DE SUAS PROPRIEDADES
}

\author{
Jessica Raquel Cardoso
}

\begin{abstract}
RESUMO
A geração de passivos ambientais após o término da vida útil dos materiais poliméricos é uma realidade que está sendo mudada devido a reciclagem desses materiais. A obtenção de novos materiais a partir do seu reuso traz vantagens com a diminuição de custos no produto final, já que reduz a produção da matéria prima virgem, além de minimizar a quantidade de rejeitos. Neste trabalho, a borracha EPDM vulcanizada foi reprocessada termicamente por irradiação e envelhecimento para que ocorresse a sua desvulcanização, visando obter melhor desempenho no processo de reciclagem; o polietileno de alta densidade (PEAD) foi reprocessado vinte vezes de modo a obter um termoplástico reciclado. Com esses componentes foram obtidos compósitos extrudados contendo $1 \%$ e $5 \%$ da borracha (com e sem tratamento térmico) dispersa na matriz reprocessada de PEAD. A compatibilização entre os componentes foi obtida testando alguns tipos de substâncias e nesse sentido, o metacrilato de glicidila (GMA) foi o que promoveu o melhor resultado. Os compósitos também foram submetidos ao processo de irradiação por feixe de elétrons nas doses de 50 kGy e 100 kGy e a comparação entre os materiais irradiados e não irradiados foi realizada a partir de análises por FTIR, TG, DSC, MEV e testes mecânicos (tração, impacto e dureza). Os compósitos apresentaram-se homogêneos e a interface entre a borracha e a matriz polimérica apresentou-se contínua. Observou-se que tanto 0 reprocessamento termocisalhante quanto a irradiação promovem alterações em nível molecular de modo que a reticulação e a degradação ocorrem simultaneamente. A adição de EPDM nas concentrações estudadas foi fundamental na promoção da reticulação do material. Com processo de irradiação, os compósitos apresentaram melhoria nas propriedades mecânicas.
\end{abstract}




\title{
REPROCESSED HIGH DENSITY POLYETHYLENE AND EPDM RUBBER COMPOSITES AND APPLICATION OF IONIZING RADIATION ON ITS PROPERTIES MODIFICATION
}

\author{
Jessica Raquel Cardoso
}

\begin{abstract}
The generation of waste after service end-life of polymeric materials is a reality that is being changed because of the recycling of these materials. Obtaining new materials from its reuse brings benefits to the reduction of costs in the final product, since it reduces the production of virgin raw material, while minimizing the amount of waste. In this work, the vulcanized EPDM rubber was thermally reprocessed by both simultaneous irradiation and oven aging to perform its devulcanization to improve performance in the recycling process; high density polyethylene (HDPE) was reprocessed twenty times so as to obtain a recycled thermoplastic. These both components were extruded to obtain composites containing $1 \%$ and $5 \%$ of rubber (with or without heat treatment) dispersed in reprocessed HDPE matrix. The compatibility between the components was obtained testing some kinds of substances and accordingly, the glycidyl methacrylate (GMA) promoted the best result. The composites were also subjected to irradiation process by electron beam at doses of $50 \mathrm{kGy}$ to $100 \mathrm{kGy}$ and analysis by FTIR, TG, DSC, SEM and mechanical tests (traction, impact and hardness) were carried out to compare irradiated and non-irradiated materials. The composites had become homogenous and the rubber and the polymeric matrix interface presented to be continuous. It was observed that both processes thermal-shearing and irradiation promote changes at the molecular level so that crosslinking and degradation occur simultaneously. The addition of EPDM in the studied concentrations was important to promote the material crosslinking. The composites showed improvement in mechanical properties with the irradiation process.
\end{abstract}




\section{SUMÁRIO}

\section{Página}

1. INTRODUÇÃO …………………………………………………………………………… 9

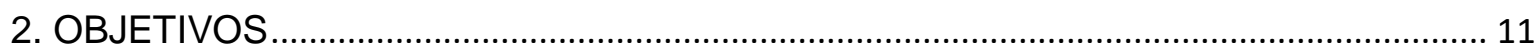

2.1 Objetivos Específicos.................................................................................................... 11

3. FUNDAMENTOS TEÓRICOS ………………………………………………………….... 12

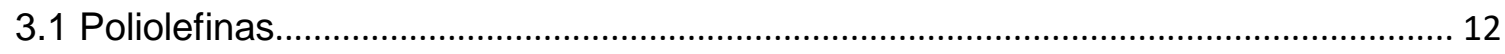

3.1.1 Polietileno de Alta Densidade (PEAD) ................................................................ 13

3.1.2 Degradação e reprocessamento do PEAD …………………………………….... 13

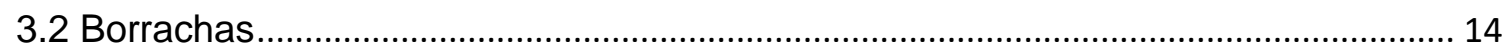

3.2.1 Terpolímero de EPDM ………………………………………………….... 15

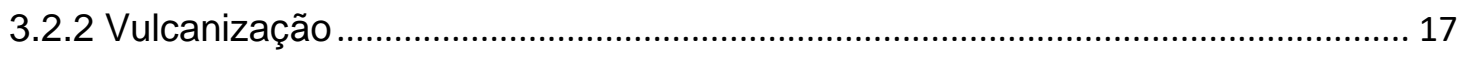

3.2.3 Desvulcanização de Borrachas................................................................................. 18

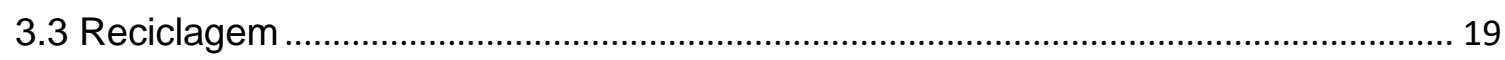

3.3.1 Reciclagem da Borracha ………………………………………………………. 21

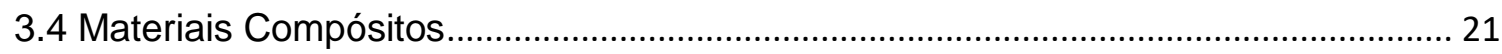

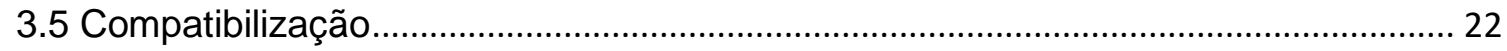

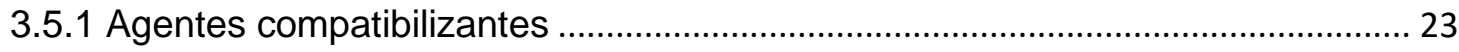

3.5.2 Metacrilato de glicidila (GMA) ..................................................................... 24

3.6 Trabalhos Anteriores com PEAD e Borracha EPDM ………………………………. 24

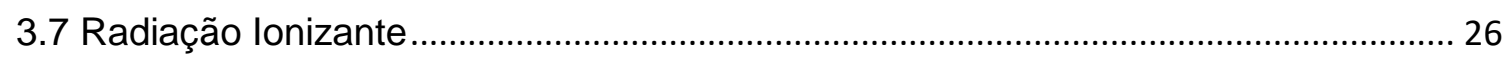

3.7.1 Efeitos da radiação ionizante em polímeros ……………………………………... 26

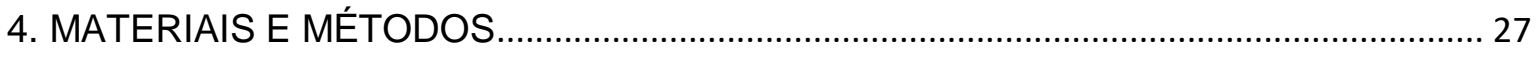

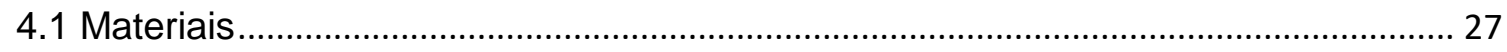

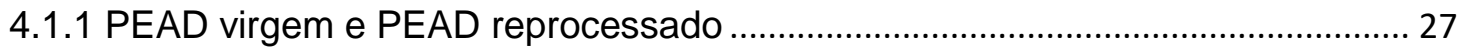

4.1.2 Borracha EPDM sem tratamento térmico (ST) e com tratamento térmico (TT) 27 
4.2 Métodos

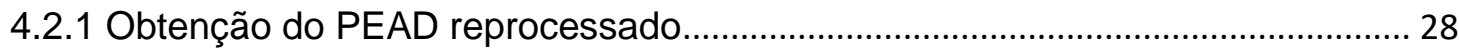

4.2.2 Borracha EPDM com tratamento térmico .......................................................... 29

4.2.2.1 Envelhecimento térmico em estufa ..................................................................... 29

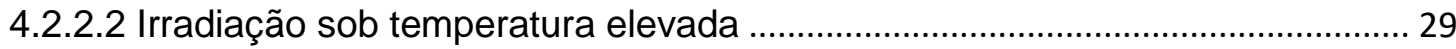

4.2.3 Obtenção dos compósitos PEAD/EPDM reprocessados...................................... 30

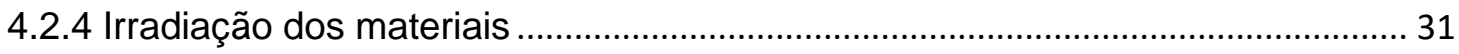

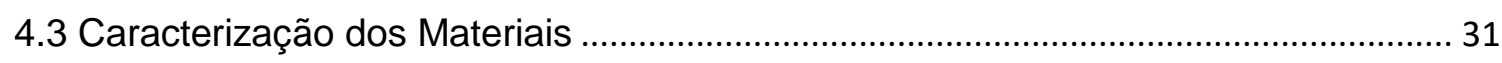

4.3.1 Espectrometria no Infravermelho por Transformada de Fourier (FTIR) ............. 32

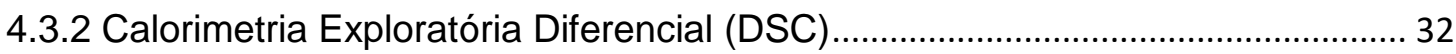

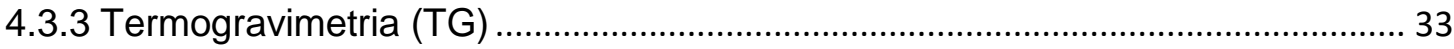

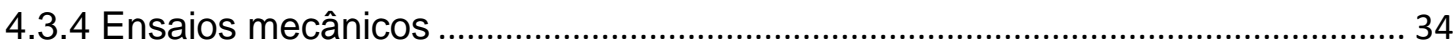

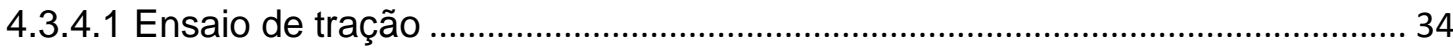

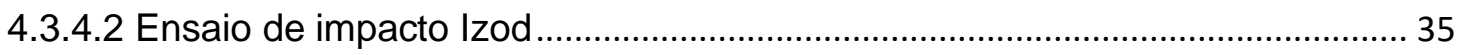

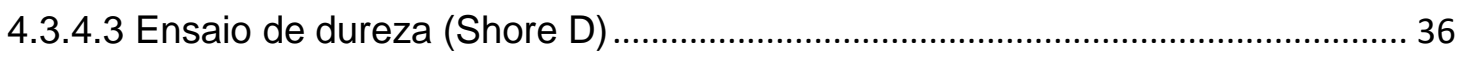

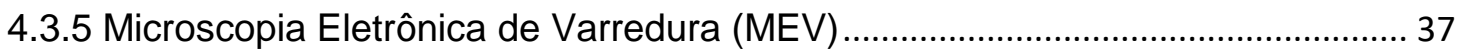

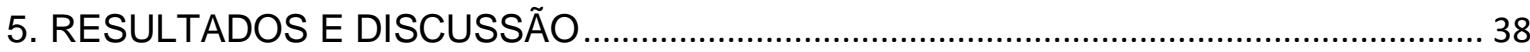

5.1. Tratamento térmico da borracha EPDM vulcanizada ............................................... 38

5.1.1 Irradiação com aquecimento simultâneo ……………………………………....... 38

5.1.2 Envelhecimento térmico da borracha EPDM ..................................................... 41

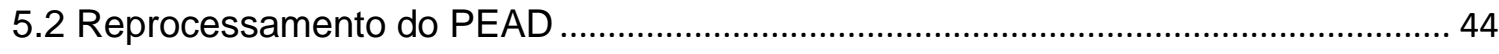

5.2.1 Espectrometria no Infravermelho por Transformada de Fourier (FTIR) ............. 44

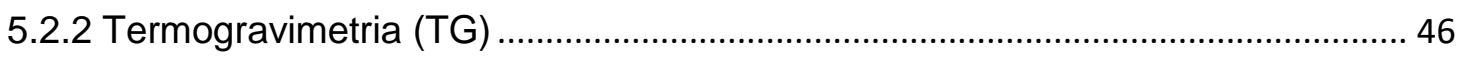

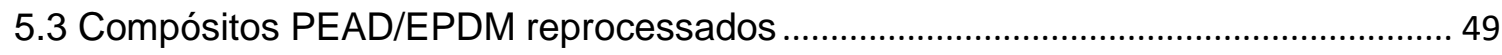

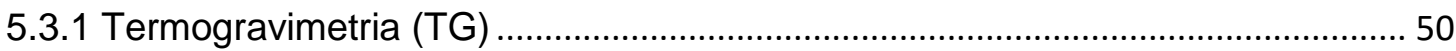

5.3.2 Calorimetria Exploratória Diferencial (DSC) ........................................................ 55

5.3.3 Espectrometria no Infravermelho por Transformada de Fourier (FTIR) ............. 62 
5.3.4 Ensaios Mecânicos 66

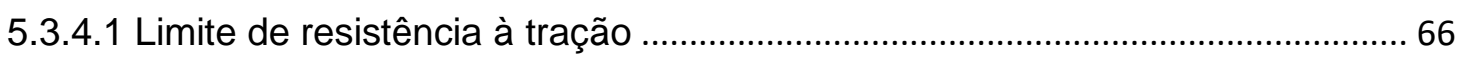

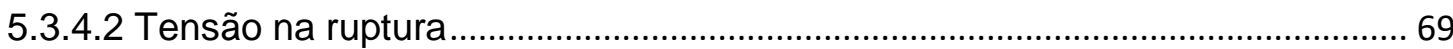

5.3.4.3 Resistência ao Impacto Izod ................................................................................ 72

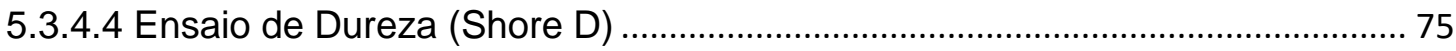

5.3.5 Microscopia Eletrônica de Varredura (MEV) …..................................................... 78

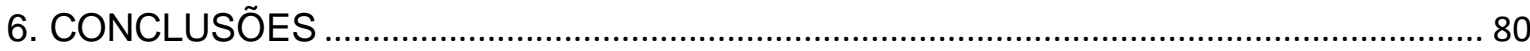

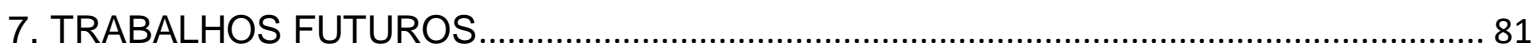

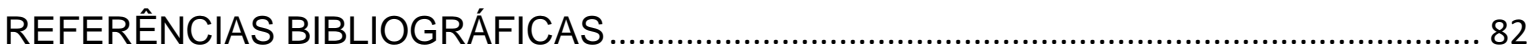




\section{INTRODUÇÃO}

O polietileno de alta densidade (PEAD) é classificado como uma commoditie por ter vasta aplicabilidade industrial em função da sua alta conformabilidade, resistências térmica e química, com relativo baixo custo. Analogamente, a borracha EPDM (borracha do monômero etileno-propilenodieno) é um dos elastômeros sintéticos também mais usados por apresentar alta resistência ao calor, à oxidação, ao ozônio e ao envelhecimento por exposição climática. O EPDM é empregado em grande escala na indústria automotiva, no setor de construção civil e na indústria de manufatura de peças mecânicas em geral (KARPELES, 2001).

Há uma tendência da indústria na substituição da borracha pura por componentes termoplásticos adicionados a elastômeros em diversas aplicações, como utensílios, peças ou itens automobilísticos, produtos hospitalares e produtos de engenharia. Esses materiais são conhecidos como termoplásticos elastoméricos vulcanizados (TPV), quando se realiza a vulcanização final do material após a mistura, e termoplásticos elastoméricos (TPE), quando se faz o uso de um elastômero desvulcanizado (MANGARAJ, 2005).

Nas misturas de diferentes materiais poliméricos, é muito comum o uso de materiais que facilitem a compatibilidade desses materiais. Agentes compatibilizantes ou agentes de acoplamento são usados em blendas ou misturas poliméricas para melhorar a adesão entre as fases constituintes, promovendo melhor dispersão de partícula e muitas vezes a diminuição do tamanho dessas partículas (KONING, 1998).

A alta produção de materiais plásticos e a consequente alta geração de passivos impulsiona a reciclagem, o reuso e o reprocessamento desses materiais. Em um sistema de reciclagem, a produção de novos insumos a partir da reutilização de materiais preexistentes é vantajosa em termos de redução da produção de matéria prima virgem, que tem como consequência a diminuição do custo final do produto (MANO, 2005). No entanto, com a reciclagem e reprocessamento do material plástico há a perda de propriedades em relação ao polímero original, já que inclui novas etapas de fragmentação, cisalhamento e fusão. 
O processamento por radiação torna-se então uma alternativa na possibilidade de incremento da resistência mecânica já que garante maior durabilidade dos materiais antes refugados (CZVIKOVSZKY, 2003). Além disso, a radiação ionizante tem utilização importante na modificação de materiais poliméricos. Com este processo, dois efeitos concorrentes e simultâneos são observados: a sua degradação e também a formação de ligações cruzadas entre as moléculas. A preponderância de um efeito sobre o outro, depende de condições empíricas (CHARLESBY, 1953).

Este trabalho, que conjuga o reprocessamento de dois tipos de componentes, o PEAD e o EPDM (vulcanizado e desvulcanizado) para formação de compósitos, onde se utiliza a radiação ionizante na condição energética necessária para promover alterações moleculares que conduzirão a efeitos macroscópicos importantes, está dividido em: capítulo 1, com a introdução deste estudo; capítulo 2, com os seus objetivos; capítulo 3, com os fundamentos teóricos deste tema; capítulo 4 , com os materiais e métodos utilizados para a obtenção e caracterização dos compósitos; capítulo 5, onde são apresentados os resultados e sua discussão; capítulo 6 , onde são apresentadas as conclusões, e finalmente no capítulo 7 , são apresentadas as sugestões de trabalhos futuros que foram abertas a partir deste estudo. 


\section{OBJETIVOS}

O principal objetivo deste trabalho foi obter um compósito polimérico de polietileno de alta densidade (PEAD) com borracha do monômero etilenopropileno-dieno (EPDM), ambos componentes reprocessados, de modo a obter um produto final com maior resistência mecânica.

\subsection{Objetivos Específicos}

Foram objetivos específicos:

a) Realizar o reprocessamento do PEAD em vinte ciclos e caracterizar o produto final;

b) Desvulcanizar a borracha EPDM com distintos processos e caracterizar os produtos obtidos;

c) Obter misturas extrudadas de PEAD (virgem e reprocessado) com borracha EPDM (vulcanizada e desvulcanizada), com e sem o uso de substância compatibilizante;

d) Aplicar o processo de irradiação ionizante nos compósitos PEAD/EPDM obtidos;

d) caracterizar os compósitos de PEAD e EPDM irradiados e não irradiados, por meio de espectroscopia no infravermelho, análises térmicas e mecânicas. 


\section{FUNDAMENTOS TEÓRICOS}

\subsection{Poliolefinas}

A primeira poliolefina produzida (o polietileno) foi sintetizada por dois pesquisadores da empresa inglesa ICl (Imperial Chemical Industries), sendo patenteada em 1937. A reação de polimerização por radicais livres envolvia quatro etapas básicas: iniciação, propagação, terminação, e transferência de cadeia. Todo polietileno produzido até a década de 1950 provinha desta empresa. Nesse processo realizado em alta pressão eram obtidos polietilenos com muitas ramificações e massa molecular moderada, nomeado posteriormente polietileno de baixa densidade (PEBD) (OLABISI, 2016).

Apesar de o processo original do PEBD não envolver o uso de catalisadores, suas tecnologias do reator de autoclave e reator tubular ainda estão em uso, já que essas tecnologias se adaptaram a uma variedade de catalisadores para produzir uma variedade de poliolefinas, como: o Polietileno de Baixa Densidade (PEBD ou LDPE), o Polietileno de Baixa Densidade Linear (PEBDL ou LLDPE), o Polietileno de Muito Baixa Densidade (PEMBD ou VLDPE), o Polietileno de Ultra Baixa Densidade (PEUBD ou ULDPE), o Polietileno de Média Densidade (PEMD ou MDPE), o Polietileno de Alta Densidade (PEAD ou HDPE), os copolímeros de etileno-octeno, o Polipropileno (PP), o PP de bloco estérico, as olefinas de copolímeros em bloco, os copolímeros de propilenobutano, os elastômeros baseados em propileno, os plastômeros de poliolefinas, a poli(alfa-olefina), e o etileno-propileno-dieno (EPDM) (OLABISI, 2016).

As poliolefinas são conhecidas por demandarem baixa energia nos processos de fusão e polimerização. Entre os materiais plásticos do tipo commoditie, as poliolefinas representam $50 \%$ da produção e consumo global (THE ECONOMIST, 2012).

Com uma vasta aplicação na indústria, as poliolefinas são mais comumente usadas como embalagens e materiais descartáveis. Outras aplicações são encontradas nas áreas de agricultura, construção, transportes, utensílios, eletrônicos e comunicações (OLABISI, 2016). 
A seguir, são apresentadas as características do Polietileno de Alta Densidade, que é objeto de estudo deste trabalho.

\subsubsection{Polietileno de Alta Densidade (PEAD)}

Em uma reação de polimerização, o tipo de catalisador define se a reação deve ocorrer com alta ou baixa pressão. A partir das pesquisas de Ziegler e Natta, reações de polimerização com baixa pressão tornaram-se possíveis. Seus catalisadores de trietil-alumínio e tetracloreto de titânio foram os primeiros a apresentar resultados satisfatórios para o processo de polimerização de etilenos (COUTINHO, 2003).

O processo Philips também ocorre a baixa pressão. Nele, a pressão utilizada fica em torno de $50 \mathrm{~atm}$ e a faixa de temperatura abaixo de $100{ }^{\circ} \mathrm{C}$. $\mathrm{O}$ catalisador empregado é o óxido de cromo suportado em alumina e ativado por uma base. Este processo produz um polietileno com menos ramificações, em comparação ao polietileno produzido pelo processo de Ziegler e Natta, e como é menos ramificado, possui maior grau de cristalinidade e maior densidade (COUTINHO, 2003).

As propriedades do polímero com estrutura linear, poucas ramificações e alto grau de cristalinidade (até $90 \%$ cristalino) são as características intrínsecas do Polietileno de Alta Densidade (PEAD) (COUTINHO, 2003). Essas propriedades conferem ao PEAD características como rigidez elevada, resistências à fluência, à abrasão, ao impacto, ao tensofissuramento sob tensão ambiental e química (CANEVAROLO, 2010).

O PEAD é mais usado para a produção de filmes, produtos de extrusão de sopro e peças injetadas. Estes itens representam, respectivamente, $40 \%$, $35 \%$ e $12 \%$ em volume de toda a produção; outras aplicações somam $13 \%$ em volume (BRASKEM, 2008).

\subsubsection{Degradação e reprocessamento do PEAD}

O estudo da reciclagem de materiais envolve a investigação do seu comportamento quanto à reprocessabilidade e degradação. Segundo a literatura, o PEAD pode degradar-se em qualquer circunstância, desde sua obtenção até durante seu uso final, porém é durante o seu processamento que a degradação 
pode ocorrer mais rapidamente, devido aos efeitos conjuntos de altas temperaturas com o cisalhamento do material.

A degradação do PEAD foi bastante estudada na literatura; os estudos convergem no sentido de que durante o processamento desse material, reações de reticulação e de cisão da cadeia polimérica por termo-oxidação ocorrem simultaneamente.

Epacher et al (1999) estudaram a degradação do PEAD por múltiplas extrusões. Os resultados foram obtidos por teste de MFI (Melt Flow Index) e aparecimento de cor no PEAD (índice de amarelecimento). O MFI das amostras testadas diminuiu, o que indica a presença de reticulação. Porém, ao acrescentar antioxidante, esse índice permaneceu estável até para altas concentrações. Também se verificou que na presença de antioxidantes fenólicos (Irganox 1010), há o aparecimento de cor (amarelecimento) no PEAD reprocessado.

Mesquita (2010) estudou as mudanças ocorridas na estrutura química e nas propriedades do PEAD provocadas por diferentes condições de extrusão, com perfis de temperatura variados e diferentes aditivos antioxidantes. O PEAD utilizado foi um bimodal de alta massa molecular, com catalisador Ziegler-Natta. Os resultados mostraram que os antioxidantes utilizados (tetrafenólicos e fosfitos) protegeram o PEAD da degradação, porém, estes mesmos antioxidantes contribuíram com uma maior alteração de cor nas amostras analisadas (índice de amarelecimento). As mais altas temperaturas do processo provocaram maior cisão das cadeias das amostras sem antioxidantes, o que foi menos aparente nas amostras com antioxidantes.

\subsection{Borrachas}

As borrachas ou elastômeros são materiais naturais ou sintéticos que possuem a capacidade de deformarem-se durante a aplicação de uma força e retornarem ao seu formato original após essa força ser removida.

As borrachas naturais são materiais poliméricos oriundos da árvore seringueira (Hevea brasiliensis). A seiva dessa árvore é composta de látex, que após processado por coagulação, secagem da seiva e posterior vulcanização, são adicionadas cargas preenchedoras. A borracha natural é basicamente composta 
por isopreno, que contém a unidade de repetição $-\mathrm{CH}_{2} \mathrm{C}\left(\mathrm{CH}_{3}\right): \mathrm{CHCH}_{2}-$ (CANEVAROLO, 2010).

As borrachas sintéticas são compostas por borrachas nitrílicas, butadienos, neopreno, borrachas butílicas, borrachas polissulfídicas, PVC, e borrachas de silicone (WEYER e WORKMAN, 2007; CANEVAROLO, 2010).

\subsubsection{Terpolímero de EPDM}

O terpolímero de etileno-propileno-dieno (EPDM) é uma das borrachas sintéticas mais populares, a terceira mais utilizada, ficando atrás apenas do SBR (copolímero estireno-butadieno) e BR (borracha butílica). Possui boa resistência ao oxigênio, ozônio, ao calor e à luz ultravioleta, assim como boa resistividade elétrica e resistência a solventes polares (CHOI, 2013).

Na estrutura molecular do EPDM forma-se um copolímero contendo os monômeros de etileno e propileno na cadeia principal. O grupo dieno apresentase como ramificação desta cadeia e possui a dupla ligação (insaturação) responsável pela sua reatividade com átomos de enxofre e aceleradores durante o processo de vulcanização (BURROWES, 2016).

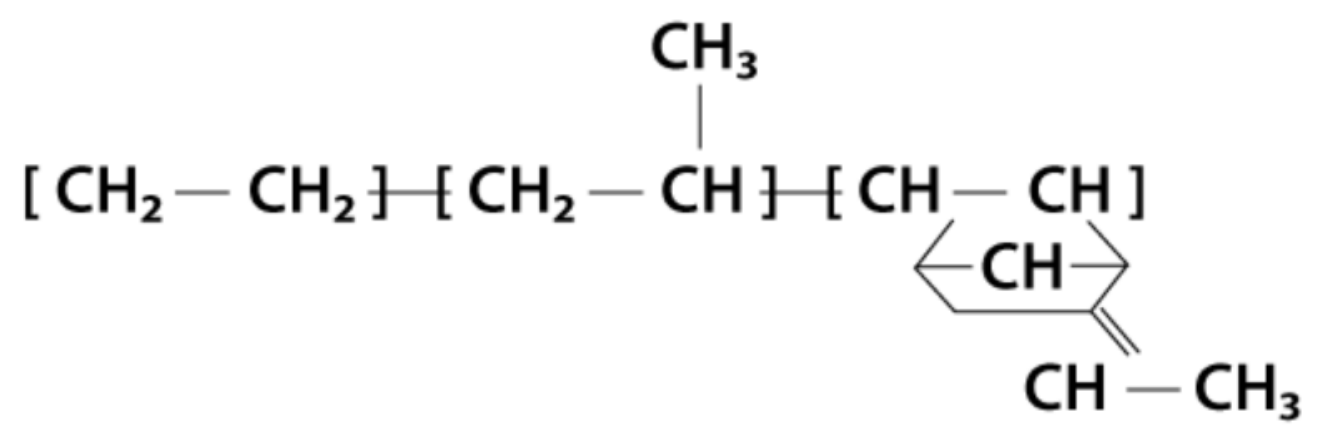

FIGURA 1: Estrutura molecular da borracha de EPDM (ASKIMYA, 2016).

O EPDM é altamente usado pela indústria automotiva e suas maiores aplicações estão em produtos como pneus, mangueiras e perfis de vedação para vidros, e entre outras aplicações, o EPDM também pode ser usado como compatibilizante em blendas ternárias (ZHANG, 2010). 
Com o EPDM é possível produzir formulações variadas para obter borrachas com distintas aplicabilidades. Nessas formulações estão presentes os seguintes compostos:

- Cargas reforçantes: como o negro de fumo que, dependendo do tamanho da partícula, pode ter grande ação reforçante (partículas finas), porém baixa capacidade de dispersão; distintos tipos de negro de fumo podem oferecer características mecânicas também distintas, bem como efeito estético. Ślicas, caulins, talco, carbonato de cálcio e alumina hidratada também são utilizadas como cargas reforçantes, sendo que cada um desses componentes específicos e suas granulometrias influenciam nas características mecânicas da borracha obtida e também de sua coloração, já que esse tipo de carga oferece um produto final de coloração branca à clara;

- Aceleradores e agentes de cura: enxofre atômico e compostos orgânicos contendo enxofre (p. ex., MBT - 2-mercaptobenzotiazol e ZMDC dimetilditiocarbamato de zinco) que são responsáveis pela vulcanização da borracha;

- Peróxidos: utilizado na vulcanização da borracha quando a presença de enxofre e tiocompostos orgânicos são indesejáveis para uma dada aplicação;

- Plastificantes: óleo mineral de base parafínica e/ou naftênica e ésteres. Os plastificantes são responsáveis pela processabilidade da borracha e são utilizados em grande escala na formulação;

- Óxido de zinco: melhoria ao envelhecimento térmico;

- Estearina: efeito de dispersibilidade de cargas;

- Antioxidantes e antiozonantes.

A TAB. 1 fornece exemplos de formulação em phr (parts per hundred of rubber - partes por 100 partes de borracha) da borracha EPDM: 
TABELA 1: Formulação da borracha EPDM.

\begin{tabular}{lll}
\hline \multicolumn{1}{c}{ Componente } & \multicolumn{2}{c}{ Concentração (phr) } \\
& \multicolumn{1}{c}{$\begin{array}{c}\text { SANTOS et al } \\
(2012)\end{array}$} & $\begin{array}{c}\text { PISTOR et al } \\
(2010)\end{array}$ \\
\hline EPDM & 100,0 & 100,0 \\
Negro de fumo & 1,0 & 157,0 \\
Óleo parafínico & 2,0 & 147,0 \\
TMTM (monosulfeto de & 1,0 & - \\
tetrametiluram) & & \\
Ácido esteárico & 0,5 & 1,8 \\
MBT & 0,5 & - \\
Óxido de zinco & 2,0 & 6,0 \\
Enxofre & 1,0 & 1,9 \\
Auxiliar de fluxo & -- & 2,0 \\
Carbonato de cálcio & - & 53 \\
Óxido de cálcio & - & 19 \\
Master aceleradores & - & 5,0 \\
\hline
\end{tabular}

Como descrito no trabalho de Pistor et al (2010), a formulação apresentada na TAB. 1 refere-se à borracha de aparas e perfis de fixação e vedação de janelas automotivas; a formulação descrita no trabalho de Santos et al (2012) refere-se ao material com aplicação na área aeroespacial.

\subsubsection{Vulcanização}

Charles Goodyear na Inglaterra e Hancock nos EUA descobriram que a borracha natural podia ser modificada se fosse adicionado enxofre à sua composição. Essa mistura resultava em melhoria nas propriedades da borracha, como resistência ao calor e ao frio, resistência mecânica e maior resistência a solventes químicos. A incorporação do enxofre à borracha ocorre em alta temperatura e pressão, por esse motivo, a esse processo foi dado o nome de "vulcanização", em homenagem ao deus romano do fogo (Vulcano) (RODGERS, 2015). 
Muitas outras substâncias já foram testadas como reagentes no processo de vulcanização, porém em termos de eficiência e custo, o enxofre ainda é o melhor material indicado para o processo. A vulcanização também tem resultados satisfatórios quando são usados peróxidos orgânicos como reagentes.

O processo de vulcanização consiste basicamente de uma série de reações químicas entre as cadeias poliméricas do elastômero, formando-se uma rede tridimensional de ligações (FIG. 2 b), denominadas ligações cruzadas (crosslinking, em inglês) que conferem mais resistência ao material.

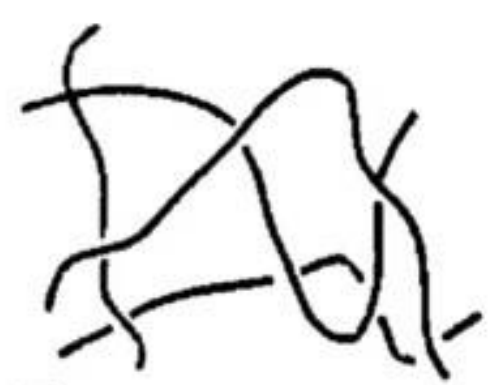

(a)

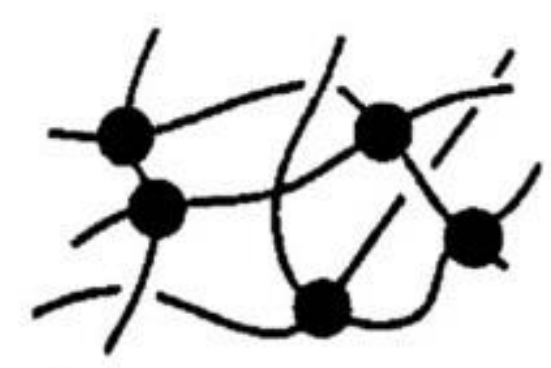

(b)

FIGURA 2: (a) estrutura molecular da borracha não vulcanizada e (b) estrutura da borracha vulcanizada (RODGERS, 2015).

\subsubsection{Desvulcanização de Borrachas}

A desvulcanização da borracha é uma tentativa de torná-la reutilizável depois de descartada. O objetivo da desvulcanização é quebrar as ligações tridimensionais que ocorreram durante o processo de vulcanização.

Várias tentativas para desvulcanizar a borracha ocorreram, utilizandose diferentes técnicas como: ultrassom, micro-ondas, degradação biológica, desvulcanização química, modificação de superfície, inchamento em soluções com solventes ativos, entre outras (RODGERS, 2015).

Hassan et al (2013) estudaram a desvulcanização por radiação gama e mecânico-química do pó de borracha inservível. O pó de borracha foi processado em um moinho de dois cilindros, na presença de várias quantidades de agentes de cura para produzir filmes (ou folhas) de borracha inservível desvulcanizada (DWR - Devulcanized Waste Rubber). Posteriormente, adicionaram os filmes de 
DWR a uma matriz de Polietileno de Alta Densidade, formando uma blenda polimérica sob irradiação gama com doses de 25 kGy, 50 kGy, 100 kGy e 150 kGy. A blenda apresentou propriedades mecânicas superiores àquelas dos polímeros antes de formarem a mistura. A dose de 150 kGy resultou em maior resistência térmica para o material.

Liu et al (2016) produziram um material compósito magnético utilizando pó de borracha inservível e pó de ferrita de bário (ímã) com auxílio de microondas para compatibilizar os materiais. Como resultado, foi comprovado que as partículas inorgânicas presentes na borracha absorveram a radiação micro-ondas, assim como a ferrita no composto. Isso causou uma semi-desvulcanização na borracha e uma modificação de superfície no pó de ferrita de bário, resultando em uma melhor compatibilidade de fases entre os materiais.

A patente US: 9.193.853 descreve um método de desvulcanização da borracha por ação microbiológica/enzimática. Este método consiste em obter um composto em pó de borracha vulcanizada, deixando-se esse pó de borracha inchar sob a ação de um solvente em solução e, posteriormente, introduzir enzimas ou micróbios na solução para que o a borracha seja consumida por esses micro-organismos e assim, desvulcanizada.

\subsection{Reciclagem}

Os materiais poliméricos, ou plásticos, são materiais altamente consumidos pela sociedade atualmente. Utensílios como sacolas, baldes, cadeiras, mangueiras, copos, mamadeiras, etc. são compostos por plásticos e são indispensáveis para nós. Porém, apesar dos benefícios do uso do plástico, como vasta moldabilidade e baixo custo, há a preocupação do que fazer após o seu descarte, tendo em vista que esses materiais podem levar séculos para se decomporem.

A preocupação em torno de resíduos plásticos no meio ambiente levou à criação de uma lei no Brasil. A Lei 12.305, de 2 de agosto de 2010, altera a lei nº 9.605 e institui a Política Nacional de Resíduos Sólidos. Essa política cobra responsabilidade das empresas pelo ciclo de vida do material produzido, incentiva o gerenciamento de resíduos pela sociedade, indústria e setor público, além de 
fomentar a prática de consumo reduzido e consciente, e aumentar a reciclagem de resíduos sólidos (BRASIL, 2010).

Os materiais plásticos, após passarem pelo consumidor final, são descartados em aterros sanitários, mas também podem ser usados como fonte de energia ou podem ser reciclados para se obter produtos novos (BNDES, 2013).

A reciclagem dos materiais plásticos ocorre após a realização de algumas etapas, como: separação, moagem, lavagem, secagem, regranulação e composição. Esse material reciclado é remoldado em novos produtos e, muitas vezes, substitui o uso da resina virgem pela indústria. Esta técnica agrega valor à cadeia produtiva do petróleo (BNDES, 2013).

Existem três tipos de reciclagem do plástico: mecânica, que compreende o reprocessamento e remoldagem da resina; energética, que é a queima do material para produção de energia para a indústria; e química, que consiste na conversão do material plástico ao seu estado de origem quando provindo da petroquímica (PIVA e WIEBECK, 2004).

Quando o material polimérico descartado apresenta características e desempenho similares às originais de quando foi produzido e provém diretamente da indústria, a reciclagem é denominada primária. Quando o material provém do consumidor final e apresenta características e desempenho diferentes dos originais, a reciclagem é considerada secundária (PIVA e WIEBECK, 2004).

Para os dados sobre reciclagem, são considerados os resíduos pós consumo. O consumo de materiais plásticos reciclados no Brasil em 2014 foi de 7,24 milhões de toneladas, com uma diminuição de $2,6 \%$ em relação à reciclagem no ano anterior (2013). O índice de reciclagem mecânica - IRmP é calculado de acordo com os resíduos gerados: (resíduo reciclado + resíduo exportado para reciclagem)/ resíduos plásticos gerados. Este índice foi 20,9\% em 2012 na média nacional, e a média desse índice para a União Europeia, por exemplo, foi de 25,4 \% (ABRELPE, 2014; HENDGES, 2014). O material mais reciclado no Brasil é o Polietileno Tereftalato (PET), que em 2012 teve 58,9\% de seus resíduos gerados reciclados, em sua maioria para uso em embalagens (ABRELPE, 2014). 


\subsubsection{Reciclagem da Borracha}

Ao contrário dos termoplásticos, as borrachas, por sofrerem o processo de vulcanização, não se dissolvem na presença de solventes químicos, nem fundem quando aquecidas, por isso não podem ser remoldadas. Todos os produtos de borracha fazem ligações cruzadas para que possuam características como força, módulo e resiliência (SADHAN, 2005).

A reciclagem da borracha é importante por motivos de meio ambiente e economia. $\mathrm{O}$ acúmulo de pneus e outros resíduos de borracha no meio ambiente tem consequências sérias como aterros caros e superlotados, incêndio de pneus e, ainda, esses materiais acabam virando criadouros de mosquitos (SADHAN, 2005).

Apesar de ser um material de difícil reprocessamento, a borracha pode ser reciclada para utilidades como pó na composição de outros materiais, como combustível para a indústria, também podendo ocorrer sua desvulcanização e reciclagem química. A própria indústria que produz a borracha tende a colaborar com a diminuição da produção de resíduos ao tentar produzir materiais cada vez mais leves, com menos borracha em seu peso e também, ao usar $25 \%$ de material reciclado em seus produtos (RODGERS, 2015). No Brasil existe uma resolução do CONAMA (Conselho Nacional do Meio Ambiente) em que obriga as indústrias de pneus a serem responsáveis por sua reutilização e reciclagem após seu descarte (BRASIL, 2009).

A mistura de pó de borracha com termoplásticos na formação de blendas ou compósitos, por exemplo, é uma alternativa viável e de interesse econômico para os resíduos desses materiais.

\subsection{Materiais Compósitos}

A combinação das propriedades dos materiais e sua variedade tem sido e ainda é estendida pelo desenvolvimento de materiais compósitos. Em geral, um compósito é considerado qualquer material multifásico que exibe uma proporção significante das propriedades de ambas as fases que o constituem, ao passo que uma combinação melhor de propriedades seja feita. Um material compósito é constituído geralmente de uma fase contínua (matriz), que envolve a 
fase dispersa (carga); e essa combinação pode ser de dois ou mais materiais (CALLISTER, 2002).

A maioria dos compósitos foi criada para melhorar as combinações de características mecânicas como rigidez, dureza e resistência sob temperaturas altas e temperatura ambiente. Resistência à corrosão e baixa massa específica também estão entre as características mais importantes desses materiais.

Os materiais compósitos podem ser divididos em três categorias:

- Compósitos reforçados por partículas: partículas grandes ou reforçadas por dispersão;

- Compósitos reforçados por fibras: fibras contínuas ou descontínuas (curtas). No caso das fibras descontínuas, elas podem ser alinhadas ou orientadas aleatoriamente;

- Compósitos estruturais: compósitos laminados ou painéis sanduíche (CALLISTER, 2002).

Devido às suas características físicas, os materiais compósitos são considerados materiais avançados, tendo aplicações nas áreas de transportes, aeroespacial e subaquática. Outras aplicações incluem decks, construção civil e utensílios em geral (CÂNDIDO e ALMEIDA, 2000).

\subsection{Compatibilização}

As blendas e misturas poliméricas reúnem em um só material as características dos polímeros que as constituem, além de essas misturas ocorrerem por processo de extrusão, apresentando um baixo custo para a sua produção. As blendas e misturas poliméricas são de grande interesse para a indústria automobilística, eletro-eletrônica, embalagens, construção e utensílios domésticos. A maioria das blendas poliméricas possui fases imiscíveis e por esse motivo existe a necessidade do uso de compatibilizantes (KONING, 1998).

A explicação para a incompatibilidade entre materiais poliméricos, como termoplásticos e borrachas, por exemplo, está na alta massa molecular desses materiais e por eles serem termodinamicamente imiscíveis, isto é, as 
fases que se formam apresentam comportamentos diferentes, permanecendo separadas e com pouca adesão entre a matriz e a fase dispersa (SADHAN, 2005).

Sabe-se que a miscibilidade entre polímeros depende do equilíbrio entre entalpia e entropia presentes em sua energia livre de mistura. Haja vista que com moléculas menores, a energia de mistura é alta o suficiente para garantir a sua miscibilidade. Já com polímeros, o que ocorre é diferente, e devido às suas macromoléculas, a entropia é quase nula. Isso faz com que a entalpia seja algo decisivo ao se determinar sua miscibilidade (FINK, 2013; LIVENGOOD, 2003).

A diferença na energia livre de mistura $(\Delta G)$ é determinada abaixo:

$$
\Delta \mathrm{G}=\Delta \mathrm{H}-\mathrm{T} \Delta \mathrm{S}
$$

Onde $\mathrm{H}$ é a entalpia, S é a entropia, e T representa a temperatura.

Para uma mistura espontânea, o valor de $\Delta G$ precisa ser negativo, então:

$$
\Delta \mathrm{H}-\mathrm{T} \Delta \mathrm{S}<0
$$

Isso significa que misturas exotérmicas $(\Delta H<0)$ irão se misturar espontaneamente, enquanto que misturas endotérmicas somente ocorrerão em altas temperaturas (FINK, 2013; LIVENGOOD, 2003).

\subsubsection{Agentes compatibilizantes}

A função dos agentes compatibilizantes na formação da blenda polimérica é de promover melhor adesão entre fases, melhorar a dispersão e diminuir o tamanho das partículas dispersas (KONING, 1998). O objetivo fundamental é produzir um material de estrutura estável com transferência de esforço de uma fase para outra, para que assim possa resistir aos múltiplos esforços nele empregados (SADHAN, 2005).

$\mathrm{Na}$ TAB. 2 vemos os principais compostos compatibilizantes empregados em poliolefinas: 
TABELA 2: Agentes compatibilizantes usados em poliolefinas (FINK, 2013).

\begin{tabular}{|c|c|}
\hline Blendas & Compatibilizantes \\
\hline PEBD/PA6 & $\begin{array}{l}\text { Dietil succinato, metacrilato de glicidila, copolímero de } \\
\text { etileno e ácido acrílico, polietileno graftizado com } \\
\text { anidrido maleico }\end{array}$ \\
\hline PEBD/PET & $\begin{array}{l}\text { Copolímero de etileno-propileno graftizado com } \\
\text { carbamato de metacrilola }\end{array}$ \\
\hline PEBD/amido & Polietileno graftizado com metacrilato de glicidila \\
\hline PEAD/HIPS & $\begin{array}{l}\text { Copolímero em bloco de estireno/etileno- } \\
\text { butileno/estireno }\end{array}$ \\
\hline PEAD/PA12 & Anidrido maleico \\
\hline PEAD/PET & Polietileno graftizado com metacrilato de glicidila \\
\hline PP/PS & $\begin{array}{l}\text { Copolímero tribloco de estireno-butadieno, copolímero } \\
\text { dibloco de estireno-etileno/propileno (SEP) }\end{array}$ \\
\hline PP/PA6 & $\begin{array}{l}\text { Polipropileno graftizado com } \varepsilon \text { - caprolactama e } \\
\text { anidrido maleico, PP modificado com isocianato, }\end{array}$ \\
\hline EPDM/PTT & Borracha de etileno/propileno graftizada (EPM-g-MA) \\
\hline Poliolefinas & Isocianurato de trialila \\
\hline
\end{tabular}

\subsubsection{Metacrilato de glicidila (GMA)}

O metacrilato de glicidila (GMA) possui um grupo reativo epóxi que pode sofrer uma série de reações em dadas condições, por isso tem sido grande o interesse em torno desse material atualmente. Alguns homo e copolímeros à base de GMA têm variadas aplicações práticas, como de modificadores de superfície e agentes compatibilizantes para misturas poliméricas. O GMA possui a carbonila- $\alpha, \beta$-insaturada, que promove a reticulação ou uma forte adesão interfacial (DENG, 2008; DEVI, 2012).

\subsection{Trabalhos Anteriores com PEAD e Borracha EPDM}

São poucos os trabalhos encontrados na literatura que tratam da combinação dos materiais PEAD e EPDM. Alguns desses trabalhos são citados a seguir: 
Stelescu et al (2013) estudaram as propriedades estruturais de blendas formadas por polietileno de alta densidade com a borracha de EPDM. A blenda foi obtida em estado fundido em um misturador industrial com rotação de $80 \mathrm{rpm}$ e temperatura de $170 \stackrel{\circ}{ } \mathrm{C}$. Também ocorreu a compatibilização dos componentes da blenda com o polietileno enxertado com anidrido maleico (PE-g-MA), ou por vulcanização dinâmica usando resinas fenólicas, com o objetivo de se obter melhores propriedades mecânicas. Os resultados indicaram que o composto vulcanizado apresentou um grau menor de cristalinidade. Tensão na ruptura e dureza aumentaram significativamente para os compostos contendo o agente compatibilizante.

Cañavate et al (2011) estudaram formulações para termoplásticos vulcanizados (TPV) baseados em polietileno de alta densidade, monômero de etileno-propileno-dieno, e pó de borracha inservível (GTR - Ground Tire Rubber). A vulcanização foi realizada por um novo peróxido desenvolvido para resistir a altas temperaturas e um peróxido padrão. $\mathrm{O}$ objetivo deste estudo foi aperfeiçoar a formulação para incluir o GTR, ainda mantendo um bom balanceamento das propriedades finais do material TPV. As análises de termogravimetria (TG) e calorimetria exploratória diferencial (DSC) indicaram um alto grau de reticulação e boa adesão entre a fase de borracha com a matriz. Um compósito contendo a combinação de peróxidos e as proporções de 40/30/30 de PEAD, EPDM e GTR foi o que mostrou um bom equilíbrio de características, no que diz respeito a propriedades mecânicas, reticulação e adesão entre fases.

Céspedes et al (2013) produziram termoplásticos elastoméricos baseados em polietileno de alta densidade, terpolímero de etileno-propilenodieno, e pó de borracha inservível (GTR) vulcanizados por vulcanização dinâmica com peróxido de dicumila (DCP). A blenda polimérica foi composta de $40 \%$ de PEAD, 30 \% EPDM e $30 \%$ de GTR, e a concentração de DCP variou de 0,3 a 3,6 partes por cem partes de borracha (phr). Os resultados mostraram a diminuição no módulo de Young das blendas e diminuição na cristalinidade do PEAD quando o conteúdo de DCP foi maior que 1,8 phr. Também foi observado que o DCP promoveu a reticulação das blendas e as melhores propriedades apresentadas foram com $1,5 \%$ de DCP. 


\subsection{Radiação lonizante}

Radiação ionizante é qualquer radiação constituída por partículas ou fótons capaz de produzir ou gerar íons. A radiação ionizante pode ser produzida naturalmente ou por processos criados pelo homem. Somente os comprimentos de onda mais curtos do espectro eletromagnético são capazes de interagir com a matéria produzindo íons (FINUCANE, 1998).

A ionização da matéria pode ocorrer direta ou indiretamente. A forma direta ocorre por partículas com carga eletrônica (ex: elétrons, pósitrons, prótons, partículas alfa, etc.), e por fótons e/ou partículas de energia cinética suficientemente alta para se produzir ionização por colisões com átomos e/ou moléculas presentes no meio. Na forma indireta, ao liberar uma ou mais partículas de "ionização direta" da matéria em que essas partículas colidiram ou interagiram, e por iniciarem-se transições nucleares ou transformações, como por exemplo, o decaimento de elementos radioativos em outros elementos com menor energia (FINUCANE, 1998).

$\mathrm{Na}$ interação da radiação ionizante com a matéria, a dose absorvida é medida em "Gray" (Gy), onde 1 Gy equivale a 1 Joule de qualquer tipo de radiação ionizante por $1 \mathrm{~kg}$ de matéria. Raios $X$ e radiação gama possuem valores diferentes para a dose absorvida (SHARPATYI, 2006).

\subsubsection{Efeitos da radiação ionizante em polímeros}

A exposição de materiais poliméricos à radiação ionizante provoca inicialmente uma ionização ou excitação de suas moléculas, favorecendo assim as reações químicas. O produto final é um material reticulado ou degradado, isto é, as reações que ocorrem, ou causam a cisão das cadeias poliméricas (degradação), ou formam a estrutura tridimensional das ligações cruzadas no processo de reticulação. Neste caso, é importante informar que degradação e reticulação são processos concorrentes, pois ocorrem ao mesmo tempo, e o grau de reticulação ou degradação é proporcional à dose de radiação que é aplicada. As transformações causadas pelo processo de irradiação afetam as características físicas, químicas e mecânicas do material (CHARLESBY, 1960). 


\section{MATERIAIS E MÉTODOS}

\subsection{Materiais}

\subsubsection{PEAD virgem e PEAD reprocessado}

Para este trabalho, foi utilizado o polietileno de alta densidade virgem (HD7255LSL Braskem), com densidade 0,954 g/ $\mathrm{cm}^{3}$.

O material reciclado foi obtido a partir da extrusão do PEAD virgem; cada ciclo de extrusão definiu cada reprocessamento: no primeiro ciclo de extrusão obteve-se o primeiro reprocessamento do PEAD, e assim sucessivamente. Sendo assim, o PEAD reprocessado foi obtido a partir do que se chama reciclagem primária industrial. A metodologia está descrita no item 4.2.1.

4.1.2 Borracha EPDM sem tratamento térmico (ST) e com tratamento térmico (TT)

A borracha de EPDM vulcanizada foi gentilmente doada pela empresa Edra Eco Sistemas, Ltda. na forma de aparas de perfis extrusados que são fabricados por essa empresa e destinados a vedações na área de saneamento e instalações industriais, cuja composição qualitativa informada é: EPDM, óxido de Zinco, enxofre, óleo parafínico e cargas reforçantes.

Esse material foi fragmentado manualmente em ralador metálico. Os fragmentos usados possuiam tamanho de 35 mesh. A meta foi obter uma dada fragmentação que possibilitasse a extrusão.

A fim de avaliar a extrusão do compósito, utilizou-se também a borracha após ser submetida a um tratamento térmico. $O$ tratamento térmico possibilita diminuir os teores de alguns componentes do material de partida, como o óleo mineral e também degradar as ligações de enxofre formadas durante a seu processo de vulcanização.

Os tipos de tratamento térmico foram: irradiação da borracha sob temperatura elevada e envelhecimento térmico. A metodologia está descrita no item 4.2.2. 


\subsection{Métodos}

\subsubsection{Obtenção do PEAD reprocessado}

$O$ reprocessamento consistiu em extrudar o PEAD virgem em uma extrusora dupla rosca, modelo AX DR16: 40, da marca AX Plásticos (Laboratório de Processos de Plásticos - CTR/IPEN/CNEN-SP), representada na FIG. 3.

Os perfis de temperatura utilizados nas zonas da máquina (seis zonas e o cabeçote) estão descritos na TAB. 3. A rotação do alimentador foi de 9 rpm e da dupla rosca foi de $60 \mathrm{rpm}$.

TABELA 3: Perfis de temperatura para extrusão do PEAD.

\begin{tabular}{cccccccc}
\hline Zona & 1 & 2 & 3 & 4 & 5 & 6 & Cabeçote \\
\hline $\begin{array}{c}\text { Temperatura } \\
\left({ }^{\circ} \mathrm{C}\right)\end{array}$ & 90 & 120 & 175 & 180 & 185 & 190 & 190 \\
\hline
\end{tabular}

As etapas subsequentes consistiram em utilizar o produto do reprocessamento anterior, sequencialmente até o $19^{\circ}$ reprocessamento (ciclo). O vigésimo reprocessamento se deu por injeção em moldes de corpos de prova do material reprocessado.

Neste trabalho o processo de extrusão foi utilizado somente como uma forma de obter o reprocessamento primário do termoplástico, sem considerar e ajustar parâmetros reológicos do material original em cada etapa do reprocessamento.

Em determinados estágios de reprocessamento $\left(5^{\circ}, 10^{\circ}, 15^{\circ}\right.$ e $\left.1^{\circ}\right)$, as amostras de PEAD foram caracterizadas por espectrometria na região do infravermelho (FTIR) e por termogravimetria (TG). 


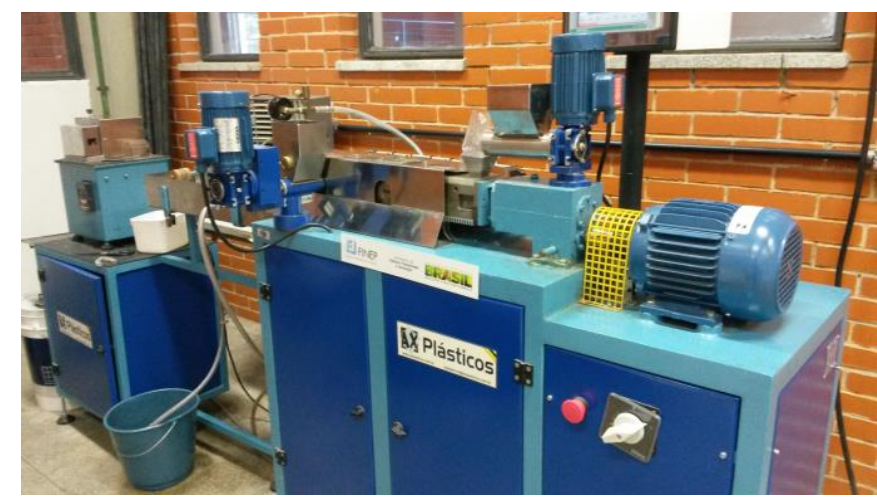

FIGURA 3: Extrusora de plásticos.

\subsubsection{Borracha EPDM com tratamento térmico}

Foram aplicados dois tipos de tratamento térmico na borracha EPDM vulcanizada:

\subsubsection{Envelhecimento térmico em estufa}

As aparas da borracha de EPDM foram mantidas sob aquecimento contínuo em uma estufa (modelo TE-395, marca Tecnal) por períodos de 7, 14 e 21 dias, sob temperaturas de $50 \stackrel{\circ}{\circ}$ e $100 \stackrel{\circ}{\circ}$; e após cada período de envelhecimento, o material foi caracterizado por termogravimetria.

\subsubsection{Irradiação sob temperatura elevada}

Fragmentos e fatias de $4 \mathrm{~mm}$ de borracha EPDM vulcanizada foram dispostas em placas de Petri e colocadas em uma câmara de irradiação com aquecimento simultâneo. A temperatura de $160{ }^{\circ} \mathrm{C}$ foi a utilizada durante esse processo.

A irradiação foi realizada em um acelerador de elétrons JOB 188 Dynamitron ${ }^{\circledR}$, de $1,5 \mathrm{MeV}$ de energia, cuja intensidade do feixe foi de $45 \mathrm{~mA}$, potência $37,5 \mathrm{~kW}$ e com faixa de varredura de $50 \mathrm{~cm}$ a $120 \mathrm{~cm}$. As doses absorvidas foram de 150 kGy a 800 kGy na taxa de dose de 22,4 kGy/s.

Após esse processo, as amostras foram caracterizadas por termogravimetria. 


\subsubsection{Obtenção dos compósitos PEAD/EPDM reprocessados}

Os compósitos de PEAD virgem e PEAD reprocessado com EPDM vulcanizado, com e sem tratamento térmico também foram obtidos por extrusão na extrusora dupla rosca.

O PEAD foi usado como matriz principal (maior proporção) e o EPDM foi usado como componente carga, nas proporções de $1 \%$ e $5 \%$.

O processo de extrusão foi realizado na ausência e na presença de agente compatibilizante. Como compatibilizante, foram utilizados o peróxido de dicumila, o anidrido maleico e o metacrilato de glicidila. As concentrações utilizadas foram $0,25 \%, 0,5 \%$ e $1 \%$.

A forma de misturar o agente compatibilizante é diferente em cada caso:

- O peróxido de dicumila (DCP) foi usado diretamente na mistura do PEAD com o EPDM e em seguida, colocados no funil alimentador da extrusora;

- O anidrido maléico (MA) em uma dada concentração foi disperso em acetona; nesse caso há a necessidade de se colocar o iniciador, que foi o peróxido de dicumila, colocado em uma proporção de uma parte para duas partes de MA. O PEAD foi deixado em contato com essa mistura até a evaporação do solvente, para que o compatibilizante adsorvesse em todo o termoplástico. Em seguida o PEAD com o compatibilizante foi misturado ao EPDM e então essa mistura foi levada ao misturador da extrusora. Essa metodologia foi baseada no trabalho de Li et al (2003);

- O metacrilato de glicidila (GMA) foi primeiramente misturado aos fragmentos da borracha EPDM e em seguida, adicionou-se o PEAD. Essa mistura foi finalmente enviada ao funil alimentador da extrusora. Essa metodologia foi baseada no estudo de Ferreira et al (2014).

Após a extrusão, os materiais foram injetados em formato de corpos de prova para ensaios mecânicos, segundo as normas ASTM D 638 e ASTM D 256 (FIG. 4). 
O processo de injeção foi realizado em uma injetora da marca Demag Ergotech, modelo 35/115 (Departamento de Engenharia Metalúrgica e de Materiais, PMT - Escola Politécnica da USP/SP).

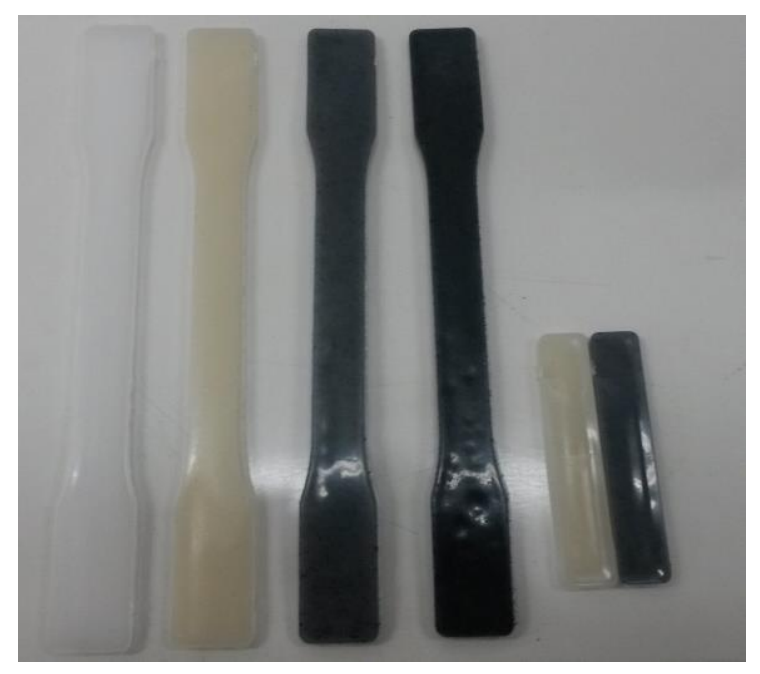

FIGURA 4: Corpos de prova dos materiais e compósitos utilizados neste trabalho.

Da esquerda para a direita: tração: PEAD virgem e reprocessado, e compósitos de PEAD virgem com $1 \%$ e $5 \%$ de EPDM; e impacto: PEAD reprocessado e compósito de PEAD virgem com $1 \%$ de EPDM.

\subsubsection{Irradiação dos materiais}

Parte dos corpos de prova injetados foi submetida ao processo de irradiação por feixe de elétrons. As doses absorvidas foram de 50 kGy e 100 kGy na taxa de dose de 22,4 kGy/s. O processo ocorreu no acelerador de elétrons, modelo JOB 188, da marca Dynamitron $\AA$, com energia de 1,5 MeV e corrente de 2,81 mA (Centro de Tecnologia das Radiações - CTR-IPEN-CNEN/SP).

\subsection{Caracterização dos Materiais}

As amostras produzidas neste trabalho foram caracterizadas por análise térmica: termogravimetria (TG) e calorimetria exploratória diferencial (DSC); espectrometria no infravermelho (FTIR); análise mecânica: ensaios de tração, dureza (Shore D) e impacto Izod, e microscopia eletrônica de varredura (MEV). 
4.3.1 Espectrometria no Infravermelho por Transformada de Fourier (FTIR)

A espectrometria no infravermelho permite identificar os grupos funcionais que constituem as moléculas dos materiais analisados a partir da obtenção de espectros provenientes da interação da radiação eletromagnética com a matéria (CANEVAROLO JR, 2004).

A técnica foi realizada no modo transmissão, a partir da prensagem dos fragmentos dos corpos de prova injetados (FIG. 5), o que garantiu a passagem da radiação infravermelha.

Os espectros de FTIR foram obtidos no equipamento espectrômetro FTIR Perkin-Elmer, modelo Spectrum 100 (CTR-IPEN-CNEN-SP), no modo de transmitância, na faixa de frequência do infravermelho médio $\left(4.000\right.$ a $\left.400 \mathrm{~cm}^{-1}\right)$, com resolução de $4 \mathrm{~cm}^{-1}$ e após 16 varreduras.

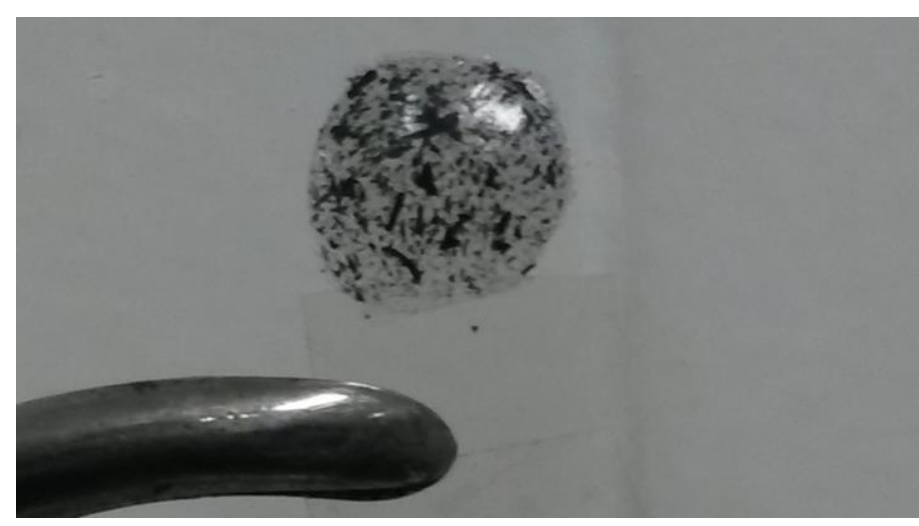

FIGURA 5: Amostra prensada submetida à técnica de espectrometria FTIR.

\subsubsection{Calorimetria Exploratória Diferencial (DSC)}

Na técnica de DSC a amostra e a referência são mantidas em um ambiente isotérmico e a partir disso, sofrem variações controladas de temperatura durante um dado período de tempo, onde são medidas as temperaturas e o fluxo de calor de acordo com as transições físicas. A técnica de DSC é muito utilizada para caracterizar materiais por fornecer dados como transição vítrea, temperaturas de fusão e cristalização, calor específico, oxidação, pureza, estabilidade térmica, grau de cura e cinética de reação (MACHADO e MATOS, 2004; MOTHÉ e AZEVEDO, 2002).

Os ensaios foram realizados em um calorímetro de varredura diferencial marca Perkin-Elmer, modelo DSC 6000 (CTR-IPEN/CNEN/SP), sob 
fluxo de gás nitrogênio (50 $\mathrm{ml} / \mathrm{min})$, nas seguintes etapas de aquecimento e esfriamento a $10^{\circ} \mathrm{C} / \mathrm{min}$ :

- $50^{\circ} \mathrm{C}$ a $-30{ }^{\circ} \mathrm{C}$;

- $-30^{\circ} \mathrm{C}$ a $180^{\circ} \mathrm{C}$;

- $180^{\circ} \mathrm{C}$ a $50^{\circ} \mathrm{C}$.

A massa das amostras foi de aproximadamente $12 \mathrm{mg}$ e os ensaios foram feitos em triplicata.

Essa técnica permitiu verificar as transições de fase (fusão e cristalização) das amostras e determinar a temperatura de fusão e de cristalização, bem como o grau de cristalinidade, de acordo com a equação:

$$
X_{c}=\frac{\Delta H_{f}}{\Delta H_{0}} \times 100
$$

Onde $\Delta \mathrm{H}_{f}$ é a variação de entalpia da amostra e $\Delta \mathrm{H}_{0}$ é a variação de entalpia de fusão do polietileno $100 \%$ cristalino assumido como $290 \mathrm{~J} / \mathrm{g}$ (SNYDER, 1980).

\subsubsection{Termogravimetria (TG)}

$\mathrm{Na}$ termogravimetria avalia-se a variação de massa (perda ou ganho) em função de temperatura e/ou tempo quando a amostra é submetida a uma temperatura controlada (MATOS e MACHADO, 2004; MOTHÉ e AZEVEDO, 2002).

A termogravimetria foi realizada em um equipamento da marca TA Instruments (FIG. 6), modelo Q600 STD (CTR/IPEN/CNEN-SP). Neste equipamento é possível obter dados de DTA (calor específico/entalpia) simultaneamente durante a realização da análise.

O comportamento de degradação térmica foi verificado entre as temperaturas ambiente (em torno de $25^{\circ} \mathrm{C}$ ) e $800^{\circ} \mathrm{C}$, utilizando-se cadinhos de 
platina, aplicando-se uma taxa de aquecimento de $20^{\circ} \mathrm{C} / \mathrm{min}$ e sob o fluxo de ar comprimido de $100 \mathrm{ml} / \mathrm{min}$. As análises foram realizadas em triplicata. As amostras não sofreram nenhum tratamento prévio ao ensaio, exceto a amostra de EPDM puro (Keltan® 5508), que foi deixada em contato em uma solução $30 \%$ de clorofórmio em metanol durante 60 minutos sem agitação.

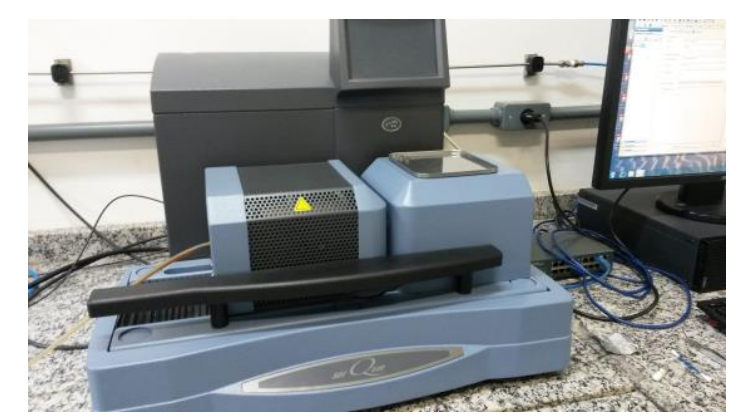

FIGURA 6: Equipamento de termogravimetria - TA Instruments.

\subsubsection{Ensaios mecânicos}

\subsubsection{Ensaio de tração}

Este teste é baseado na norma ASTM D 638 e avalia as propriedades de tensão do material polimérico submetido à tração. $O$ ensaio de tração permite avaliar o desempenho mecânico de um polímero, como módulo de Young ou de elasticidade; tensão e deformação no escoamento; tensão máxima; tensão e deformação na ruptura, e tenacidade (CANEVAROLO, 2010).

Os ensaios foram realizados em uma máquina universal de ensaios mecânicos (FIG. 7), da marca Instron, modelo 5755 (CTR/IPEN/CNEN-SP). Cada medida contou com cinco repetições para cada amostra, conforme requisito da norma. 


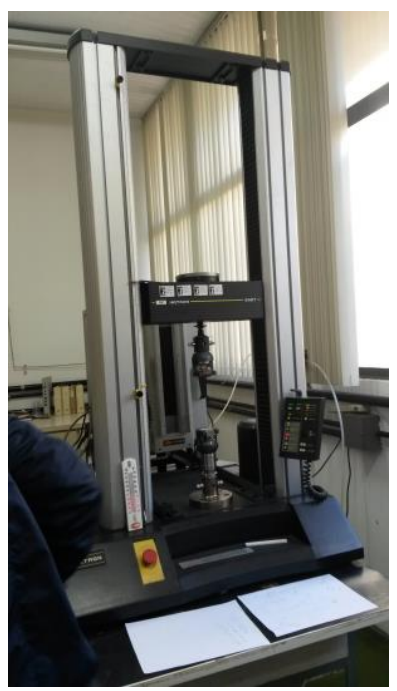

FIGURA 7: Máquina universal de ensaios - medidas de tração-deformação.

\subsubsection{Ensaio de impacto Izod}

O ensaio de impacto Izod foi realizado segundo a norma ASTM D 256. Este teste avalia a resistência mecânica de materiais plásticos por meio de absorção de energia de impacto.

Neste teste (Izod), as amostras do material devem possuir um entalhe no meio de sua extensão para facilitar sua ruptura durante o teste e evitar que o material apenas sofra uma deformação. A amostra é então posicionada na vertical, com metade de sua extensão presa no equipamento e com metade do entalhe livre e em direção ao pêndulo, como se observa na FIG. 8. Essa posição está na trajetória do pêndulo presente no equipamento. Finalmente, para executar o teste, basta soltar o pêndulo para que ele atinja a amostra.

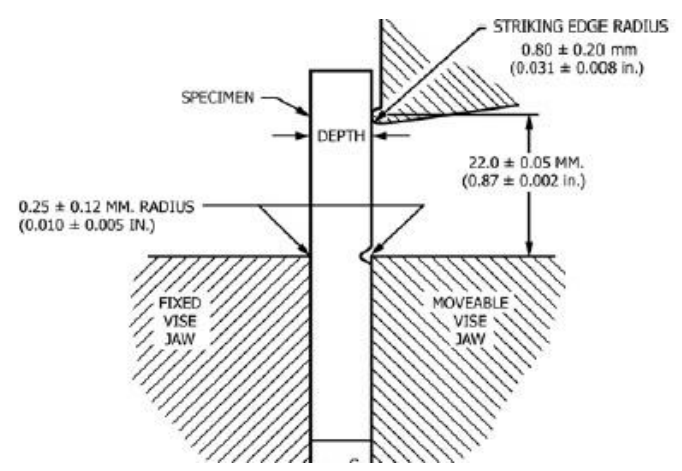

FIGURA 8: Corpo de prova para teste de impacto, posicionado no equipamento (ASTM D 256). 
Os testes de resistência ao impacto foram realizados em um equipamento Tinius Olsen (FIG. 9), modelo 892 para ensaios de impacto (laboratório de Engenharia de Materiais da Universidade Presbiteriana Mackenzie $-\mathrm{SP})$.

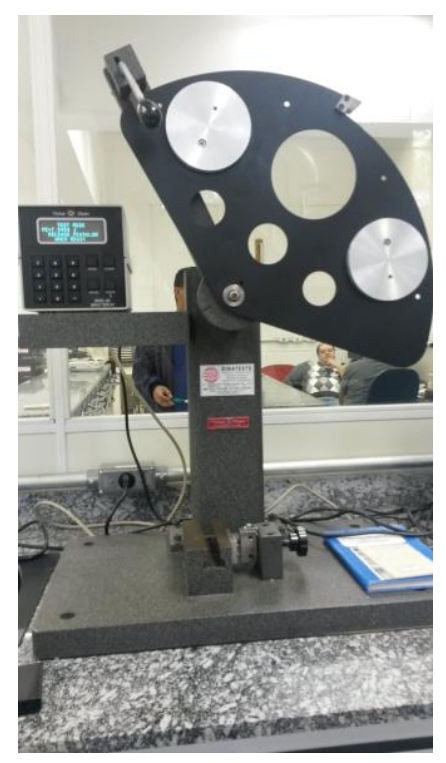

FIGURA 9: Equipamento de ensaios de resistência ao impacto.

Os parâmetros da máquina no momento dos testes foram:

- Energia potencial do pêndulo: 7,5454 J;

- Peso do pêndulo: 1,264 kg;

- Altura do pêndulo: $608,717 \mathrm{~mm}$;

- Raio do pêndulo: $334,925 \mathrm{~mm}$.

Cada medida foi o resultado da média de 5 replicatas para cada tipo de amostra.

\subsubsection{Ensaio de dureza (Shore D)}

Devido à natureza termoplástica e elastomérica das amostras do compósito (PEAD e EPDM), os testes de dureza foram executados de acordo com a norma ASTM D 2240, que, entre outros, especifica as condições de teste de dureza Shore D. As amostras da borracha EPDM foram analisadas pelo teste de dureza Shore A. 
O equipamento usado foi um durômetro da marca Instron, (CTR-IPENCNEN/SP), com uma ponteira (ou agulha) específica para o teste. A amostra a ser testada é posicionada na horizontal, em uma superfície plana. Este teste ocorre com a penetração da ponteira ao ser forçada contra a amostra, em condições específicas. O grau de dureza da ponteira é inversamente proporcional ao comportamento viscoelástico e módulo de elasticidade do material. Cada medida contou com cinco repetições para cada amostra.

\subsubsection{Microscopia Eletrônica de Varredura (MEV)}

Com a microscopia eletrônica de varredura é possível estudar a estrutura superficial e realizar análises qualitativas e semi-quantitativas (através do EDS presente no equipamento) das amostras. Materiais com baixa condutividade, como grande parte dos polímeros, necessitam de um revestimento condutivo para a realização do ensaio, para que isso evite o acúmulo de cargas negativas na amostra (CANEVAROLO, 2004).

A microscopia foi realizada em amostras sem revestimento condutivo e as imagens foram obtidas em um microscópio eletrônico de varredura da marca Hitachi, modelo T3000 TABLETOP (Centro de Ciência e Tecnologia de Materiais - CCTM/IPEN/CNEN/SP). 


\section{RESULTADOS E DISCUSSÃO}

\subsection{Tratamento térmico da borracha EPDM vulcanizada}

Nesse estudo considerou-se que a borracha vulcanizada deveria passar por um processo de desvulcanização, de modo a quebrar o arranjo molecular tridimensional obtido por esse processo, para que fosse melhor reprocessada por extrusão. Sendo assim, realizaram-se dois tipos de processamento térmico: a) irradiação por feixe de elétrons com aquecimento simultâneo $\left(160^{\circ} \mathrm{C}\right)$ e b) envelhecimento térmico da borracha.

\subsubsection{Irradiação com aquecimento simultâneo}

Após a irradiação por feixe de elétrons sob temperatura de $160{ }^{\circ} \mathrm{C}$, as amostras da borracha EPDM foram submetidas ao teste de dureza Shore A, cujos resultados estão apresentados na FIG. 10, onde se observa redução desse parâmetro na amostra irradiada em 400 kGy em cerca de 30 unidades em relação ao material de partida não submetido a tal processo, o que caracteriza uma modificação na estrutura desse material. Esse comportamento não foi verificado nas demais doses absorvidas.

Irradiação Feixe de Elétrons sob temperatura $\quad\left(160{ }^{\circ} \mathrm{C}\right)$

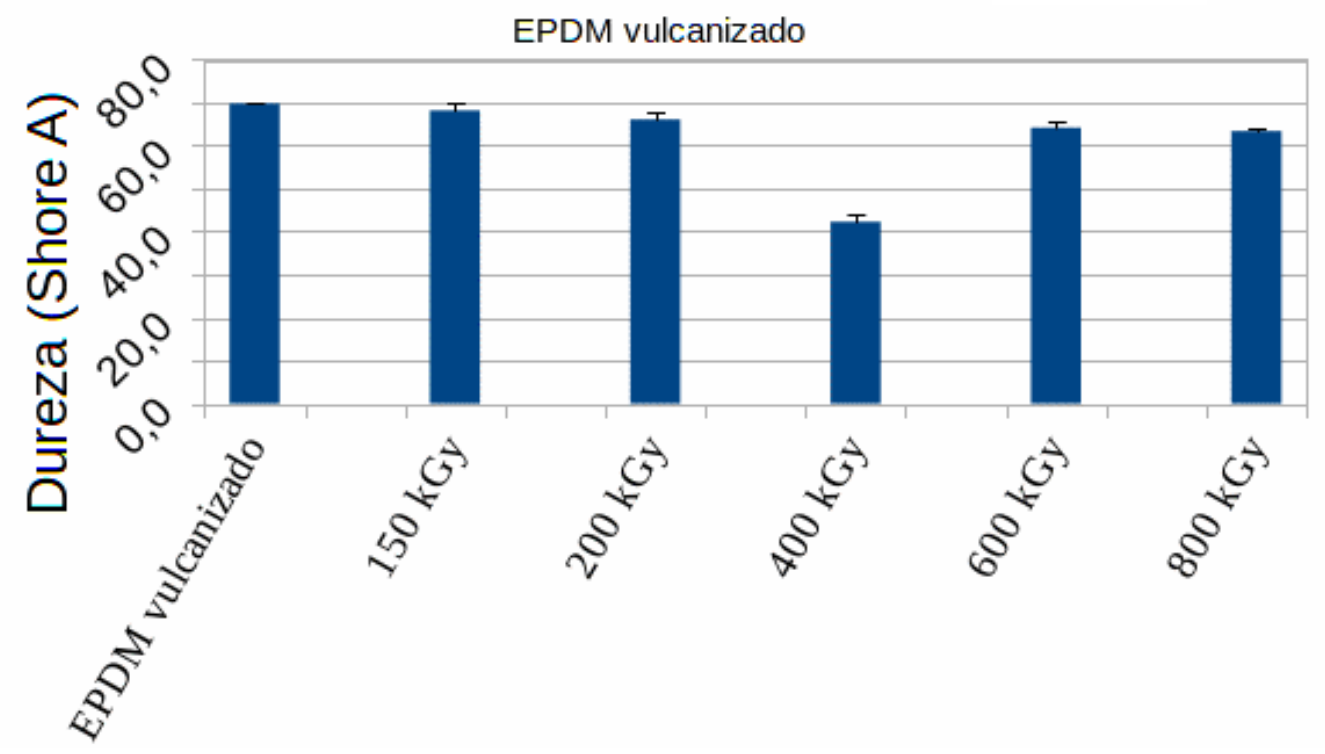

FIGURA 10: Dureza Shore da amostra de EPDM original e irradiado. 
O EPDM puro (não vulcanizado) degrada-se a partir de $420{ }^{\circ} \mathrm{C}$ e esse processo atinge seu pico em $479{ }^{\circ} \mathrm{C}$ em um único evento, como mostra a análise termogravimétrica desse material (FIG. 11).

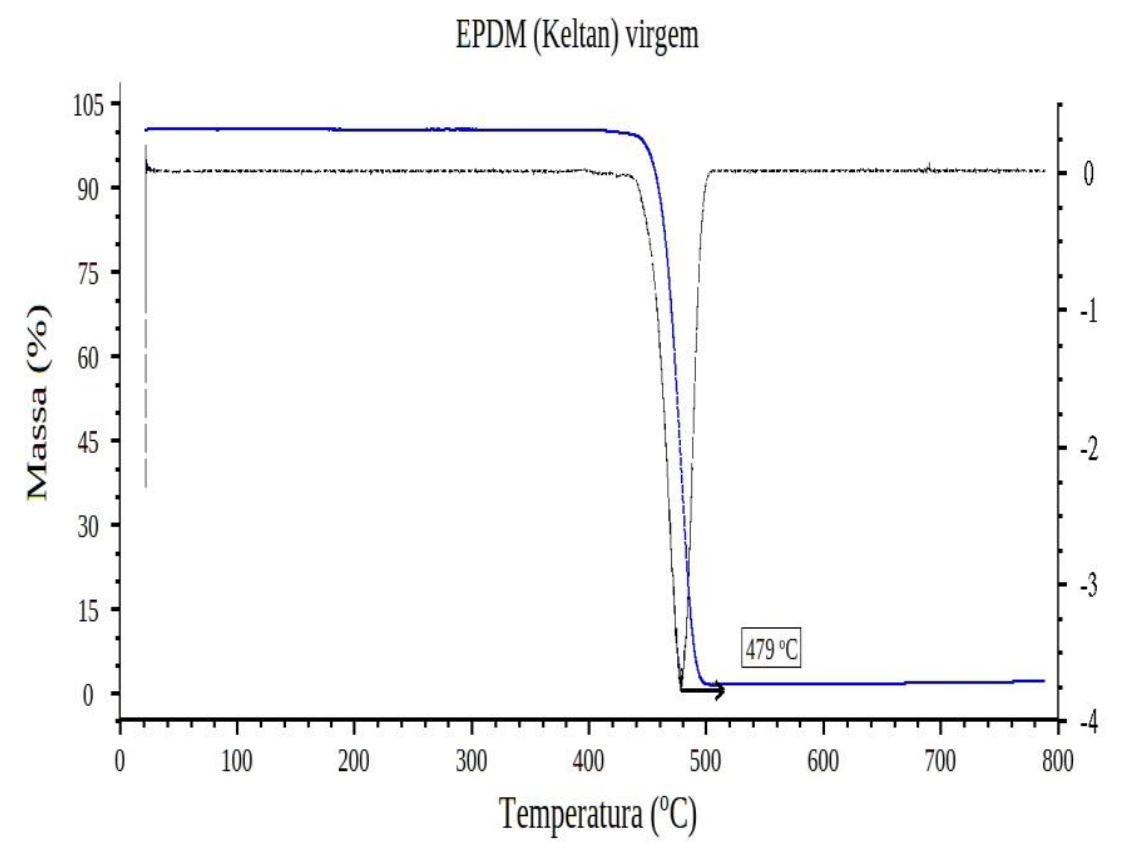

FIGURA 11: Curva termogravimétrica do EPDM puro e a derivada primeira dessa curva (DTG).

A termogravimetria das amostras de EPDM vulcanizado não irradiado (FIG. 12) mostra quatro estágios consecutivos de degradação, onde o primeiro entre $200{ }^{\circ} \mathrm{C}$ e $350^{\circ} \mathrm{C}$ (pico em $308{ }^{\circ} \mathrm{C}$ ) se deve à degradação de óleos. De acordo com BHOWMICK e STEPHENS (2001), o uso desses óleos favorece o processamento garantindo um bom acabamento da superfície final e promove o processo de vulcanização. Outra etapa de degradação é localizada aproximadamente entre $350^{\circ} \mathrm{C}$ e $500^{\circ} \mathrm{C}$ (pico em $471^{\circ} \mathrm{C}$ ) é relativa ao material orgânico referente à fração de EPDM elastômero usado na composição (PISTOR, 2010). O terceiro evento refere-se à cisão das ligações de enxofre ocorre entre $500 \stackrel{\circ}{\circ}$ e $550 \stackrel{\circ}{\circ}$ (pico em $521^{\circ} \mathrm{C}$ ). Outro fenômeno que pode ser observado é a degradação relativa à combustão de negro de fumo e do restante do material carbonáceo entre $550 \stackrel{\circ}{\circ}$ e $650 \stackrel{\circ}{C}$ (pico em $641^{\circ} \mathrm{C}$ ). 


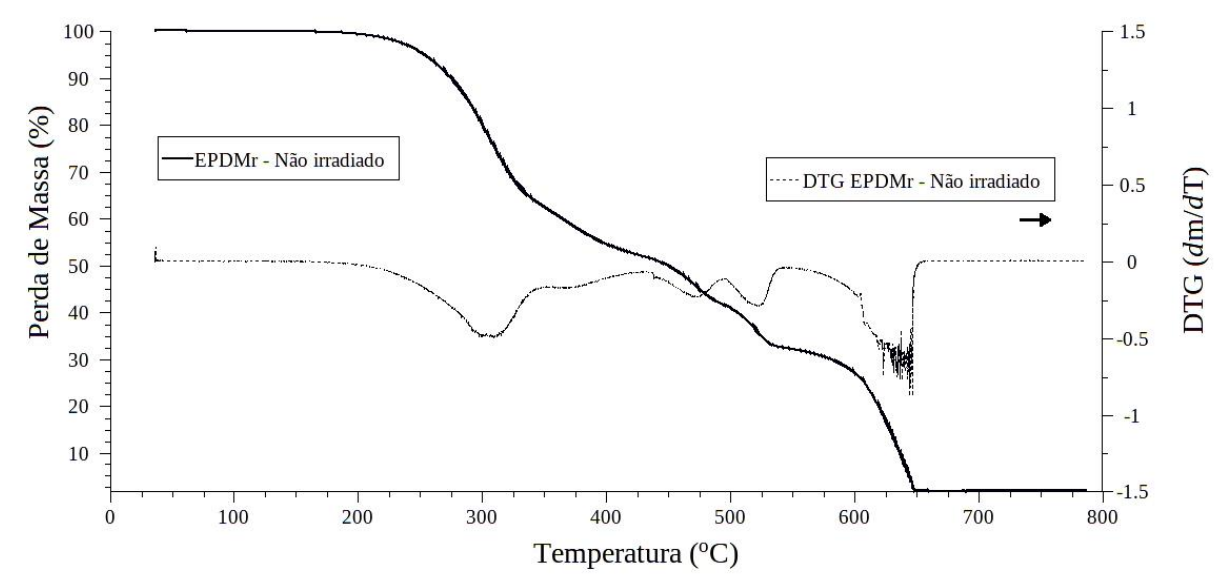

FIGURA 12: EPDM vulcanizado não irradiado - curvas TG e DTG.

O comportamento da degradação térmica da borracha EPDM vulcanizada e submetida à irradiação com aquecimento simultâneo a $160 \stackrel{\circ}{\circ} \mathrm{e}$ nas doses de 200 kGy a 800 kGy é mostrado na FIG. 13. O evento de degradação dos óleos no material irradiado em 200 kGy (FIG. 13a), ocorre em uma temperatura mais alta $\left(535^{\circ} \mathrm{C}\right)$ se comparada à amostra original de EPDM vulcanizado, além disso, observa-se que o pico da DTG para esse evento apresenta baixa amplitude, sugerindo que a fração de óleo que é degradada é menor nessas condições; o evento relativo à cisão das ligações de enxofre acontece a uma temperatura mais baixa $\left(507^{\circ} \mathrm{C}\right)$ e o seu pico de amplitude DTG é menor, sugerindo que há a degradação das ligações cruzadas de enxofre. Em $400 \mathrm{kGy}$, somente o evento atribuído às ligações de enxofre desaparece, o que sugere a desvulcanização do material nessas condições de dose e temperatura. Em 800 kGy, estas mesmas características estão presentes, mas é observado um alargamento do pico de amplitude de DTG relativo à fração de EPDM, sugerindo um possível processo de reticulação da borracha nessas condições. 
a)

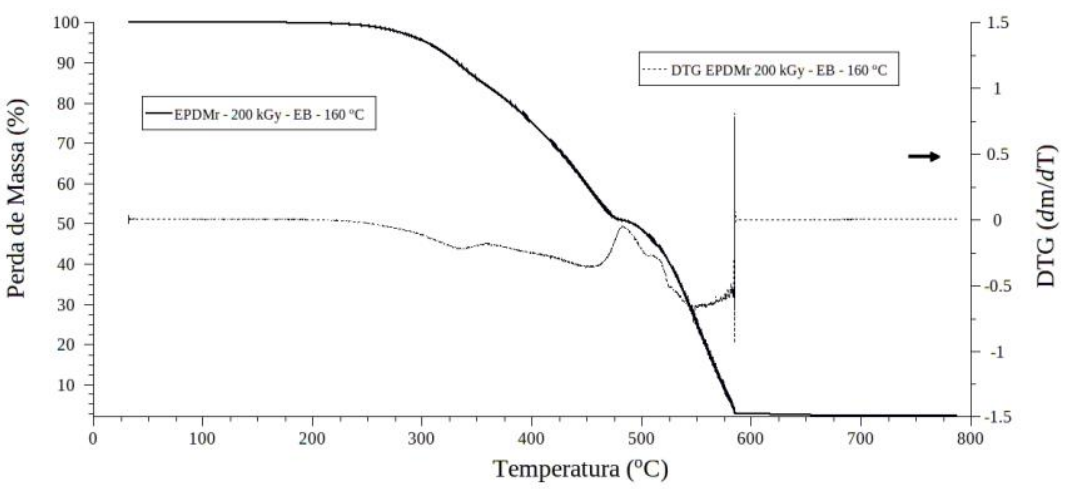

b)

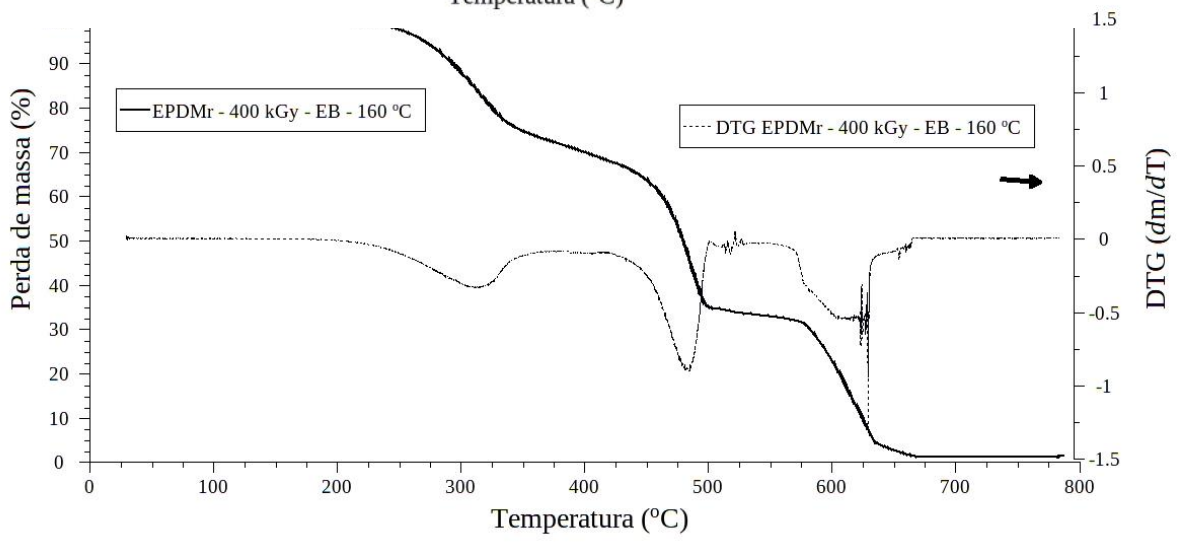

C)

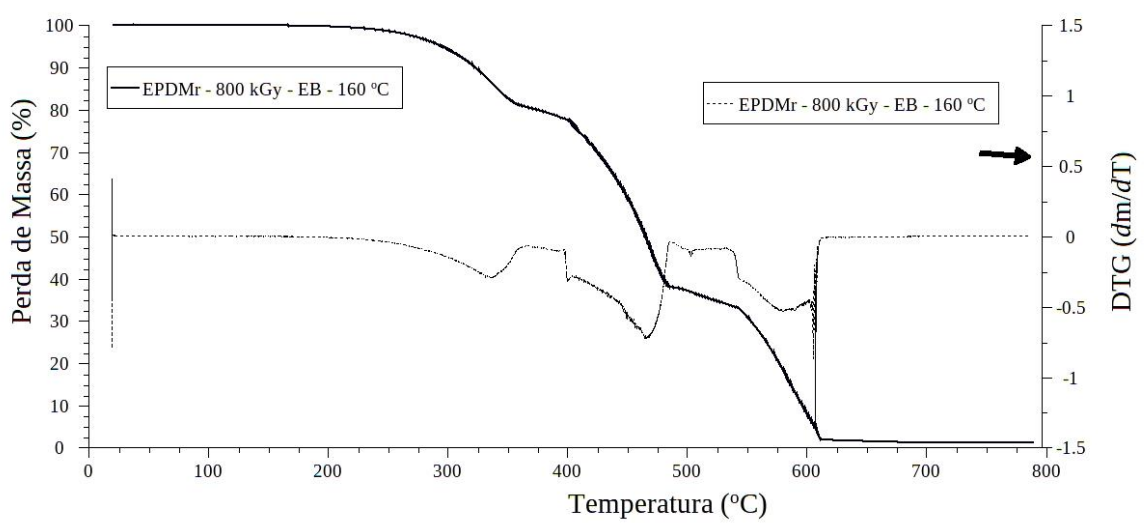

FIGURA 13: Termogravimetria das amostras de borracha EPDM irradiada em feixe de elétrons: a) 200 kGy, b) 400 kGy e c) 800 kGy.

5.1.2 Envelhecimento térmico da borracha EPDM

O comportamento de degradação térmica da borracha EPDM submetida à temperatura de $100^{\circ} \mathrm{C}$ em 7 dias (FIG. 14a), apresenta somente dois estágios de degradação: aquele que se refere à borracha e o que se refere às 
demais substâncias presentes na borracha original, nessas condições ocorre a quebra das ligações de enxofre responsáveis pela vulcanização do produto.

a)

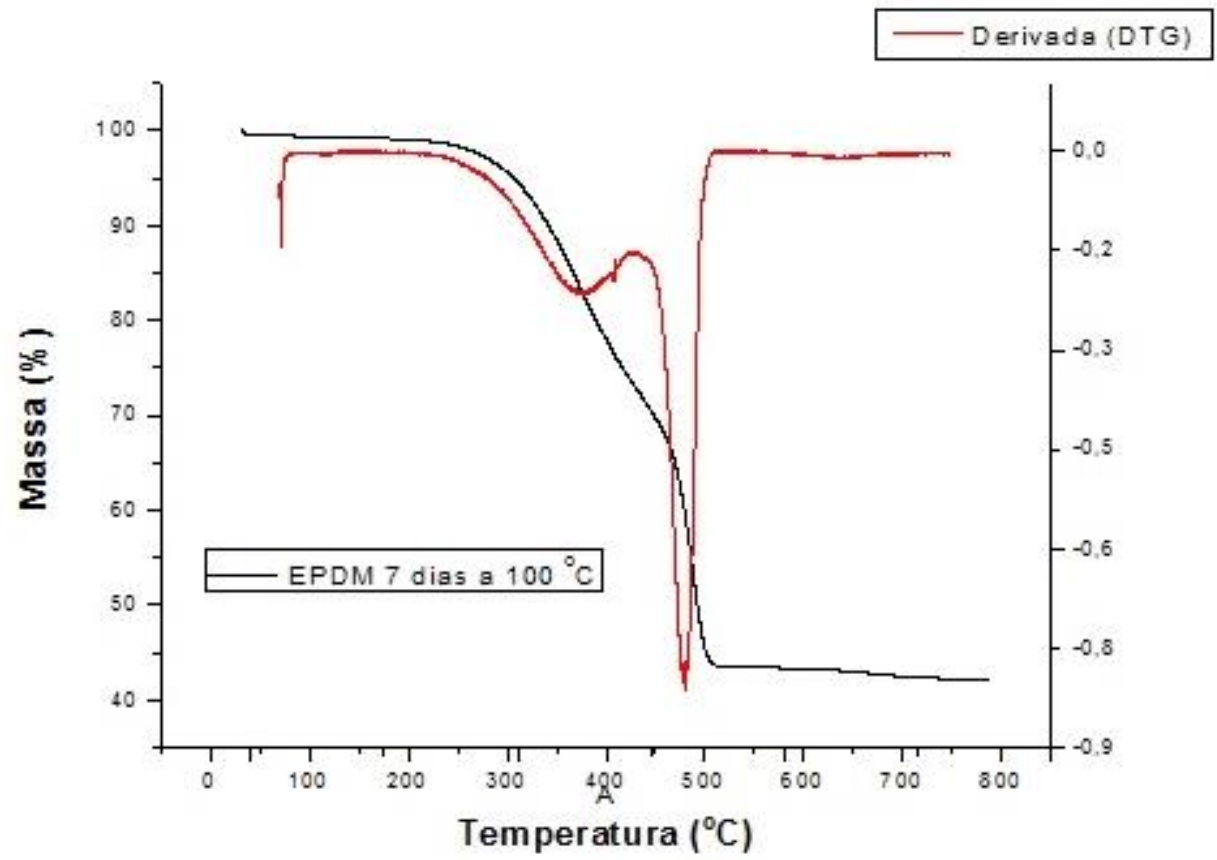

b)

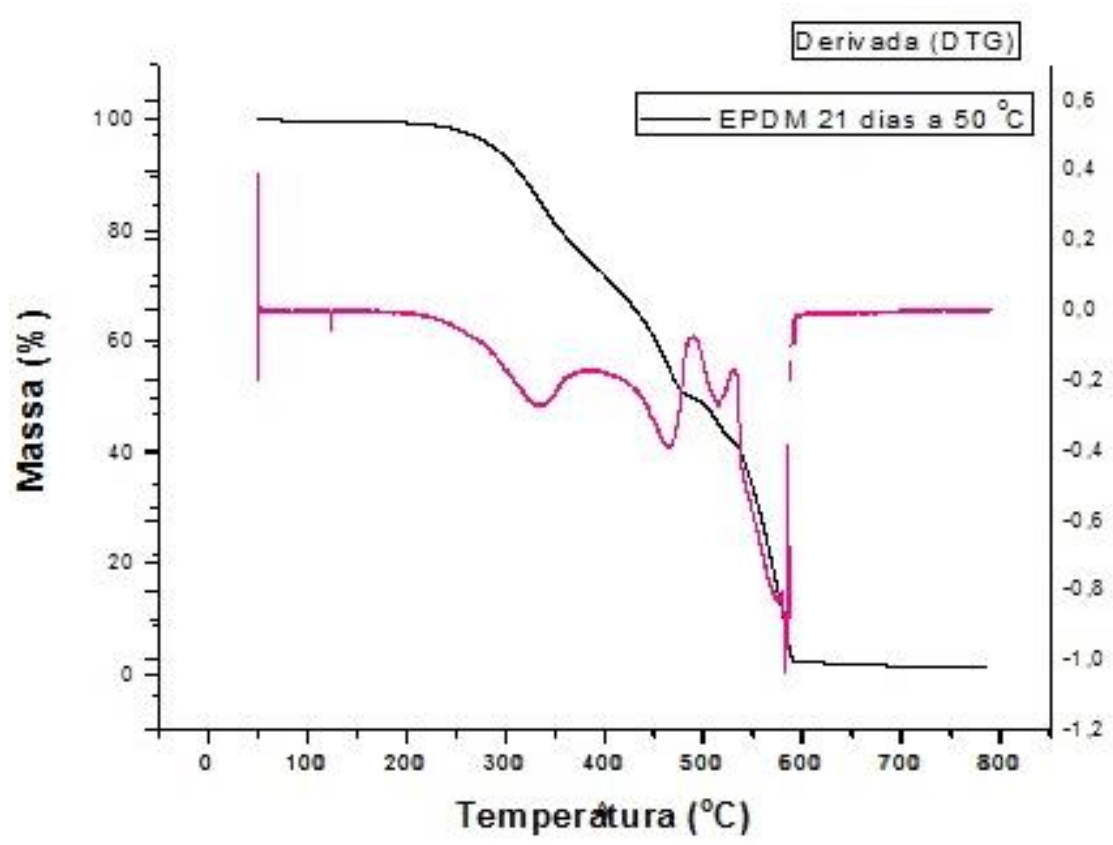

FIGURA 14: Degradação térmica das amostras de borracha EPDM envelhecidas:

a) 7 dias a $100^{\circ} \mathrm{C}$; b) 21 dias a $50^{\circ} \mathrm{C}$ e (continua). 
c)

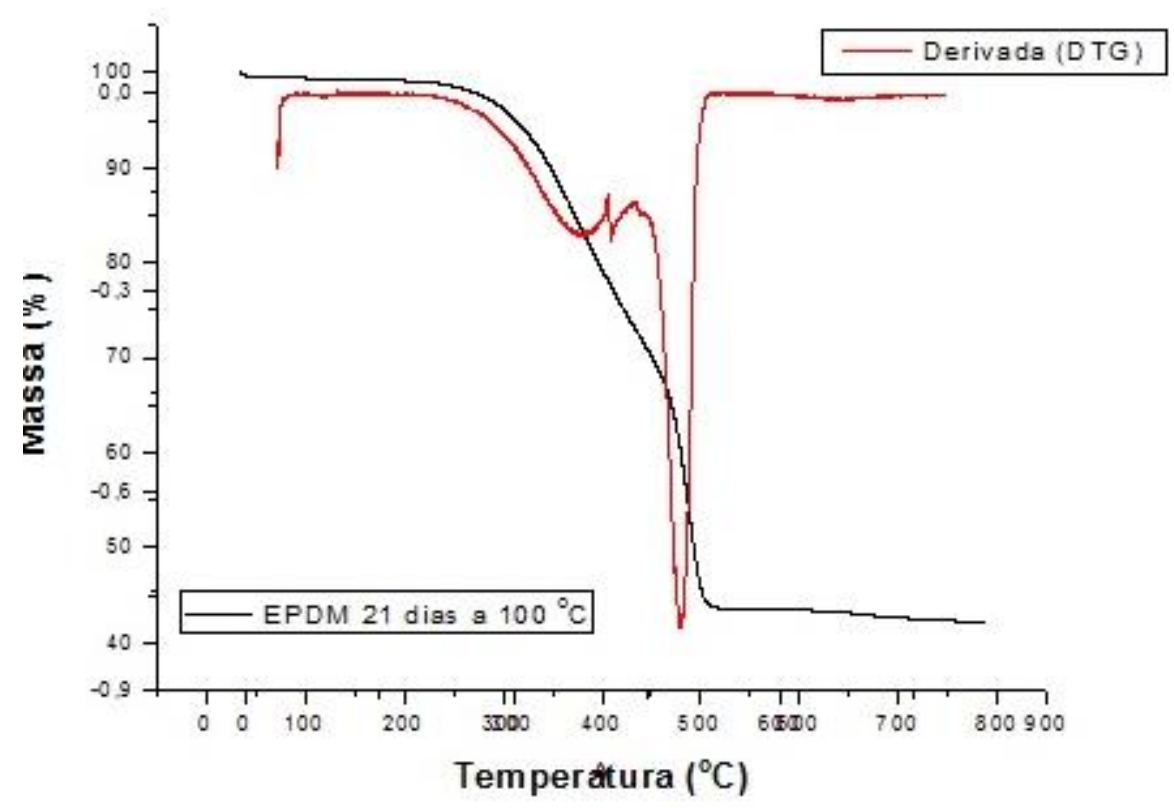

FIGURA 14: Degradação térmica das amostras de borracha EPDM envelhecidas: c) 21 dias a $100^{\circ} \mathrm{C}$.

O envelhecimento da borracha EPDM em $50{ }^{\circ} \mathrm{C}$ durante 21 dias (FIG.14b) mostra que esta temperatura não foi capaz de quebrar as ligações de enxofre e, neste caso, observa-se o evento de degradação dessas ligações após a degradação da borracha.

O envelhecimento da borracha EPDM na temperatura de $100{ }^{\circ} \mathrm{C}$ durante 21 dias (FIG. 14c), mostra novamente dois eventos de degradação como o do envelhecimento por 7 dias na mesma temperatura (FIG. 14a) e as mesmas considerações são válidas neste caso.

Como considerações sobre o estudo do tratamento térmico da borracha, pode-se concluir que a irradiação simultânea pode ser uma alternativa para a desvulcanização da borracha, se ocorrer em condições específicas, já que a degradação das ligações de enxofre acontece e isso se reflete na diminuição considerável da dureza do material em relação à borracha original. No entanto, resultados semelhantes podem ser obtidos a partir do envelhecimento da borracha se esta for submetida a uma temperatura de $100{ }^{\circ} \mathrm{C}$ durante o tempo mínimo de 7 dias. 
Neste trabalho optou-se por essa última condição por ser experimentalmente mais simples e economicamente mais viável, caso este processo seja aplicado industrialmente.

Sendo assim, desta parte do trabalho em diante, decidiu-se comparar o uso da borracha EPDM vulcanizada original e sem tratamento térmico, chamada a partir de agora de ST, com a borracha EPDM envelhecida durante 7 dias na temperatura de $100{ }^{\circ} \mathrm{C}$, daqui em diante chamada de TT, como componente minoritário para formar compósitos de PEAD reprocessado com EPDM, processado nessas condições.

\subsection{Reprocessamento do PEAD}

O reprocessamento do PEAD ocorreu como descrito nos itens 4.1.1 e 4.2.1 e o controle do reprocessamento foi realizado por espectrometria no infravermelho e termogravimetria como mostrado a seguir.

\subsubsection{Espectrometria no Infravermelho por Transformada de Fourier (FTIR)}

$O$ espectro de infravermelho do PEAD virgem (FIG. 15) mostra três bandas fortes características desse polímero de origem olefínica (SILVERSTEIN, 1979): região de $2.970 \mathrm{~cm}^{-1}$ a $2.850 \mathrm{~cm}^{-1}$ devido à vibração das deformações axial assimétrica e simétrica do grupo metileno $\left(-\mathrm{CH}_{2}-\right)$, região $1.477 \mathrm{~cm}^{-1}$ a $1.430 \mathrm{~cm}^{-1}$ devido à deformação angular simétrica no plano do $\left(-\mathrm{CH}_{2-}\right)$ e na região de $730 \mathrm{~cm}^{-}$ 1 a $710 \mathrm{~cm}^{-1}$, devido à vibração de deformação angular assimétrica no plano do ($\left.\mathrm{CH}_{2-}\right)$.

Vibrações fracas são observadas em $642 \mathrm{~cm}^{-1}$ devido à vibração angular fora do plano da ligação C-H olefínico; em $899 \mathrm{~cm}^{-1}$ devido à vibração do grupo vinila $\left(-\mathrm{H}_{2} \mathrm{C}=\mathrm{CH}_{2}-\right)$. Vibrações médias são observadas na região de 1.350 $\mathrm{cm}^{-1}$ a $1.150 \mathrm{~cm}^{-1}$ devido à deformação angular assimétrica em fase no plano do grupo (- $\mathrm{CH}_{2-}$ ), mais especificamente um dublete em $1.375 \mathrm{~cm}^{-1}$ e em $1.351 \mathrm{~cm}^{-1}$ devido à vibração de deformação em movimento de leque desse grupo, as bandas na região $1.639 \mathrm{~cm}^{-1}$ e $1.579 \mathrm{~cm}^{-1}$ estão relacionadas com a vibração da ligação com terminação $\mathrm{R}-\mathrm{CH}=\mathrm{CHR}$ e derivados desse grupamento, e finalmente 
em $1.735 \mathrm{~cm}^{-1}$, observa-se uma vibração de deformação axial da ligação dupla C=C- (SILVERSTEIN, 1979).

As amostras de PEAD virgem e após seus distintos reprocessamentos (FIG.15) mostraram além das bandas fortes características dos polímeros parafínicos, o desaparecimento da banda na região de $642 \mathrm{~cm}^{-1}$ e das bandas em $1.639 \mathrm{~cm}^{-1}$ e $1.579 \mathrm{~cm}^{-1}$, o que sugere a formação de ligações cruzadas nas condições do reprocessamento e também o surgimento de uma banda fraca na região de $940 \mathrm{~cm}^{-1}$, que é atribuída a vibrações do grupo transvinilideno ou éter vinílico; sua formação é atribuída a reações de grupos alquila provenientes de processo de degradação. Além disso, observa-se uma banda em $1.715 \mathrm{~cm}^{-1}$, que é caracteristíca do grupo carbonila $(>\mathrm{C}=\mathrm{O})$, indicando oxidação do material.

PEAD - virgem e reprocessados

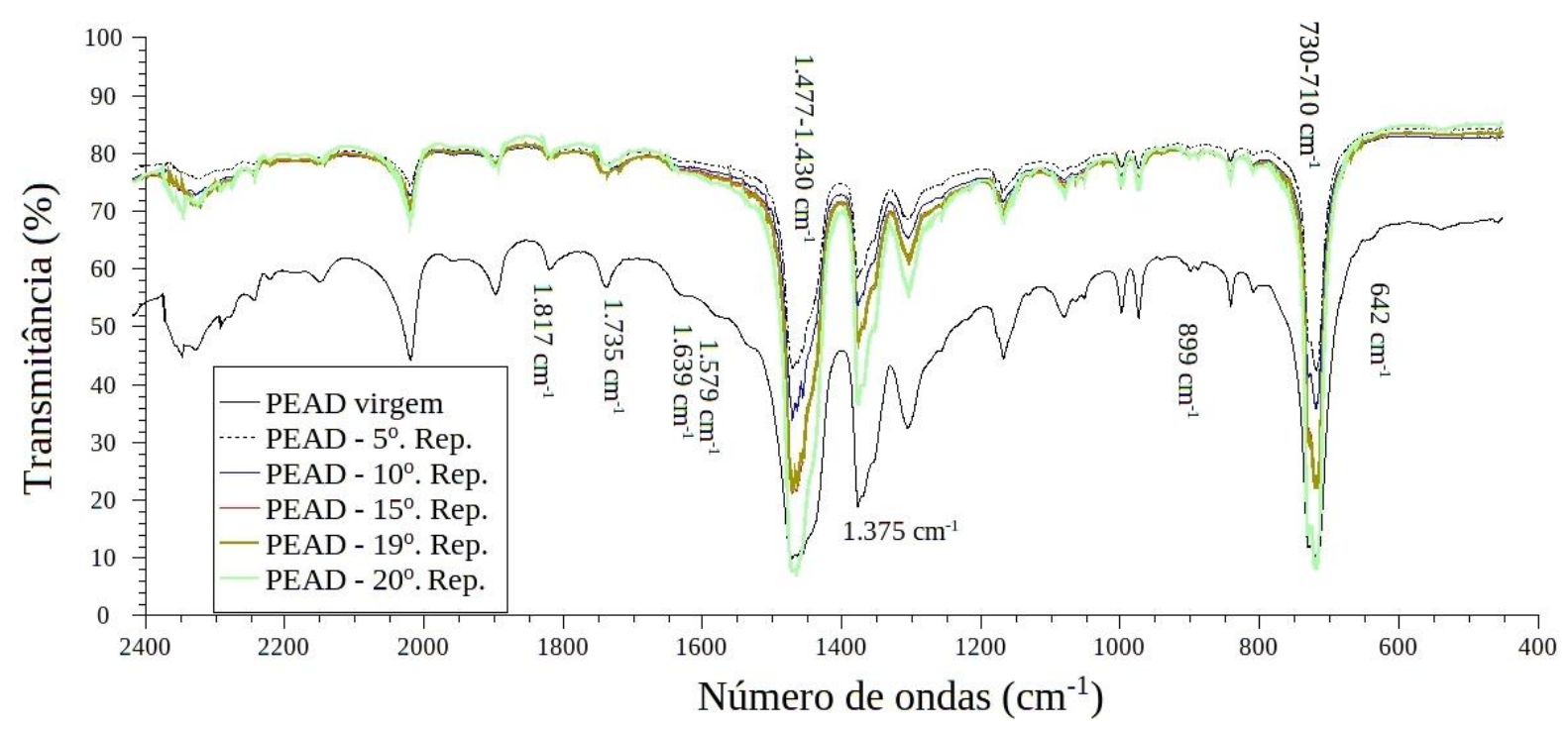

FIGURA 15: Espectros de infravermelho das amostras de PEAD virgem e reprocessados $(5,10,15,19$ e 20 ciclos de reprocesso).

Sendo assim, O PEAD reprocessado apresenta-se parte degradado, como também reticulado. Esses processos de degradação e reticulação simultaneamente acontecem desde os primeiros ciclos de reprocessamento; essa característica se deve ao processo de extrusão, onde o cisalhamento em alta temperatura permite a ocorrência de tais processos concorrentes. 
Quando o PEAD virgem e o PEAD reciclado são submetidos ao processo de irradiação (FIG. 16), observa-se comportamento semelhante nesses dois tipos de amostras: o desaparecimento das bandas em $642 \mathrm{~cm}^{-1}, 1.639 \mathrm{~cm}^{-1} \mathrm{e}$ $1.579 \mathrm{~cm}^{-1}$ (PEAD virgem), sugerindo a ocorrência de reticulação e o surgimento de uma banda em $1.715 \mathrm{~cm}^{-1}$ (PEAD virgem e PEAD reprocessado), característica do grupo carbonila $(>C=O)$ e que surge como produto de oxidação, evidencia a degradação destas amostras poliméricas.

PEAD - virgem e reprocessados irradiados

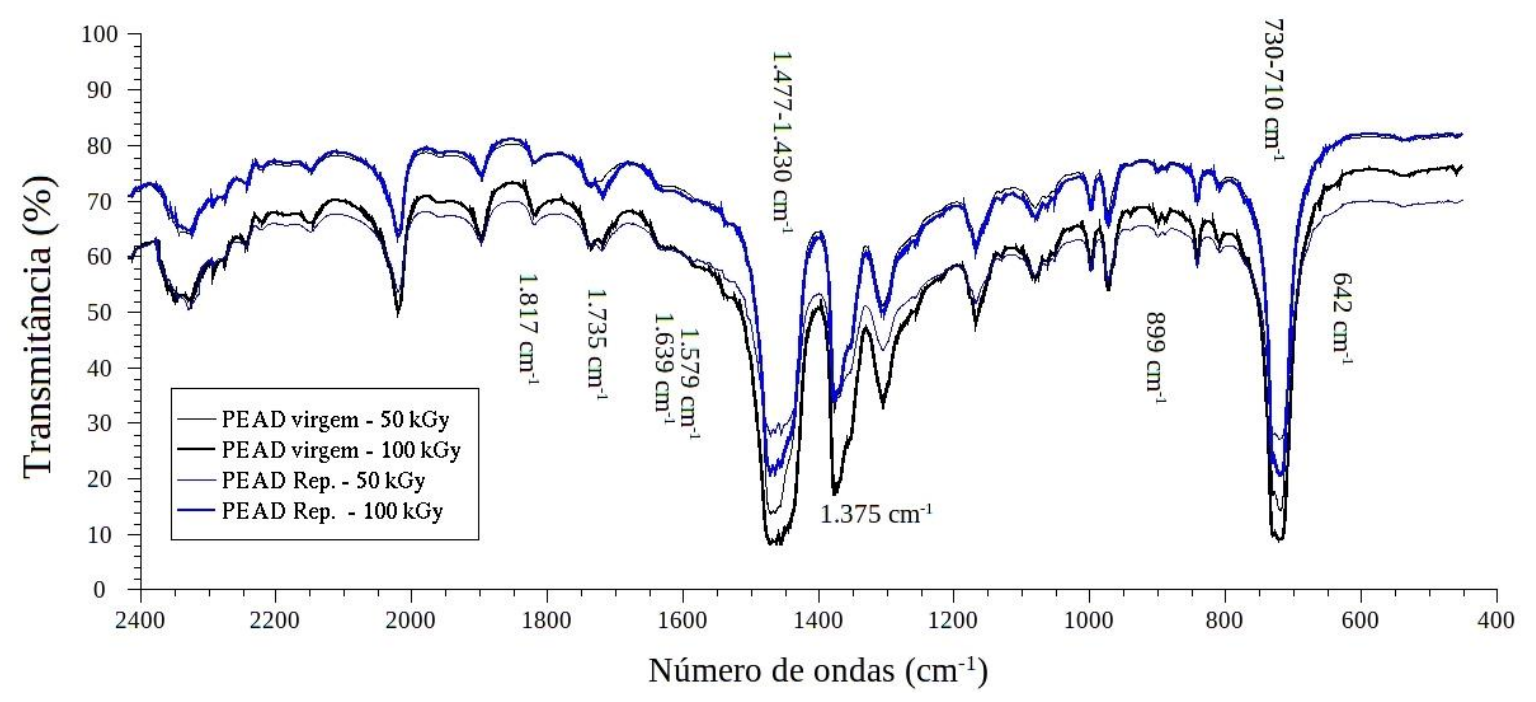

FIGURA 16: Espectros de infravermelho das amostras irradiadas por feixe de elétrons nas doses de 50 kGy e 100 kGy dos PEAD virgem e reprocessado (20 vezes).

\subsubsection{Termogravimetria (TG)}

A degradação térmica das amostras de PEAD virgem e de PEAD reprocessado foi avaliada por termogravimetria e calorimetria exploratória diferencial (DSC). Os resultados estão mostrados na TAB. 4 (a análise das amostras reprocessadas não foi realizada em replicata).

Segundo esses resultados, a temperatura do primeiro evento (endotérmico) ocorre entre os valores médios de $147^{\circ} \mathrm{C}$ a $151^{\circ} \mathrm{C}$ e acontece com até 3-5\% de perda de massa; esse evento corresponde à degradação de substâncias mais leves e pode ser identificado pelos picos apresentados na curva da derivada primeira da termogravimetria. Em seguida, o evento principal ocorre 
na faixa de temperatura de $260^{\circ} \mathrm{C}$ até $453^{\circ} \mathrm{C}$ com perda de massa média de $88 \%$, devido à termodegradação da matriz polimérica formada pelo esqueleto hidrocarbonado (CONTAT-RODRIGO, 2002).

Esses eventos estão descritos na literatura, porém se observa ainda mais dois: um na faixa de $450^{\circ} \mathrm{C}$ a $480^{\circ} \mathrm{C}$, cuja perda média de massa é de $8 \%$, que não é característico a menos que haja alguma contaminação, e outro na faixa de temperatura média de $470{ }^{\circ} \mathrm{C}$ a $560{ }^{\circ} \mathrm{C}$, relativos aos últimos $5 \%$ restantes do material (TAB. 4), que possivelmente está relacionado à degradação dos produtos provenientes da oxidação do material durante o ensaio, que foi realizado sob fluxo de ar (SCHEIRS, 1992).

O PEAD após o $5^{\circ}$ reprocessamento apresenta os mesmos eventos do PEAD virgem, porém o evento principal apresenta alteração na degradação, onde o pico principal está alargado com tendência à ocorrência de um outro evento menor, mas que está integrado ao evento principal. Além disso, o evento principal ocorre em menos de $50 \%$ da amostra.

Segundo a literatura consultada (CAMACHO e KARLSSON, 2002) esse comportamento de degradação térmica é apresentado pelo polietileno de alta densidade após o reprocessamento, indicando a possível quebra de ligações cruzadas e uma possível reticulação fomentada pelo reprocessamento e/ou por efeitos de degradação da matriz polimérica do material nessas condições.

O evento secundário em $481^{\circ} \mathrm{C}$ ocorre também com cerca de $50 \%$ de perda de massa, sugerindo a ocorrência de outro tipo de molécula, o que pode estar relacionado à ocorrência das moléculas oxidadas evidenciadas pelo FTIR.

A partir do $10^{\circ}$ reprocessamento observam-se dois valores máximos no pico principal da curva da derivada primeira da curva TG (DTA), e o comportamento dos materiais é semelhante ao observado no PEAD submetido ao $5^{\circ}$ reprocessamento.

Esses resultados convergem para aqueles observados no FTIR, onde não se observa diferenças abruptas entre os reprocessamentos. A degradação do material original é evidente, mas com as análises realizadas não é possível avaliar o grau de degradação em cada ciclo de reprocessamento. 
O processo de irradiação no PEAD virgem em 50 kGy mostra que além do evento endotérmico em $139{ }^{\circ} \mathrm{C}$ (na curva DTA), observa-se dois eventos: o principal em $433^{\circ} \mathrm{C}$ e o secundário em $525^{\circ} \mathrm{C}$. O evento principal ocorre em temperatura acima de $10{ }^{\circ} \mathrm{C}$ em relação à temperatura desse mesmo evento no material não irradiado e com perda de massa $5 \%$ maior do que aquela observada no PEAD virgem original, sugerindo a ocorrência de alguma alteração e que nesse caso provavelmente seja a reticulação do material. $O$ último evento tem semelhanças com relação à temperatura do pico e percentagem de perda de massa do PEAD original. $O$ aumento da dose absorvida para $100 \mathrm{kGy}$ promove o aumento da temperatura em que ocorre o evento principal, cerca de $19{ }^{\circ} \mathrm{C}$ acima da temperatura desse mesmo evento no material não irradiado, porém antes desse evento ocorre um estágio de degradação em cerca de $370{ }^{\circ} \mathrm{C}$ com cerca de $15 \%$ de perda de massa e o último evento em cerca de $530{ }^{\circ} \mathrm{C}$ com cerca de $5 \%$ de degradação. $O$ evento que ocorre antes do principal corresponde à quebra de ligações cruzadas do processo de reticulação que ocorre nessas condições de irradiação, tanto que o evento principal ocorre com uma percentagem menor $(8 \%)$ de perda de massa em relação ao material original. O último evento ocorre com variação de massa semelhante à do material original.

O PEAD reprocessado e irradiado nas doses de 50 kGy e 100 kGy apresenta comportamento qualitativo e quantitativo semelhante ao observado no PEAD virgem irradiado, indicando que mesmo reprocessado 20 vezes, a irradiação permite a ocorrência do processo de reticulação. 
TABELA 4: Parâmetros obtidos das curvas de termogravimetria das amostras de PEAD.

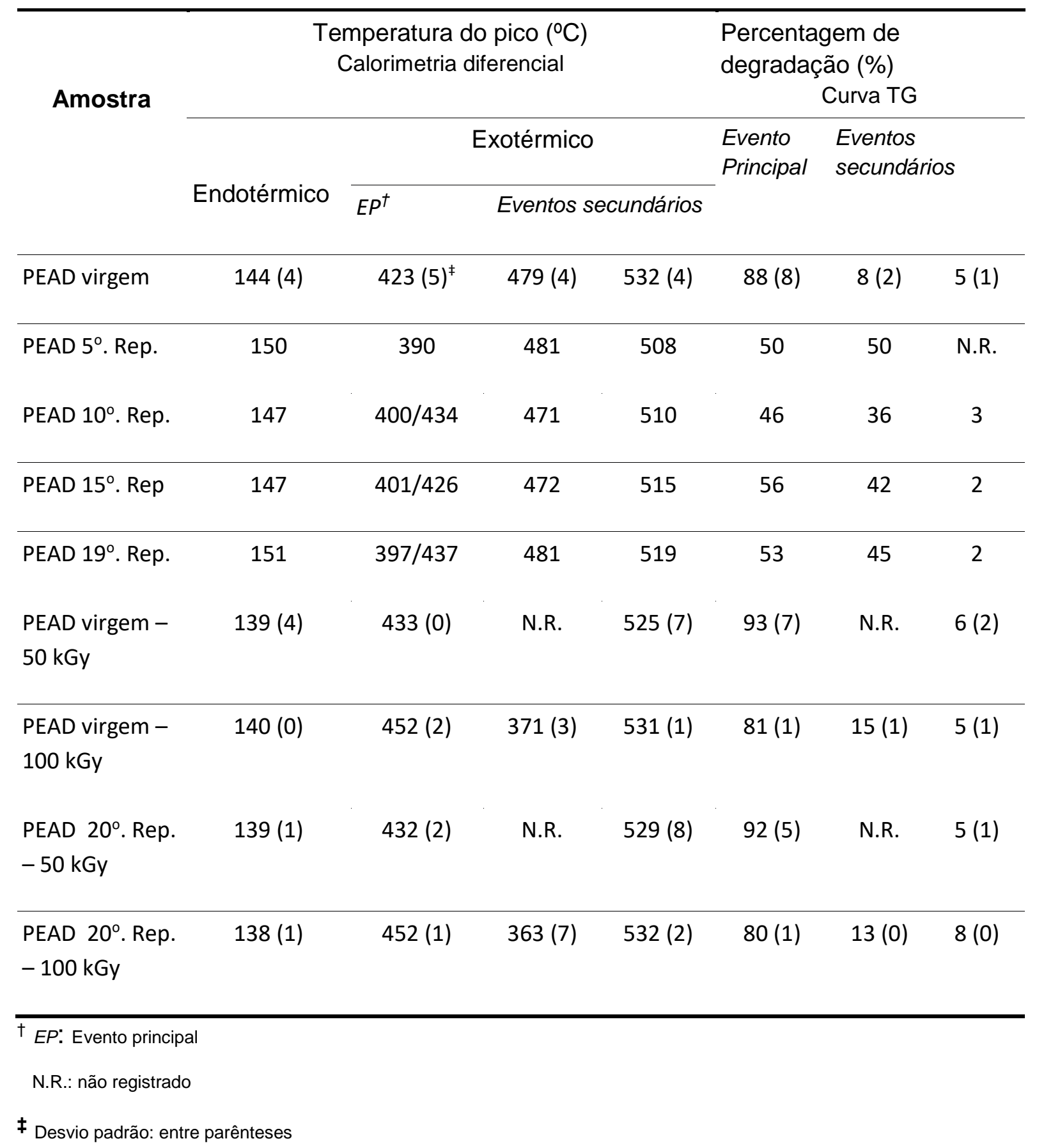

\subsection{Compósitos PEAD/EPDM reprocessados}

Os compósitos PEAD/EPDM reprocessados foram obtidos a partir da extrusão dos componentes com e sem a adição de agentes compatibilizantes, onde o melhor compatibilizante foi o metacrilato de glicidila na concentração de $1 \% \mathrm{p} / \mathrm{p}$. A avaliação preliminar do efeito da compatibilização foi realizada por 
termogravimetria e os demais ensaios foram realizados no sentido de caracterizar os materiais formados.

\subsubsection{Termogravimetria (TG)}

Os parâmetros das curvas termogravimétricas e também de calorimetria exploratória diferencial (DSC) dos compósitos PEAD/EPDM reprocessados não irradiados estão mostrados na TAB. 5.

O compósito PEAD virgem/1 \% EPDM ST sem compatibilizante apresentou o evento endotérmico na mesma faixa de temperatura que o PEAD virgem (porém em uma temperatura $5{ }^{\circ} \mathrm{C}$ maior). Nesse material, que foi obtido por extrusão e na ausência de compatibilizante, observa-se que o evento principal ocorre com a sobreposição de três reações distintas, o que é evidenciado por 3 máximos na calorimetria diferencial da degradação térmica, sendo que esse evento principal ocorre com cerca de $98 \%$ de perda de massa. Há ainda mais dois eventos de degradação: um na temperatura média de $533^{\circ} \mathrm{C}$ com $3 \%$ de perda de massa e que se refere provavelmente à degradação dos produtos de oxidação formados durante a degradação do PEAD (ver item 5.2), além da degradação das ligações de enxofre (ver item 5.1) e o outro em $640{ }^{\circ} \mathrm{C}$ com perda de massa fora do erro estatístico.

Quando esse mesmo tipo de compósito é obtido com a compatibilização do metacrilato de glicidila, o evento endotérmico ocorre em uma temperatura um pouco menor (valor próximo ao do PEAD virgem), o evento principal ocorre com cerca de $95 \%$ de perda de massa do material e observa-se 2 máximos, havendo ainda dois eventos secundários em cerca de $500{ }^{\circ} \mathrm{C}$ com cerca de $4 \%$ de perda de massa e outro na temperatura média de $542{ }^{\circ} \mathrm{C}$ com cerca de $1 \%$ de perda de massa. Nesse caso não foi observado um evento na faixa de temperatura de degradação do negro de fumo e produtos de oxidação da borracha, sugerindo que houve a compatibilização dos componentes no compósito.

Quando o compósito possui a mesma concentração de borracha (1\%), porém após o EPDM ter passado pelo tratamento térmico (TT), o evento endotérmico ocorre em uma temperatura um pouco mais baixa $\left(142{ }^{\circ} \mathrm{C}\right)$ e o 
evento principal, que ocorre com cerca de $95 \%$ de perda de massa, apresenta um único máximo em cerca de $435^{\circ} \mathrm{C}$, que é uma temperatura cerca de $35^{\circ} \mathrm{C}$ menor que o do evento de degradação do EPDM e cerca de $43^{\circ} \mathrm{C}$ menor que o do evento de degradação do PEAD virgem. Nesse compósito observa-se somente um evento secundário com cerca de $5 \%$ de perda de massa na temperatura média de $530{ }^{\circ} \mathrm{C}$. Esses resultados sugerem que o compósito se apresenta melhor disperso e com compatibilidade entre os componentes quando se utiliza a borracha previamente tratada termicamente.

O aumento da concentração de EPDM para $5 \%$ mostra que o evento endotérmico tende a ocorrer na temperatura de $140{ }^{\circ} \mathrm{C}$, cerca de $4^{\circ} \mathrm{C}$ abaixo da observada no mesmo evento para o PEAD virgem e o evento principal também ocorre em uma única temperatura (cerca de $430{ }^{\circ} \mathrm{C}$ ) com cerca de $90 \%$ a $94 \%$ de perda de massa, dependendo se houve tratamento térmico da borracha e reprocessamento do PEAD; os eventos secundários ocorrem na faixa de 532 $537{ }^{\circ} \mathrm{C}$ com cerca de $5 \%$ de perda de massa e na faixa de $634-639{ }^{\circ} \mathrm{C}$ com $1-3 \%$ de perda de massa, sugerindo que nessa composição o compósito apresenta os eventos relativos à degradação dos produtos de oxidação formados durante a degradação do PEAD, além da degradação das ligações de enxofre e à degradação do negro de fumo e produtos de oxidação da borracha. Somente no compósito PEAD virgem $/ 5$ \% EPDM TT é que se observa ainda um evento secundário na temperatura média de $471^{\circ} \mathrm{C}$ com cerca de $4 \%$ de degradação. Sendo assim, os resultados de degradação térmica das amostras dos compósitos com cerca de $5 \%$ de EPDM sugerem que ainda há compatibilização dos componentes quando se utiliza $1 \%$ do compatibilizante metacrilato de glicidila; 0 alto teor da borracha EPDM é revelado por esta metodologia em termos da evidência da presença das cargas contidas na borracha, no entanto, o evento adicional no compósito PEAD virgem/5 \% EPDM TT pode estar relacionado à degradação da borracha (ver item 5.1) e sugere que neste tipo de composição a compatibilização não é completa. 
TABELA 5: Parâmetros obtidos das curvas de termogravimetria dos compósitos PEAD/EPDM reprocessados não irradiados.

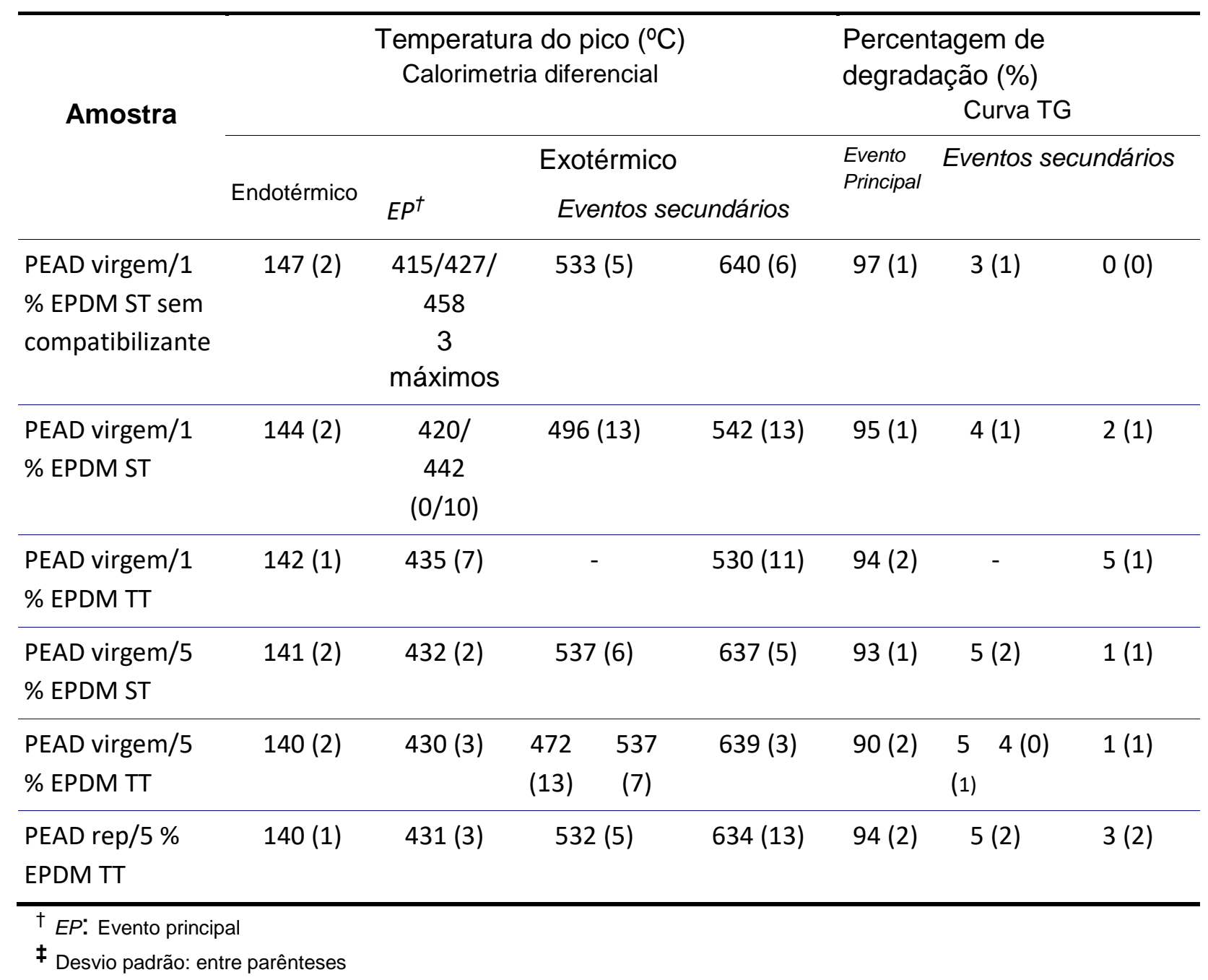

Os compósitos irradiados sob feixe de elétrons na dose de 50 kGy (TAB. 6), mostram resultados interessantes:

- Quando o teor da borracha EPDM é de $1 \%$, o evento endotérmico ocorre na faixa de $140-141^{\circ} \mathrm{C}$;

- O evento principal ocorre na faixa de $430-439{ }^{\circ} \mathrm{C}$ com perda de massa em torno de $90-93 \%$ e os eventos secundários na faixa de $475-480{ }^{\circ} \mathrm{C}$ com perda de massa entre $4-5 \%$ e na faixa de $537-540{ }^{\circ} \mathrm{C}$ com perda de massa entre 5-6\%;

- Somente no compósito que utilizou o EPDM TT surgiram dois máximos no evento principal. 
Comparando esses resultados com os dos compósitos de mesma composição e não irradiados, parece que houve alguma compatibilização dos componentes naqueles compósitos que possuem EPDM ST, mas o contrário ocorreu nos compósitos que são formados por EPDM TT.

Nesse caso, é importante lembrar que o EPDM TT sofreu a ação térmica duas vezes: uma antes de ser incorporada à mistura polimérica e outra durante a formação do compósito propriamente dito, sendo assim, a borracha tratada termicamente entra na composição degradada; ao sofrer o processo de irradiação a degradação do material torna-se preponderante. No caso do EPDM ST parece haver alguma compatibilização porque o material não está tão degradado quanto no caso do EPDM TT e é possível que uma parte do dieno da sua composição possa ter sido imprescindível na formação de ligações cruzadas.

O aumento da concentração de EPDM mostra influência na alteração dessas observações. O evento endotérmico está em torno de $140{ }^{\circ} \mathrm{C}$ como observado anteriormente, porém o evento principal apresenta dois máximos em faixas de temperaturas distintas: um em $426-428{ }^{\circ} \mathrm{C}$ e outro em $453-461{ }^{\circ} \mathrm{C}$, nos casos em que o termoplástico em maior composição é o PEAD virgem, e que ocorre com menor perda de massa (88-90 \%) em relação aos não irradiados. Além dos eventos secundários na faixa de $477^{\circ} \mathrm{C}$ (somente no compósito com EPDM ST) e $531^{\circ} \mathrm{C}$ que ocorrem ambos com perda de massa na faixa de $7 \%$, observa-se ainda o evento em $643-644{ }^{\circ} \mathrm{C}$ com perda de massa em torno de $1 \%$.

O efeito da degradação dos compósitos é evidente e é fomentada pela presença da borracha EPDM, sendo que os compósitos com EPDM TT parecem sofrer mais o efeito de degradação sob o processo de irradiação, sendo que neste caso não se observa a faixa de sua degradação $\left(470-480{ }^{\circ} \mathrm{C}\right)$, observado no compósito não irradiado.

Quando o compósito é formado pelo PEAD reprocessado e por $5 \%$ de EPDM TT, observa-se o mesmo comportamento de degradação verificado para o compósito PEAD virgem/5 \% EPDM ST. 
TABELA 6: Parâmetros obtidos das curvas de termogravimetria dos compósitos PEAD/EPDM reprocessados irradiados por feixe de elétrons na dose de 50 kGy.

\begin{tabular}{|c|c|c|c|c|c|c|c|c|c|}
\hline \multirow[t]{3}{*}{ Amostra } & \multicolumn{6}{|c|}{$\begin{array}{l}\text { Temperatura do pico }\left({ }^{\circ} \mathrm{C}\right) \\
\text { Calorimetria diferencial }\end{array}$} & \multicolumn{3}{|c|}{$\begin{array}{l}\text { Percentagem de } \\
\text { degradação (\%) } \\
\text { Termograma }\end{array}$} \\
\hline & \multirow{2}{*}{ Endotérmico } & \multicolumn{5}{|c|}{ Exotérmico } & \multirow{2}{*}{$\begin{array}{l}\text { Evento } \\
\text { Principal }\end{array}$} & \multicolumn{2}{|c|}{ Eventos secundários } \\
\hline & & $E P^{\dagger}$ & \multicolumn{4}{|c|}{ Eventos secundários } & & & \\
\hline PEAD virgem/1 & $140(1)$ & $430(6)$ & \multicolumn{2}{|c|}{476 (1) } & \multirow{2}{*}{\multicolumn{2}{|c|}{$540(3)$}} & $90(3)$ & $5(1)$ & $6(1)$ \\
\hline \multicolumn{8}{|l|}{ \% EPDM ST } & & \\
\hline PEAD virgem $/ 1$ & $141(2)$ & $421 /$ & \multicolumn{2}{|c|}{$480(0)$} & \multicolumn{2}{|c|}{$537(4)$} & $93(3)$ & $4(0)$ & $5(2)$ \\
\hline \% EPDM TT & & $439(0 / 9)$ & & & & & & & \\
\hline PEAD virgem $/ 5$ & $141(1)$ & $428 /$ & \multicolumn{2}{|c|}{477} & 531 & 644 & $88(5)$ & 7 & $8(3) \quad 1(1)$ \\
\hline$\%$ EPDM ST & & $453(4 / 0)$ & & & (6) & $(1)$ & & & \\
\hline PEAD virgem $/ 5$ & $140(1)$ & $426 /$ & \multicolumn{2}{|c|}{$515(34)$} & \multicolumn{2}{|c|}{$643(2)$} & $90(4)$ & $7(1)$ & $1(0)$ \\
\hline \multirow[t]{2}{*}{ \% EPDM TT } & & 461 & & & & & & & \\
\hline & & $(0 / 24)$ & & & & & & & \\
\hline PEAD rep/5 \% & $140(1)$ & $424(7)$ & 480 & 539 & 64 & (4) & $89(2)$ & $68(2)$ & $1(1)$ \\
\hline EPDM TT & & & (0) & (5) & & & & (0) & \\
\hline
\end{tabular}

$\dagger_{E P:}$ Evento principal

‡ Desvio padrão: entre parênteses

O aumento da dose para 100 kGy (TAB. 7) mostra que nos compósitos PEAD virgem $/ 1$ \% EPDM o processo de degradação ocorre de maneira semelhante e independe se o EPDM passou por tratamento térmico ou não. Apesar de o evento principal de degradação apresentar dois máximos de temperatura, este evento ocorre com perda de massa menor (82-83 \%) e observa-se um evento secundário anterior ao evento principal que ocorre em cerca de $361{ }^{\circ} \mathrm{C}$ com $10-11 \%$ de perda de massa, podendo estar relacionado à formação de ligações cruzadas, como visto na TAB. 4 para os termoplásticos virgem e reprocessados irradiados na mesma dose.

O evento em $350^{\circ} \mathrm{C}$ é observado também no compósito PEADvirgem $/ 5$ \% EPDM ST em adição às verificações na menor dose (TAB. 6), sugerindo que há a formação de ligações cruzadas concorrentemente ao processo de degradação do material, ocorrendo com $7 \%$ de perda de massa. O evento principal ocorre com menor perda de massa (cerca de $84 \%$ ) em relação ao 
verificado na dose menor e o evento secundário em $474^{\circ} \mathrm{C}$ ocorre com cerca de $10 \%$ de perda de massa, sugerindo que houve alterações a nível molecular no compósito deste tipo.

Os compósitos PEAD (virgem e reprocessado)/5 \% EPDM TT apresentaram comportamento de degradação térmica semelhante ao observado na dose menor, sugerindo que a degradação é preponderante para este tipo de compósito mas não há alterações significativas quando o compósito é irradiado na maior dose.

TABELA 7: Parâmetros obtidos das curvas de TG dos compósitos PEAD/EPDM reprocessados irradiados por feixe de elétrons na dose de $100 \mathrm{kGy}$.

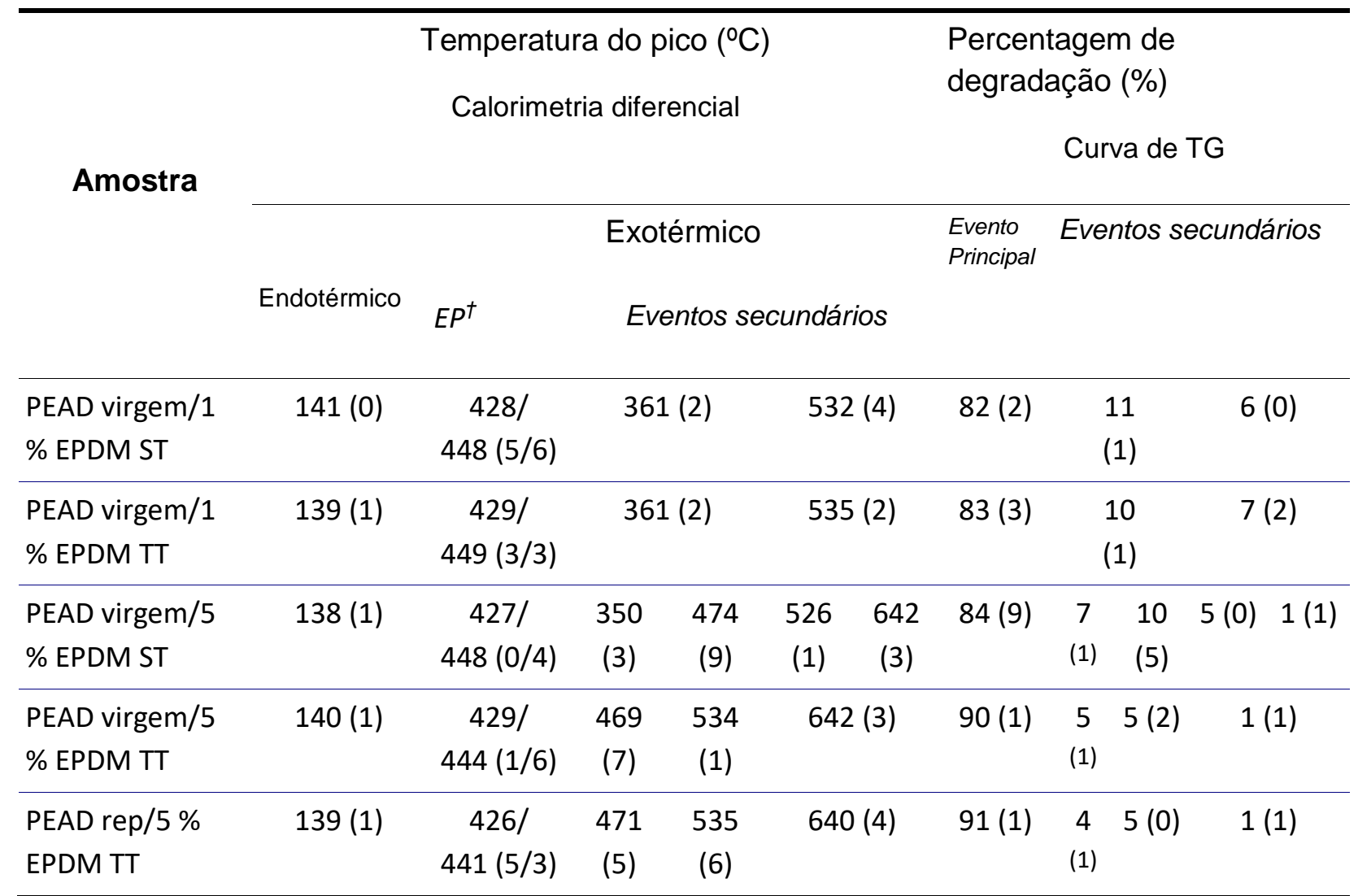

$\dagger$ EP: Evento principal

¥ Desvio padrão: entre parênteses

\subsubsection{Calorimetria Exploratória Diferencial (DSC)}

Os resultados da calorimetria exploratória diferencial das amostras não irradiadas do termoplástico virgem e reprocessado, bem como dos seus compósitos com o EPDM (ST e TT) estão apresentados na TAB. 8. 
O PEAD virgem apresenta temperatura média de fusão $\left(T_{f}\right)$ em $133^{\circ} \mathrm{C}$ e temperatura média de cristalização $\left(T_{c}\right)$ em $116^{\circ} \mathrm{C}$, e um grau de cristalinidade (X) médio de $49 \%$. Quando este termoplástico é reprocessado 20 vezes, a sua $T_{f}$ diminui $1^{\circ} \mathrm{C}$, sugerindo que há uma tendência à degradação. $A T_{c}$ apresenta-se com o mesmo valor, indicando que não houve alterações quanto à cristalização nestas duas amostras. O grau de cristalinidade da amostra reprocessada é maior do que o da amostra original, sugerindo uma tendência à reticulação que se deve aos sucessivos reprocessamentos do PEAD.

Os compósitos PEAD virgem com $1 \%$ de EPDM (ST ou TT) mostraram semelhança nos valores dos parâmetros: $T_{f}$ médio de $134{ }^{\circ} \mathrm{C}$ e $T_{c}$ médio de 114 ${ }^{\circ} \mathrm{C}$, sugerindo que a inserção de EPDM não promoveu alterações abruptas; a pequena diminuição da $T_{c}$ média, pode estar relacionada à diminuição da organização das cadeias poliméricas devido ao aumento de massa desse material não cristalino. O grau de cristalinidade apresenta-se um pouco maior nas amostras contendo EPDM sem tratamento térmico, sugerindo que nessas condições há uma tendência à reticulação.

Os compósitos PEAD virgem e reprocessado com $5 \%$ de EPDM (ST ou TT) mostraram o mesmo valor de $\mathrm{T}_{f}$ médio $\left(133^{\circ} \mathrm{C}\right)$ e $\mathrm{T}_{\mathrm{c}}$ médio $\left(114{ }^{\circ} \mathrm{C}\right)$ indicando não haver alterações nessas propriedades com o aumento da concentração da borracha. O grau de cristalinidade nessas amostras é muito semelhante, mas nesse caso, o compósito que contém a borracha com tratamento térmico parece ter maior tendência à reticulação. 
TABELA 8: Parâmetros obtidos das curvas DSC dos PEAD virgem e reprocessado, e compósitos PEAD/EPDM não irradiados.

\begin{tabular}{lcccc}
\hline Amostra & Tf $\left({ }^{\circ} \mathrm{C}\right)$ & $\Delta \mathrm{Hf}(\mathrm{J} / \mathrm{mol})$ & $\mathbf{X}_{\mathrm{c}}(\%)$ & $\mathrm{Tc}\left({ }^{\circ} \mathrm{C}\right)$ \\
\hline PEAD Virgem & $133(1)$ & $142(9)$ & $49(3)$ & $116(0)$ \\
\hline PEAD Rep. & $132(1)$ & $150(4)$ & $52(1)$ & $116(0)$ \\
\hline $\begin{array}{l}\text { PEAD 1\% EPDM } \\
\text { ST }\end{array}$ & $134(1)$ & $150(9)$ & $52(3)$ & $114(1)$ \\
\hline $\begin{array}{l}\text { PEAD 1\% EPDM } \\
\text { TT }\end{array}$ & $134(1)$ & $143(1)$ & $49(0)$ & $114(1)$ \\
\hline $\begin{array}{l}\text { PEAD 5\% EPDM } \\
\text { ST }\end{array}$ & $133(1)$ & $142(2)$ & $49(1)$ & $114(0)$ \\
\hline $\begin{array}{l}\text { PEAD 5\% EPDM } \\
\text { TT }\end{array}$ & $133(1)$ & $145(12)$ & $50(4)$ & $114(1)$ \\
\hline $\begin{array}{l}\text { PEADr 5\% } \\
\text { EPDM TT }\end{array}$ & $133(1)$ & $147(4)$ & $51(1)$ & $114(1)$ \\
\hline
\end{tabular}

Não irradiados (entre parênteses: desvio padrão).

Quando a irradiação na dose de 50 kGy é aplicada (TAB. 9), observase que o PEAD virgem apresenta aumento na reticulação em relação ao termoplástico não irradiado e isso é evidenciado pelo aumento no índice de cristalinidade e pela diminuição da $T_{c}$. O PEAD reprocessado também apresenta tendência ao aumento na reticulação (maior $X_{c}$ e diminuição no $T_{c}$ ) e que essa tendência supera ao do termoplástico original.

Os compósitos com $1 \%$ de EPDM após a absorção da dose de 50 kGy apresentaram aumento de $X_{c}$ e diminuição de $T_{c}$ em relação aos não irradiados, indicando aumento da reticulação do material, embora o processo de irradiação induza à degradação desses materiais (diminuição da $T_{f}$ ).

O grau de cristalinidade praticamente não é alterado quando o teor de EPDM é maior, embora a $T_{c}$ apresente tendência de queda. $O$ processo de 
irradiação nesse caso apresenta-se com tendência à degradação, o que é evidenciado pela diminuição de $T_{\text {f }}$. No compósito PEAD reprocessado/5 \% EPDM TT e irradiado a 50 kGy, observa-se a diminuição do grau de cristalinidade além da diminuição de $T_{c}$, sugerindo que a degradação ocorre neste tipo de amostra.

TABELA 9: Parâmetros obtidos das curv as DSC dos PEAD virgem e reprocessado e compósitos $\mathrm{PEAD/EPDM}$ irradiados sob feixe de elétrons em 50 kGy.

\begin{tabular}{lcccc}
\hline \multicolumn{1}{c}{ Amostra } & $\operatorname{Tf}\left({ }^{\circ} \mathrm{C}\right)$ & $\begin{array}{c}\Delta \mathrm{Hf} \\
(\mathrm{J} / \mathrm{mol})\end{array}$ & $\mathbf{X}_{\mathrm{c}}(\%)$ & $\mathrm{Tc}\left({ }^{\circ} \mathrm{C}\right)$ \\
\hline PEAD Virgem & $133(1)$ & $147(19)$ & $51(6)$ & $112(1)$ \\
\hline PEAD Rep. & $132(1)$ & $161(5)$ & $56(2)$ & $114(1)$ \\
\hline $\begin{array}{l}\text { PEAD 1\% } \\
\text { EPDM ST }\end{array}$ & $132(1)$ & $158(5)$ & $55(2)$ & $112(1)$ \\
\hline $\begin{array}{l}\text { PEAD 1\% } \\
\text { EPDM TT }\end{array}$ & $133(1)$ & $160(23)$ & $55(8)$ & $112(1)$ \\
\hline $\begin{array}{l}\text { PEAD 5\% } \\
\text { EPDM ST }\end{array}$ & $132(1)$ & $141(2)$ & $49(1)$ & $113(0)$ \\
\hline $\begin{array}{l}\text { PEAD 5\% } \\
\text { EPDM TT }\end{array}$ & $132(1)$ & $144(6)$ & $50(2)$ & $113(1)$ \\
\hline $\begin{array}{l}\text { PEADr 5\% } \\
\text { EPDM TT }\end{array}$ & $133(1)$ & $132(15)$ & $46(5)$ & $113(1)$ \\
\hline
\end{tabular}

Finalmente, sob a dose absorvida de 100 kGy (TAB. 10), O PEAD virgem praticamente não apresentou alterações nos valores de $X_{c}$ e $\quad T_{c}$; apresentou pequena diminuição em relação à amostra irradiada em dose menor, sugerindo que nos níveis de dose estudados o processo de reticulação deste tipo de amostra não sofre alterações. A diminuição da $T_{f}$ sugere que há a tendência de degradação na amostra exposta a essa dose.

No PEAD reprocessado, a diminuição do valor de $X_{c}$ sugere que a degradação é maior do que no PEAD virgem nessa dose. 
Nos compósitos verifica-se que $\mathrm{X}_{\mathrm{c}}$ diminui, sugerindo que o processo de degradação ocorre em todos esses compósitos. O compósito PEAD reprocessado/5 \% EPDM TT, apresentou maior valor da $T_{c}$ média em 100 kGy, indicando que nessas condições a ordenação das cadeias é maior.

TABELA 10: Parâmetros obtidos das curvas DSC dos PEAD virgem e reprocessado e compósitos PEAD/EPDM irradiados sob feixe de elétrons em 100 kGy.

\begin{tabular}{lcccc}
\hline \multicolumn{1}{c}{ Amostra } & $\mathrm{Tf}(\circ \mathrm{C})$ & $\Delta \mathrm{Hf}(\mathrm{J} / \mathrm{mol})$ & $\mathrm{X}_{\mathrm{c}}(\%)$ & $\mathrm{Tc}\left({ }^{\circ} \mathrm{C}\right)$ \\
\hline PEAD Virgem & $132(1)$ & $145(11)$ & $50(4)$ & $111(1)$ \\
\hline PEAD Rep. & $132(1)$ & $131(5)$ & $45(2)$ & $112(1)$ \\
\hline $\begin{array}{l}\text { PEAD 1\% EPDM } \\
\text { ST }\end{array}$ & $132(0)$ & $149(18)$ & $51(6)$ & $112(0)$ \\
\hline $\begin{array}{l}\text { PEAD 1\% EPDM } \\
\text { TT }\end{array}$ & $131(1)$ & $137(18)$ & $47(6)$ & $113(1)$ \\
\hline $\begin{array}{l}\text { PEAD 5\% EPDM } \\
\text { ST }\end{array}$ & $131(1)$ & $136(6)$ & $47(2)$ & $112(1)$ \\
\hline $\begin{array}{l}\text { PEAD 5\% EPDM } \\
\text { TT }\end{array}$ & $132(1)$ & $130(25)$ & $45(8)$ & $113(2)$ \\
\hline $\begin{array}{l}\text { PEADr 5\% } \\
\text { EPDM TT }\end{array}$ & $132(1)$ & $141(19)$ & $49(6)$ & $114(1)$ \\
\hline
\end{tabular}

As figuras 17 a 19 mostram em gráfico os resultados das tabelas 8 a 10, porém estão organizadas segundo os parâmetros medidos $T_{f}, T_{c}$ e $X_{c}$ para melhor visualização do comportamento segundo cada tipo de amostra.

Segundo essas figuras, pode-se observar que dentre os compósitos não irradiados, o PEAD virgem/1 \% EPDM ST e TT apresentaram os maiores valores da $T_{f}$ média (FIG. 17), sugerindo que a degradação é baixa quando comparada ao dos outros compósitos e dos termoplásticos virgem e 
reprocessado, fato este que pode estar relacionado a esse nível de concentração da borracha.

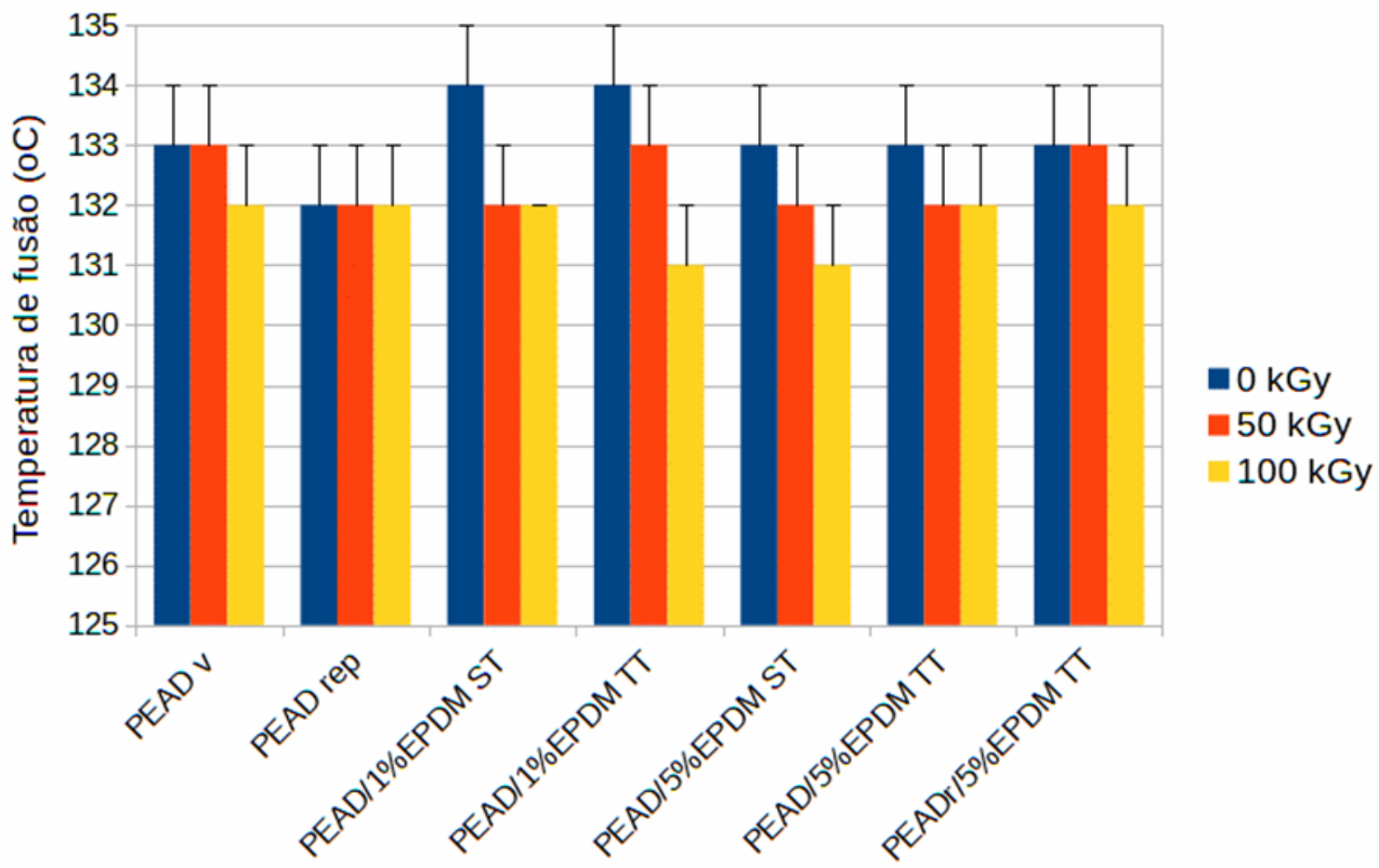

FIGURA 17: Temperatura de fusão média extraída das curvas de DSC das amostras irradiadas e não irradiadas de PEAD virgem e reprocessado e dos compósitos PEAD/EPDM.

Nos compósitos a reticulação tem maior índice na dose de 50 kGy (FIG. 18), cujo valor é parecido àquele obtido para o termoplástico reprocessado.

A inserção de EPDM nos compósitos diminui a $T_{c}$ (FIG. 19) e consequentemente, diminui a organização das cadeias hidrocarbonadas na mistura final, quando se compara ao mesmo comportamento observado para os termoplásticos virgem e reprocessado; em geral, o processo de irradiação prejudica esse comportamento. 


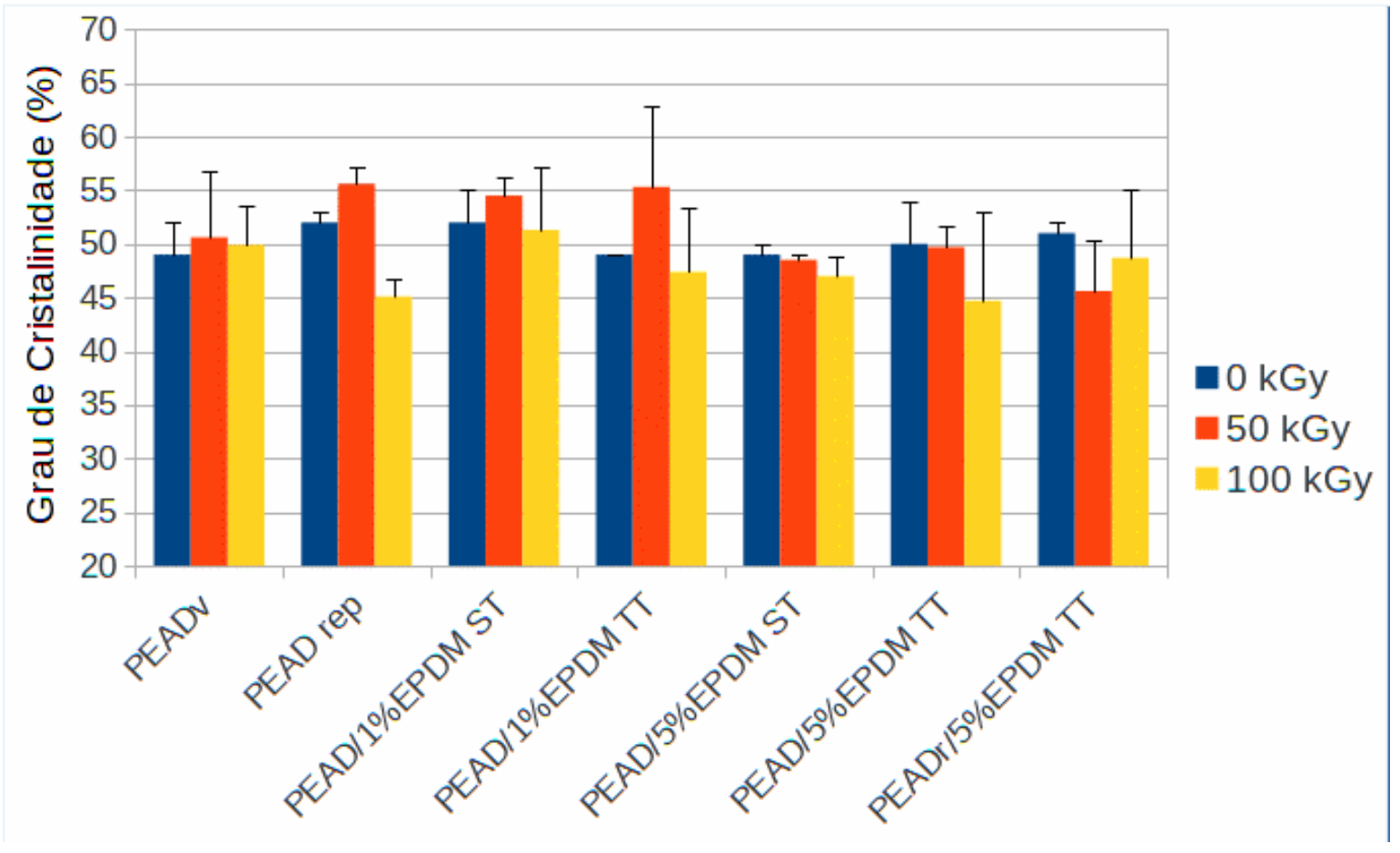

FIGURA 18: Grau de cristalinidade para PEAD virgem e reprocessado, e compósitos PEAD (virgem e reprocessado)/EPDM.

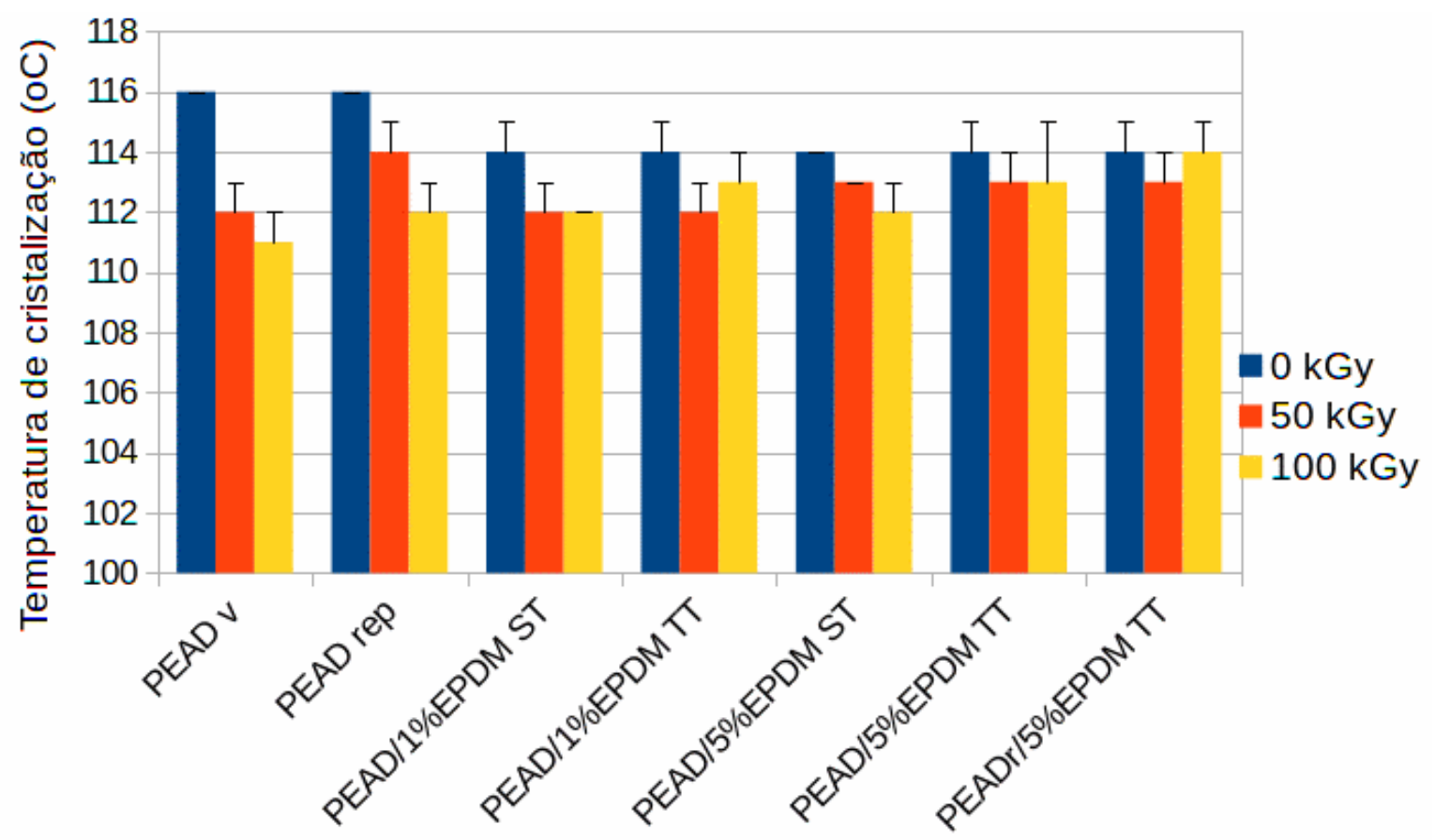

FIGURA 19: Temperatura de cristalização média extraída das curvas de DSC das amostras irradiadas e não irradiadas de PEAD virgem e reprocessado e dos compósitos PEAD/EPDM. 
5.3.3 Espectrometria no Infravermelho por Transformada de Fourier (FTIR)

Os compósitos PEAD virgem/1 \% EPDM ST e TT (FIG. 20a e 20b) não irradiados apresentam algumas diferenças em relação ao PEAD virgem:

a) A banda original em $1.735 \mathrm{~cm}^{-1}$, devido à vibração de deformação axial da ligação dupla $-\mathrm{C}=\mathrm{C}$-, desloca-se para $1.725 \mathrm{~cm}^{-1}$ sugerindo que no compósito nessas condições ocorre alterações em relação ao modo de vibração desse grupo funcional. Além disso, a banda torna-se mais profunda, indicando o fator quantitativo nessa alteração;

b) A banda em $1.375 \mathrm{~cm}^{-1}$ devido à vibração de deformação em movimento de leque do grupo metileno, torna-se mais larga e menos profunda, indicando alterações qualitativas e quantitativas no modo de vibração nessa região; essa alteração pode também estar relacionada à presença do grupo metila vindo do propileno que constitui a borracha;

c) A banda em $940 \mathrm{~cm}^{-1}$ atribuída a vibrações do grupo transvinilideno ou éter vinílico torna-se mais profunda em ambos os tipos de amostra, indicando a alteração quantitativa nessas condições.

a)

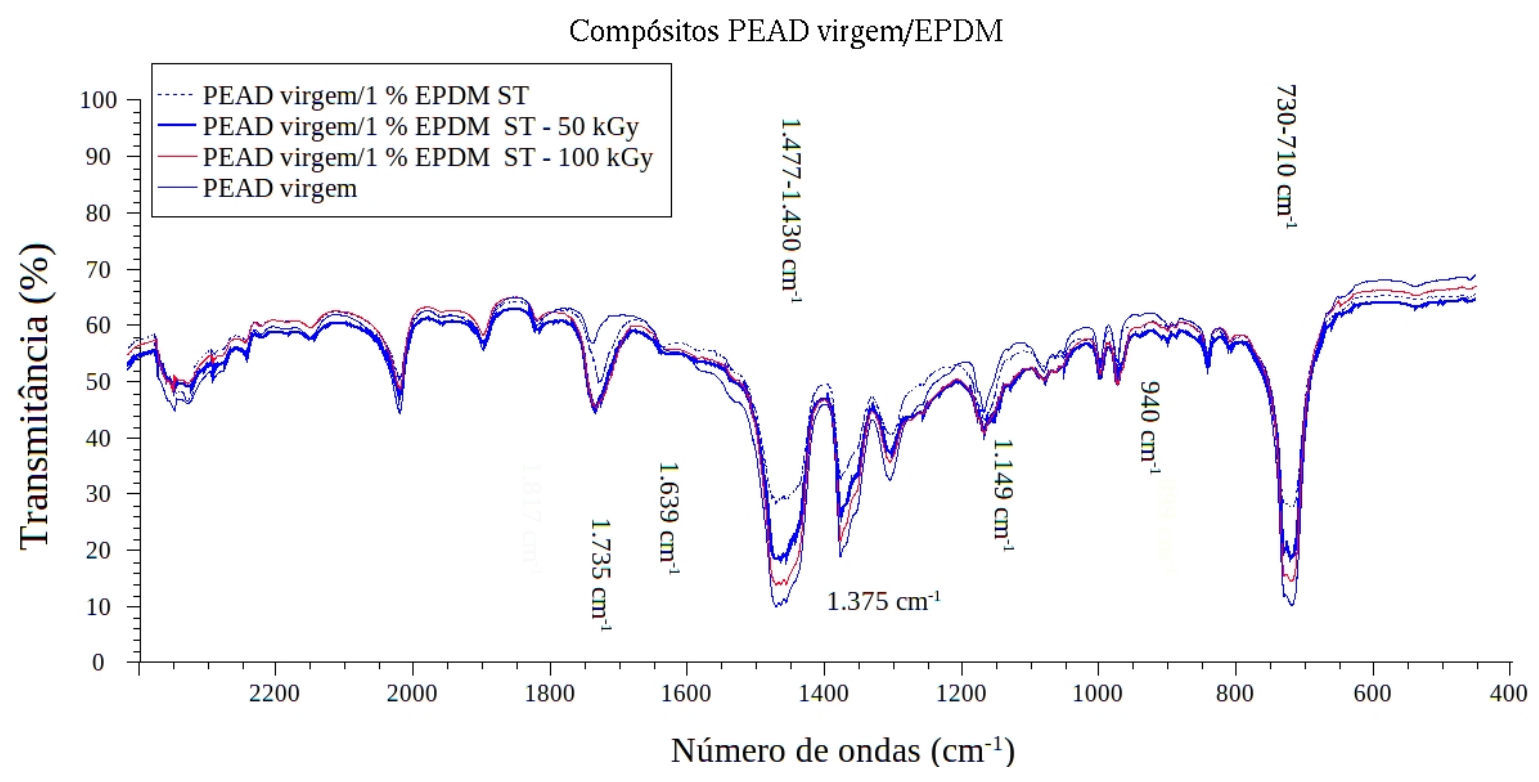

FIGURA 20: Espectros de infravermelho das amostras não irradiadas e irradiadas por feixe de elétrons nas doses de 50 kGy e 100 kGy dos compósitos PEAD virgem $/ 1 \%$ EPDM a) sem tratamento (ST) (continua). 
b)

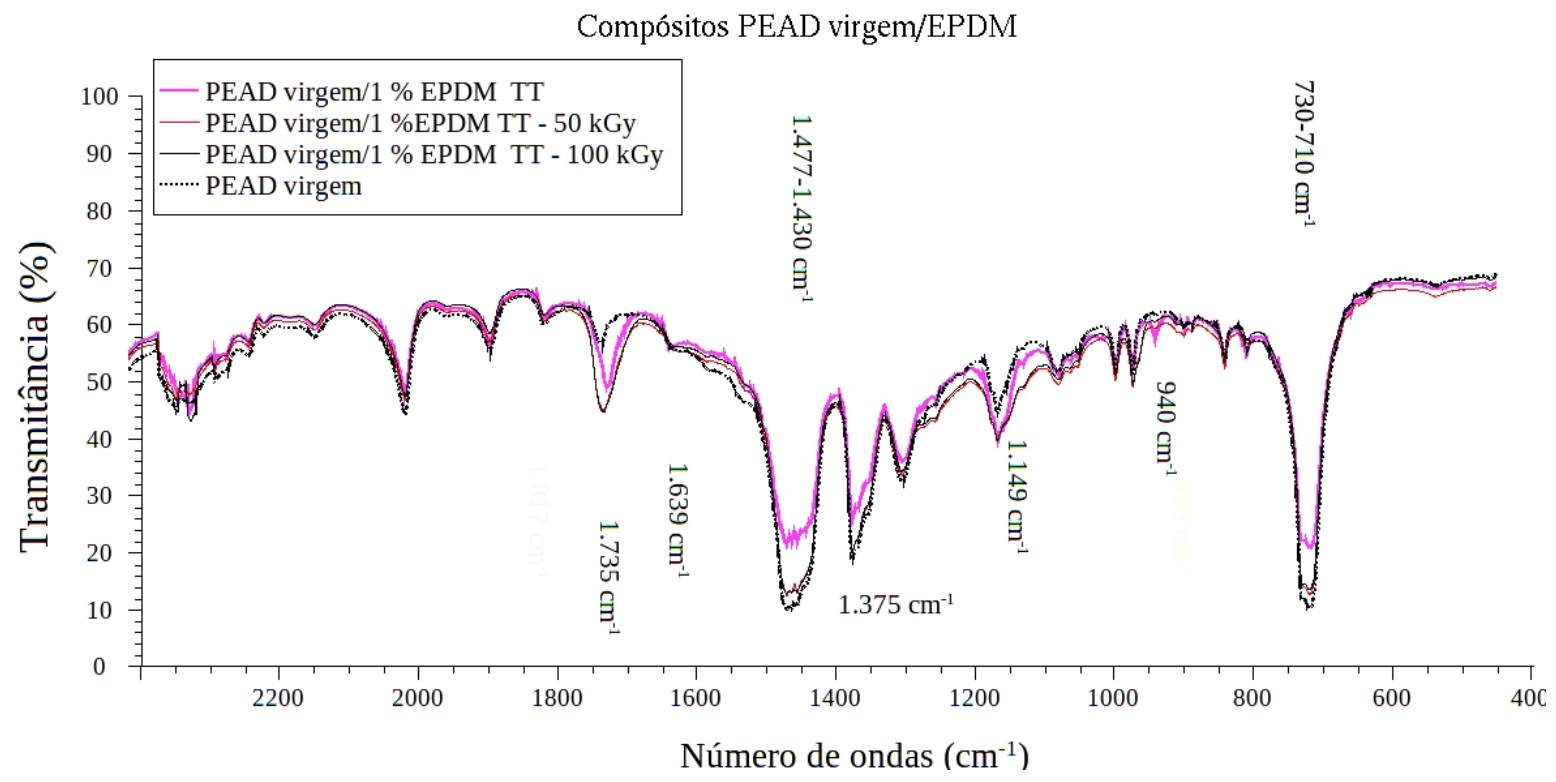

FIGURA 20: Espectros de infravermelho das amostras não irradiadas e irradiada por feixe de elétrons nas doses de 50 kGy e 100 kGy dos compósitos PEAD virgem $/ 1 \%$ EPDM b) com tratamento térmico (TT).

Essas observações sugerem que não há diferença entre 0 comportamento vibracional do compósito contendo EPDM ST ou TT. Também, a inserção do EPDM em ambos os modos aumenta a concentração de insaturações no produto final, sugerindo que, após sofrer reprocessamento, o EPDM ainda guarda algum teor de dieno na sua composição.

Após o processo de irradiação, ainda na FIG. 20, o espectro desses compósitos apresenta diminuição da banda em $940 \mathrm{~cm}^{-1}$ ou até mesmo o seu desaparecimento; a banda em $1.375 \mathrm{~cm}^{-1}$ volta a ser profunda e mais estreita que os compósitos não irradiados, e a banda em $1.735 \mathrm{~cm}^{-1}$ não apresenta deslocamento em termos de frequência e a sua profundidade é semelhante ao apresentado no espectro dos compósitos não irradiados. Esses resultados sugerem que a energia no processo de irradiação rompe as insaturações ora estabelecidas com a formação do compósito e com isso há a ocorrência dos dois processos concorrentes: formação de ligações cruzadas para promover a reticulação do material e a degradação do material. 
O aumento da concentração da borracha EPDM para $5 \%$ causa um efeito de maior enegrecimento dos compósitos formados e isso se reflete na baixa percentagem de transmitância dos espectros (FIG. 21) em relação aos espectros dos compósitos com $1 \%$ de EPDM (FIG. 20).

Nos compósitos não irradiados PEAD virgem/ 5 \% EPDM ST e TT, bem como no PEAD rep./ 5 \% EPDM TT (FIG. 21a, 21b e 21c), o comportamento espectral é semelhante ao dos compósitos com $1 \%$ EPDM (ST e TT), onde não se observam diferenças entre os modos de tratamento do EPDM e indica que o aumento da concentração de insaturações no produto final, onde mesmo após sofrer reprocessamento, os dienos ainda estão presentes no EPDM.

Após o processo de irradiação, ainda na FIG. 21, o espectro desses compósitos apresenta:

a)

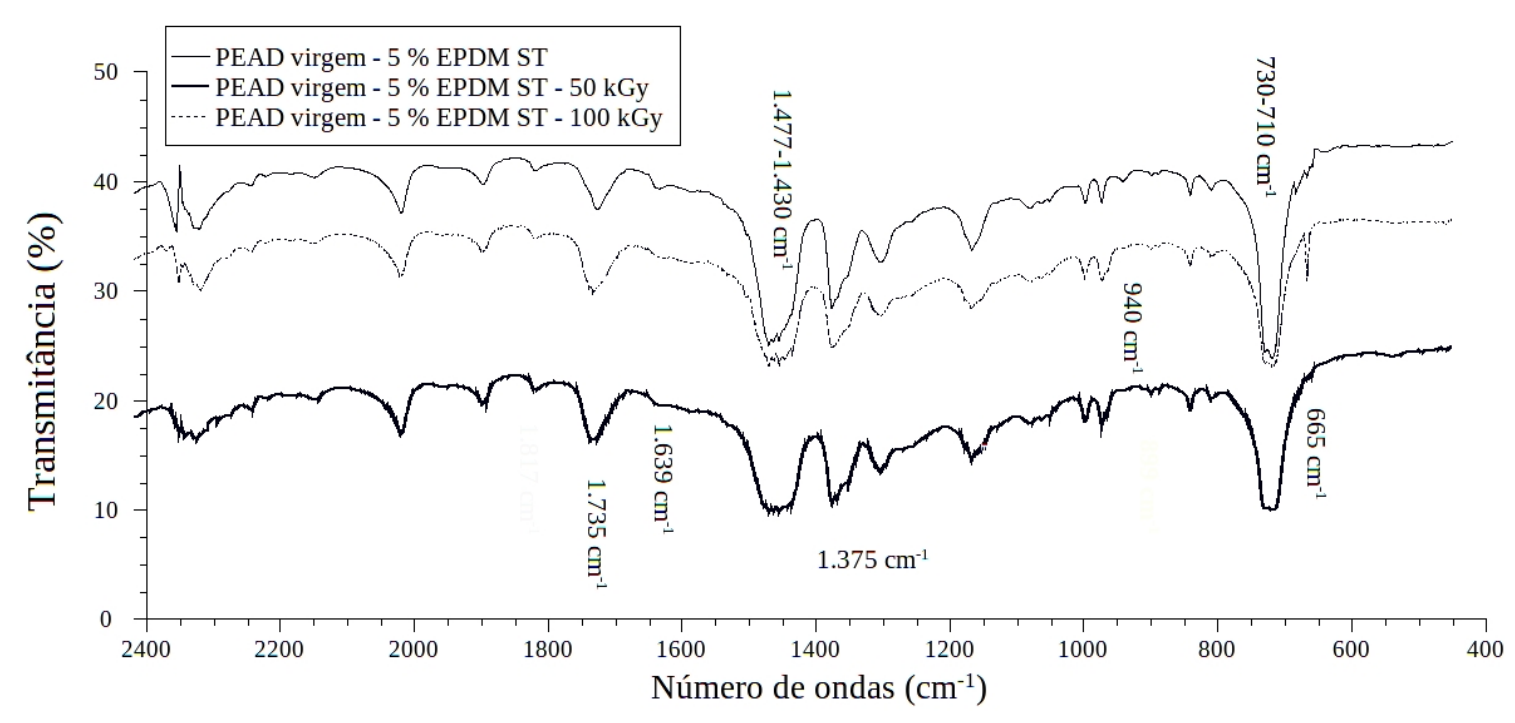

FIGURA 21: Espectros de infravermelho das amostras não irradiadas e irradiadas por feixe de elétrons, nas doses de 50 kGy e 100 kGy dos compósitos PEAD/5 \% EPDM a) ST e (continua). 
b)

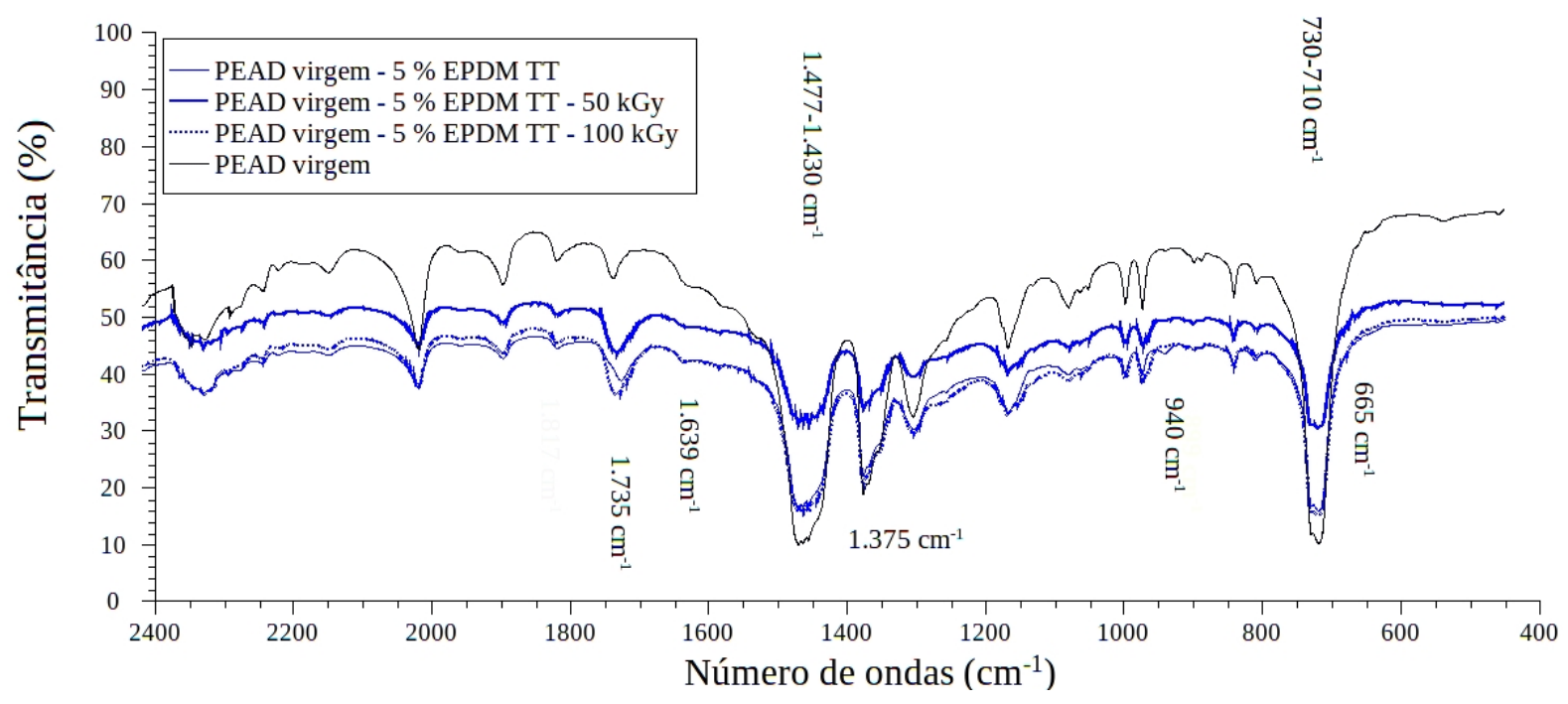

c)

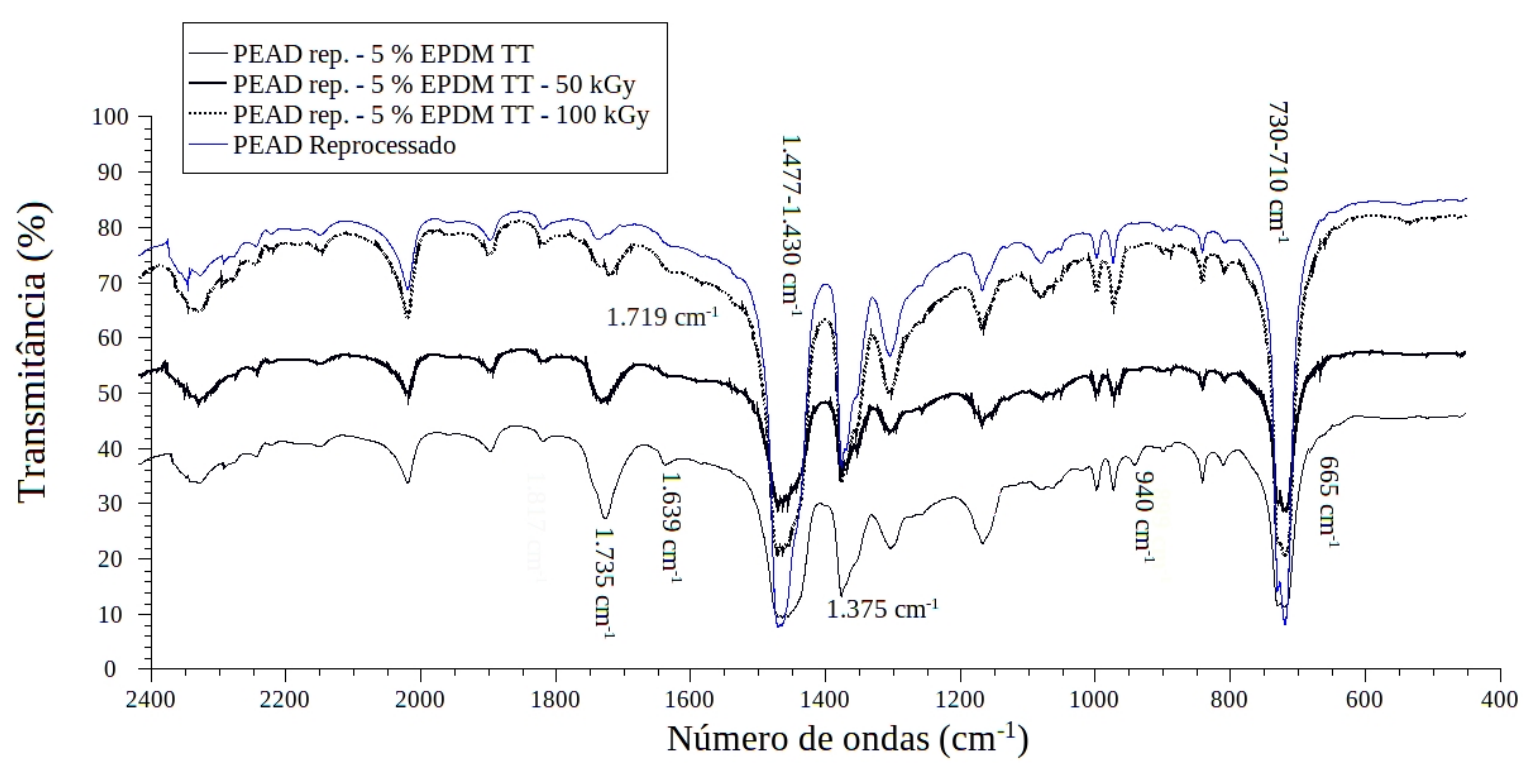

FIGURA 21: Espectros de infravermelho das amostras não irradiadas e irradiadas por feixe de elétrons, nas doses de 50 kGy e 100 kGy dos compósitos PEAD/5\% EPDM b) virgem TT. E c) reprocessado TT.

a) Desaparecimento da banda em $940 \mathrm{~cm}^{-1}$, o que sugere a ocorrência da reticulação e degradação simultaneamente;

b) A banda em $1.375 \mathrm{~cm}^{-1}$ apresenta-se menos intensa e mais larga em todas as doses absorvidas nos compósitos PEAD virgem/5 \% EPDM ST sugerindo a 
ocorrência de ramificação na cadeia devido ao processo de degradação promovido pela irradiação;

c) O comportamento da banda em $1.375 \mathrm{~cm}^{-1}$ descrito acima é verificado somente na dose absorvida de 50 kGy nos dois tipos de compósito (com ambos tipos de PEAD - virgem e reciclado) contendo 5 \% de EPDM TT, sendo que em $100 \mathrm{kGy}$ observa-se um comportamento oposto, onde a intensidade iguala-se ao do respectivo compósito não irradiado. A ocorrência desses distintos comportamentos sugere que em 100 kGy não ocorre aquela possível formação de ramificação na cadeia em decorrência da degradação por irradiação;

c) A banda em $1.735 \mathrm{~cm}^{-1}$ nos compósitos PEAD virgem $/ 5 \%$ de EPDM em ambos os tipos de tratamento não apresenta deslocamento em termos de frequência e a sua intensidade é semelhante à apresentada no espectro da matriz de PEAD virgem, sugerindo que a irradiação é responsável pela quebra das insaturações ora estabelecidas com a formação do compósito para promover os dois processos concorrentes: a reticulação do material e a sua degradação;

d) No compósito PEAD rep. /5 \% EPDM TT irradiado em 50 kGy a banda em $1.735 \mathrm{~cm}^{-1}$ é semelhante ao descrito acima, mas em $100 \mathrm{kGy}$ essa banda é menos intensa e verifica-se, ainda, a presença da banda em $1.715 \mathrm{~cm}^{-1}$, relativa à formação de carbonila devido ao processo de oxidação pela irradiação na presença de ar atmosférico.

Deste modo, o aumento da concentração de EPDM reprocessado implica a alteração em termos da estrutura molecular dos compósitos estudados, além de serem ressaltadas as diferenças na matriz polimérica de PEAD (virgem e reprocessado).

\subsubsection{Ensaios Mecânicos}

\subsubsection{Limite de resistência à tração}

O limite de resistência à tração no PEAD virgem (FIG. 22), foi verificado em torno de $24 \mathrm{MPa}$, que é um valor típico segundo a literatura (CALLISTER, 1991). Após o reprocessamento em 20 ciclos termocisalhantes, o limite de resistência à tração aumentou para um valor de cerca de $26 \mathrm{MPa}$, indicando que 
a reticulação promovida no reprocessamento do PEAD foi importante no aumento dessa característica mecânica. No entanto, nos compósitos o valor desse parâmetro foi semelhante ao do PEAD virgem, com exceção ao do compósito PEAD virgem/5 \% EPDM TT, onde esse parâmetro apresentou o menor valor.

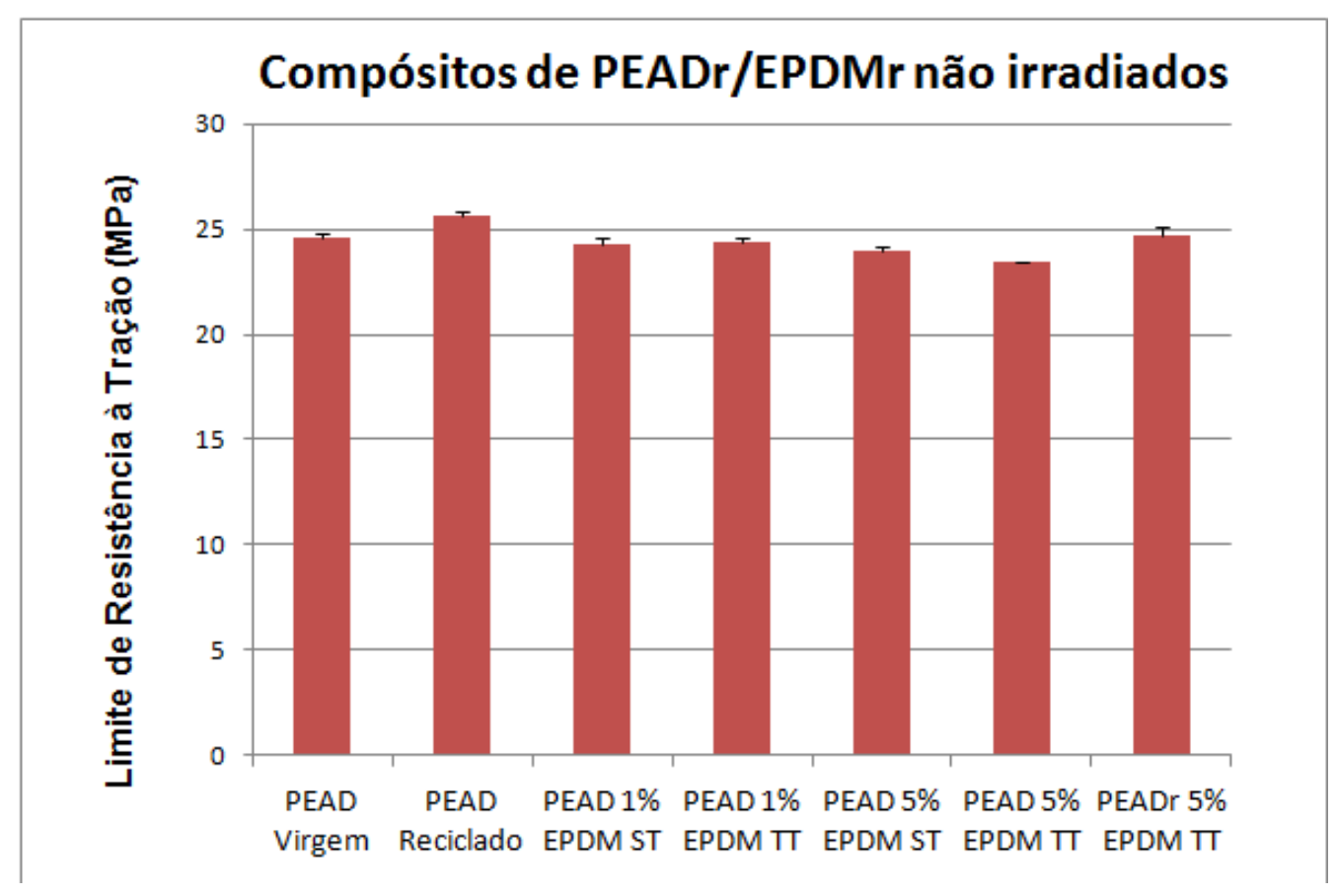

FIGURA 22: Limite de resistência à tração das amostras não irradiadas do PEAD virgem e PEAD reprocessado, e dos compósitos de PEAD/EPDM ST e TT.

Após a irradiação por feixe de elétrons em uma dose absorvida de 50 kGy (FIG. 23) as amostras de PEAD virgem e reprocessado apresentaram aumento do valor do limite de resistência à tração, sendo este o comportamento observado nas amostras dos compósitos com 1 \% de EPDM ST e TT) e na amostra do compósito PEAD reprocessado/5 \% EPDM TT, o que converge para o que foi verificado na calorimetria exploratória diferencial dessas amostras, onde a inserção da borracha EPDM em pequenas concentrações promove a reticulação do material, e no caso do compósito de PEAD reprocessado, onde a reticulação também foi verificada. 


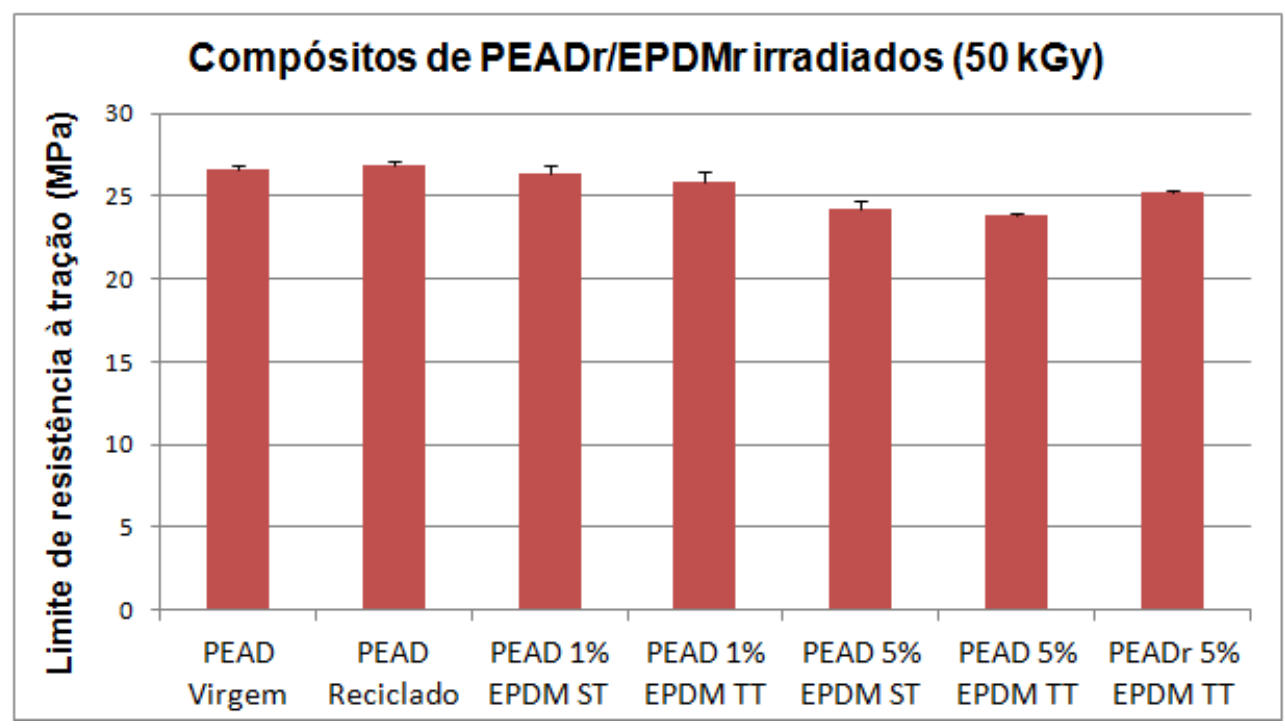

FIGURA 23: Limite de resistência à tração das amostras irradiadas por feixe de elétrons na dose de 50 kGy do PEAD virgem e reprocessado e dos compósitos de PEAD/EPDM ST e TT.

O aumento da dose absorvida para 100 kGy (FIG. 24), não apresenta alteração significativa do comportamento e dos valores do limite de resistência à tração das amostras em relação às irradiadas em 50 kGy. No caso das amostras dos compósitos PEAD virgem $/ 5$ \% de EPDM ST observa-se a diminuição destes valores, representando a perda dessa propriedade e, evidenciando a sua degradação durante o processo. 


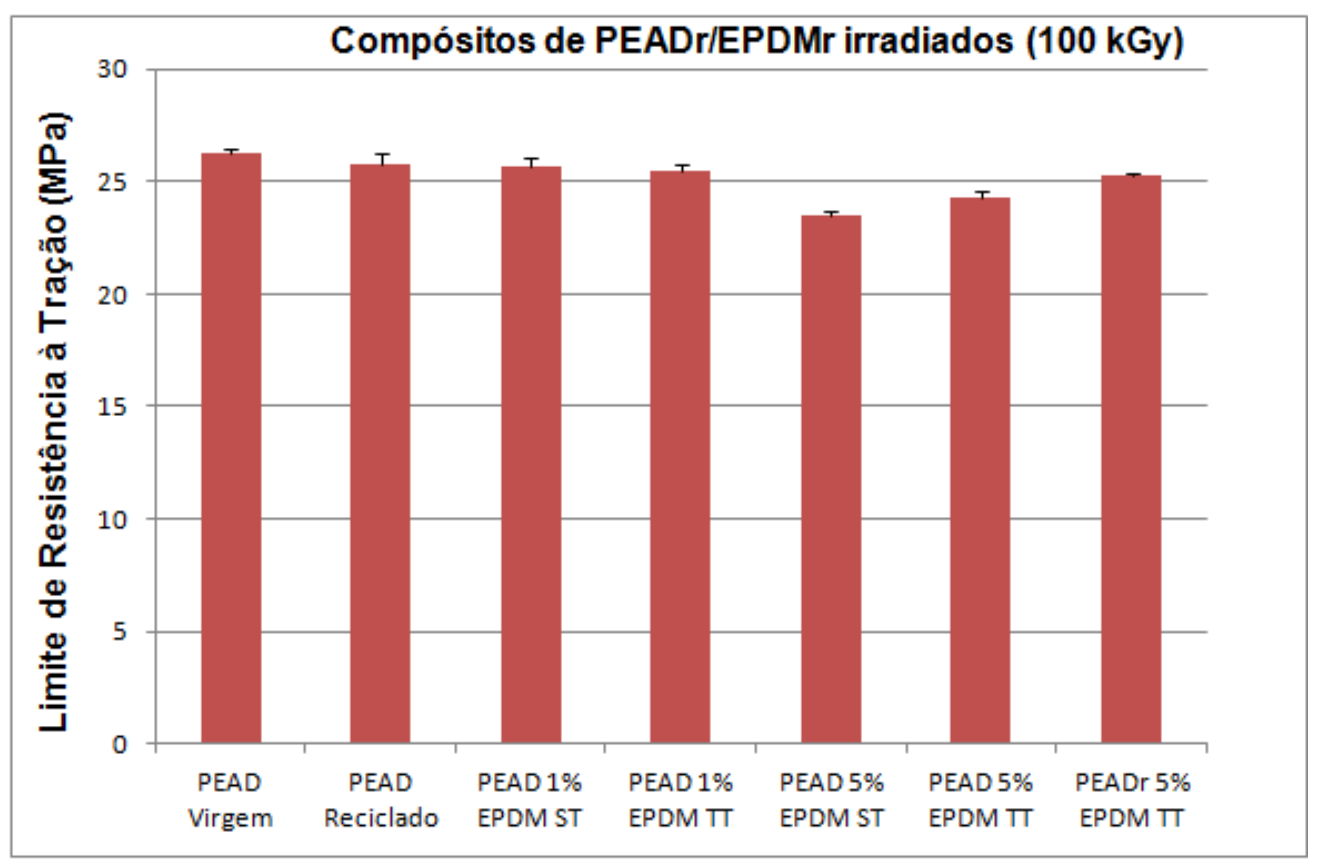

FIGURA 24: Limite de resistência à tração das amostras irradiadas por feixe de elétrons na dose de 100 kGy do PEAD virgem e reprocessado e dos compósitos de PEAD/EPDM ST e TT.

\subsubsection{Tensão na ruptura}

Os resultados do parâmetro mecânico tensão na ruptura das amostras não irradiadas são mostrados na FIG. 25. As amostras não irradiadas apresentaram valores semelhantes deste parâmetro (entre 11 e $13 \mathrm{MPa}$ ), sendo que o PEAD virgem registrou o maior valor. O mesmo comportamento verificado no parâmetro limite de resistência à tração é verificado aqui, onde as mesmas considerações são feitas. 


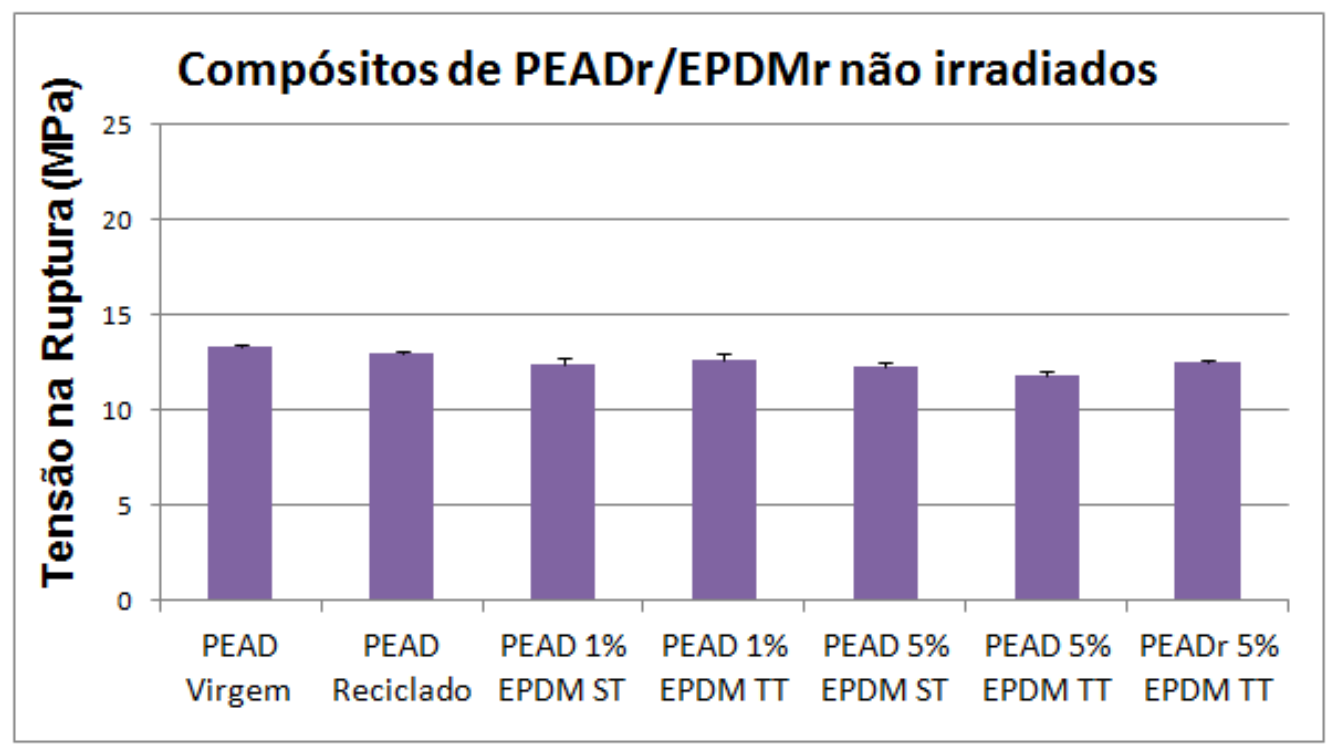

FIGURA 25: Tensão na ruptura das amostras não irradiadas do PEAD virgem e reprocessado e dos compósitos de PEAD/EPDM ST e TT.

Quando se aplica o processo de irradiação por feixe de elétrons na dose de 50 kGy (FIG. 26), observa-se que o PEAD virgem e o reprocessado apresentaram aumento nos valores desse parâmetro, ficando em torno de 14 MPa. Nas amostras dos compósitos, o PEAD com $1 \%$ de EPDM ST apresentou diminuição do valor desse parâmetro em relação à amostra não irradiada, porém o compósito com a mesma concentração do EPDM com tratamento térmico não apresentou alteração do valor. O aumento da concentração da borracha EPDM incidiu no aumento do valor nesse parâmetro quando os compósitos têm o PEAD virgem como componente principal, porém o compósito PEAD reciclado/5\% EPDM TT mostrou diminuição do valor desse parâmetro em comparação à mesma amostra não irradiada, o que sugere a sua degradação durante o processo de irradiação. Esse comportamento está relacionado à reticulação dos compósitos e converge para a discussão vista no item 5.3.2. 


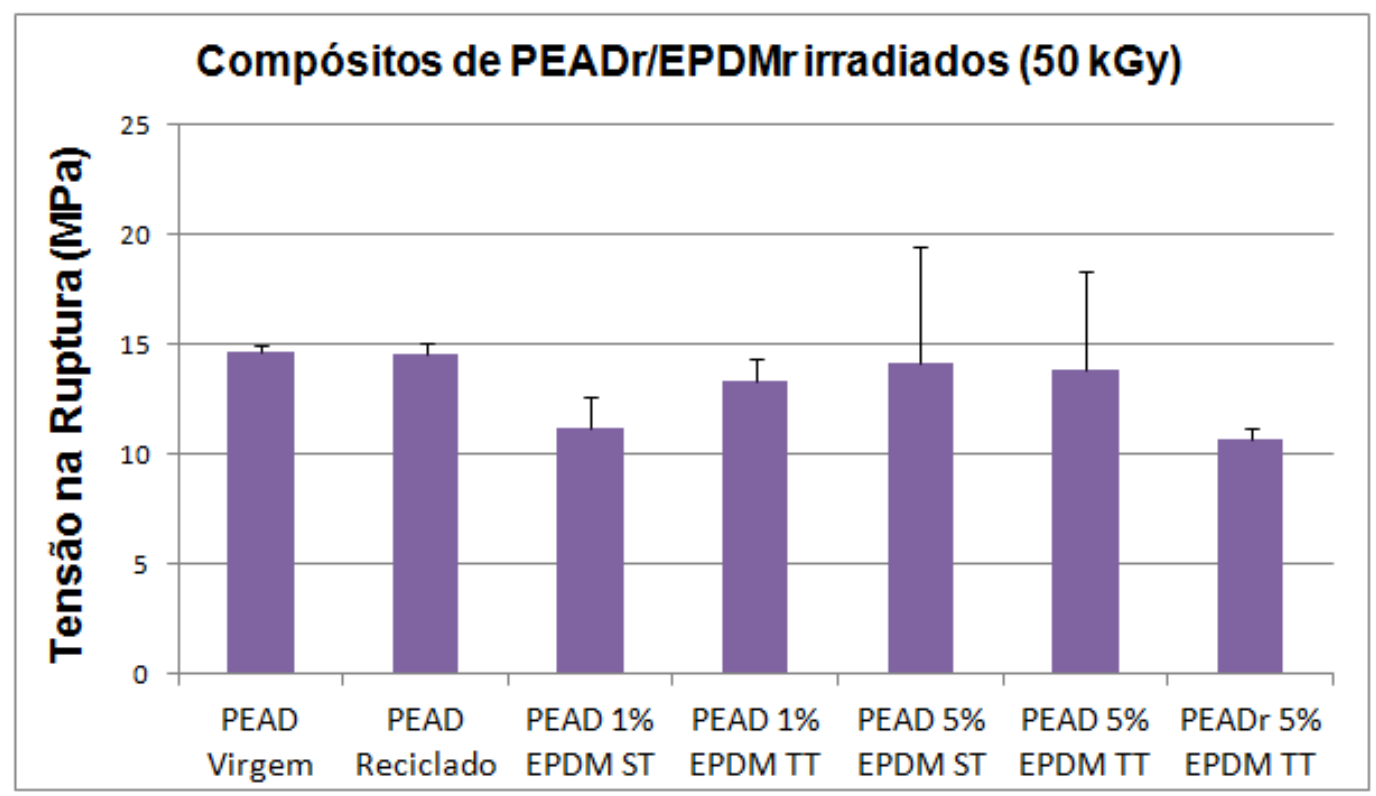

FIGURA 26: Tensão na ruptura das amostras irradiadas por feixe de elétrons na dose de 50 kGy do PEAD virgem e reprocessado e dos compósitos de PEAD/EPDM ST e TT.

Após o processo de irradiação na dose de 100 kGy (FIG. 27), observase que o valor da tensão na ruptura apresentou aumento (cerca de 16,5 $\mathrm{MPa}$ ) nas amostras do PEAD virgem e reciclado em relação àqueles verificados na menor dose. Nos compósitos observa-se que aqueles em que a borracha EPDM ST é usada, os valores do parâmetro medido diminuíram em relação ao observado em 50 kGy e é sempre menor em relação ao verificado para os demais compósitos nessa dose. As amostras contendo EPDM TT apresentaram os valores mais altos desse parâmetro em relação ao verificado em $50 \mathrm{kGy}$, destacando-se o compósito PEAD reciclado/5 \% EPDM TT, que apresentou o mais alto valor, inclusive em relação aos termoplásticos virgem e reprocessado. Nessa dose verifica-se a diferença entre o tipo de tratamento da borracha EPDM, o que influencia no grau de reticulação do produto final, como verificado e discutido no item 5.3.2. 


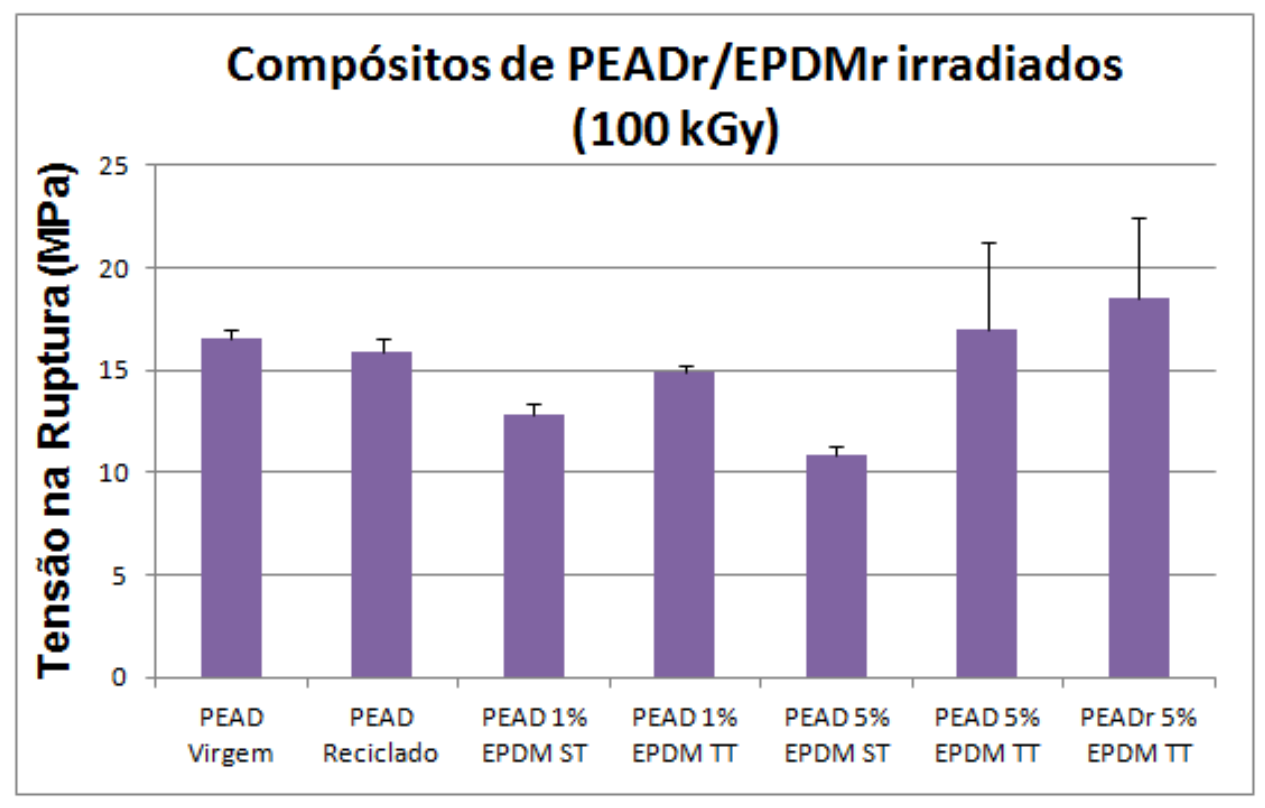

FIGURA 27: Tensão na ruptura das amostras irradiadas por feixe de elétrons na dose de 100 kGy do PEAD virgem e PEAD reprocessado e dos compósitos de PEAD/EPDM ST e TT.

\subsubsection{Resistência ao Impacto Izod}

A medida de resistência ao impacto das amostras não irradiadas é mostrada na FIG. 28.

Nessa série de medidas, o PEAD virgem apresentou um valor médio de $120 \mathrm{~J} / \mathrm{m}$ que é um valor alto (LANXESS, 2016). Sendo assim, na análise desse parâmetro será considerada somente a tendência do comportamento.

O PEAD reprocessado apresentou resistência ao impacto maior que o $P E A D$ virgem e essa tendência se deve à reticulação desse material conseguida durante os ciclos de termocisalhamento do termoplástico.

As amostras dos compósitos contendo $1 \%$ e $5 \%$ de EPDM ST apresentaram resistência ao impacto menor que os compósitos contendo EPDM $\mathrm{TT}$, o que está relacionado à reticulação dos mesmos. O compósito PEAD reprocessado/5 \% EPDM TT mostrou a menor resistência ao impacto. 


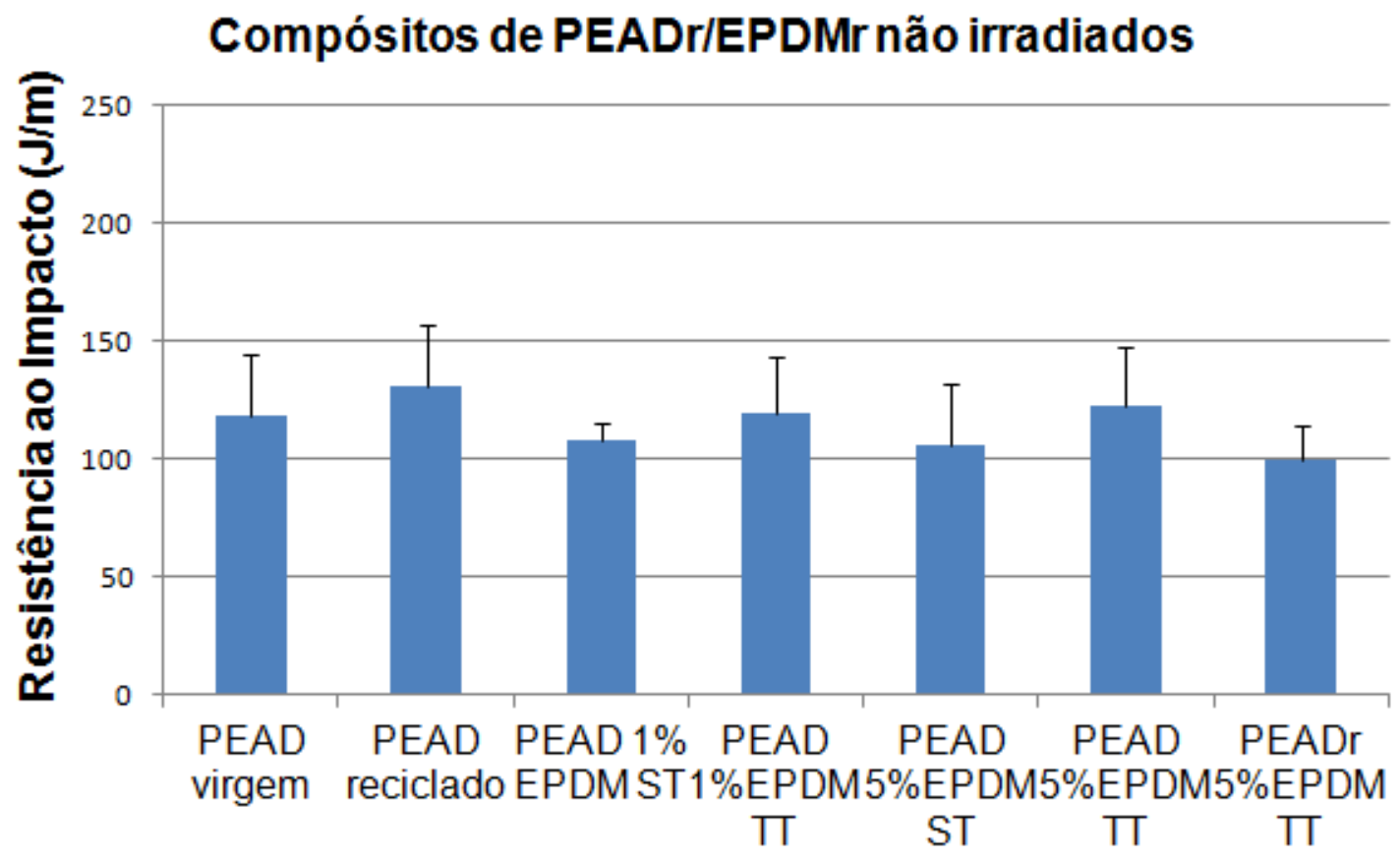

FIGURA 28: Resistência ao impacto das amostras não irradiadas do PEAD virgem e PEAD reprocessado e dos compósitos de PEAD/EPDM ST e TT.

O processo de irradiação por feixe de elétrons da dose absorvida de 50 kGy aplicado nas amostras (FIG. 29), mostra que o comportamento da resistência ao impacto acompanha o comportamento da $T_{f}$ verificada no item 5.3.2 nessa mesma dose, onde verifica-se o aumento da resistência ao impacto do PEAD virgem quando comparado ao mesmo parâmetro do PEAD reprocessado. A amostra PEADvirgem/1\% EPDM TT mostrou maior resistência ao impacto, o que indica a ocorrência de reticulação nessas condições, e as amostras contendo $5 \%$ de EPDM (com ou sem tratamento térmico) apresentaram diminuição desse parâmetro após a irradiação, indicando a degradação desse compósito nessas condições, refletindo na perda destas propriedades. 


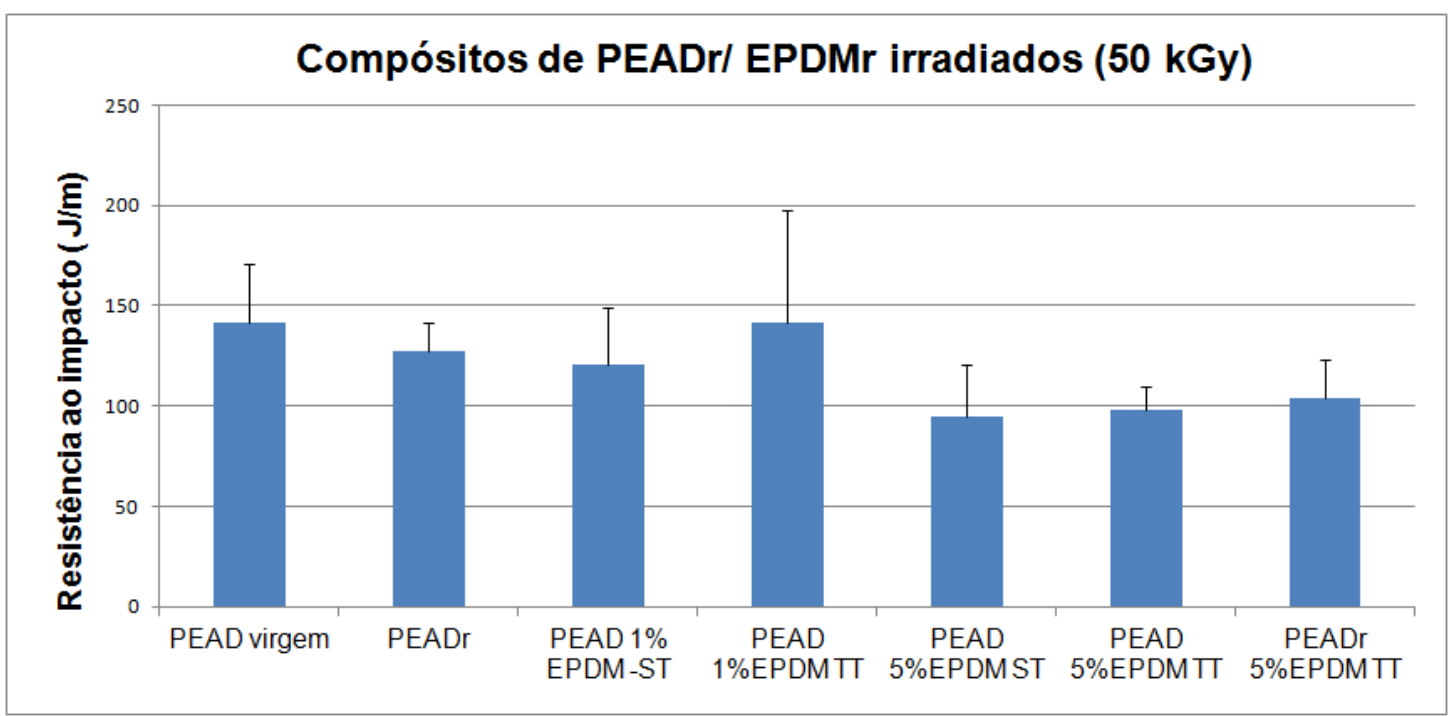

FIGURA 29: Resistência ao impacto das amostras irradiadas por feixe de elétrons na dose de 50 kGy do PEAD virgem e PEAD reprocessado e dos compósitos de PEAD/EPDM ST e TT.

Com o aumento da dose de irradiação (FIG. 30), mais uma vez, observa-se semelhança entre o comportamento da resistência ao impacto e da temperatura de fusão, o que sugere que o parâmetro mecânico depende do nível de reticulação das amostras. Em 100 kGy é o PEAD reprocessado que apresenta maior resistência ao impacto quando comparado ao PEAD virgem; dentre os compósitos é a amostra do PEAD virgem/1\% EPDM ST que apresenta a maior resistência ao impacto, sendo que os outros compósitos apresentam decréscimo nesse parâmetro com o aumento da concentração de EPDM e com a borracha apresentando tratamento térmico, indicando a degradação dessas amostras durante o processo de irradiação. 


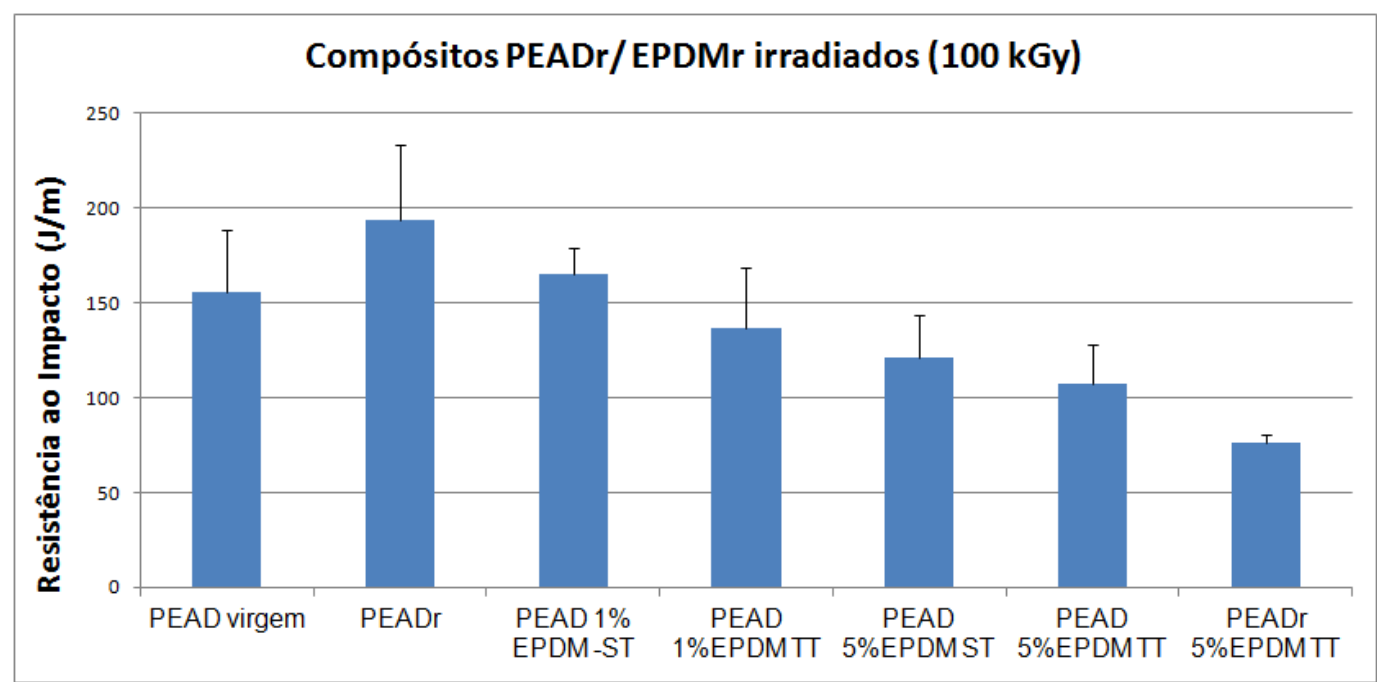

FIGURA 30: Resistência ao impacto das amostras irradiadas por feixe de elétrons na dose de 100 kGy do PEAD virgem e PEAD reprocessado e dos compósitos de PEAD/EPDM ST e TT.

\subsubsection{Ensaio de Dureza (Shore D)}

Segundo o ensaio de dureza das amostras não irradiadas (FIG. 31), pode-se observar que o PEAD reprocessado é mais resistente à penetração que o PEAD virgem e esta característica está relacionada à reticulação do material. Esse parâmetro medido nos compósitos é sempre menor que nos termoplásticos virgem e reprocessado e, além disso, mostra que a resistência à penetração é maior quando o compósito tem o EPDM ST na composição. O compósito PEADreprocessado/5 \% EPDM TT apresentou alta dureza, cujo valor é semelhante ao do compósito PEAD virgem/1 \% EPDM ST, e mostra que sua alta resistência a penetração está relacionada com seu grau de cristalinidade.

Estes resultados são opostos aos observados para a resistência ao impacto mostrados na FIG. 28, e são conhecidos na literatura (CALLISTER, 1991), onde amostras com baixa dureza, ou seja, amostras dúcteis, apresentam maior resistência ao impacto; amostras com alta dureza apresentam menor resistência ao impacto por serem frágeis. 


\section{Compósitos de PEADr/EPDMr não irradiados}

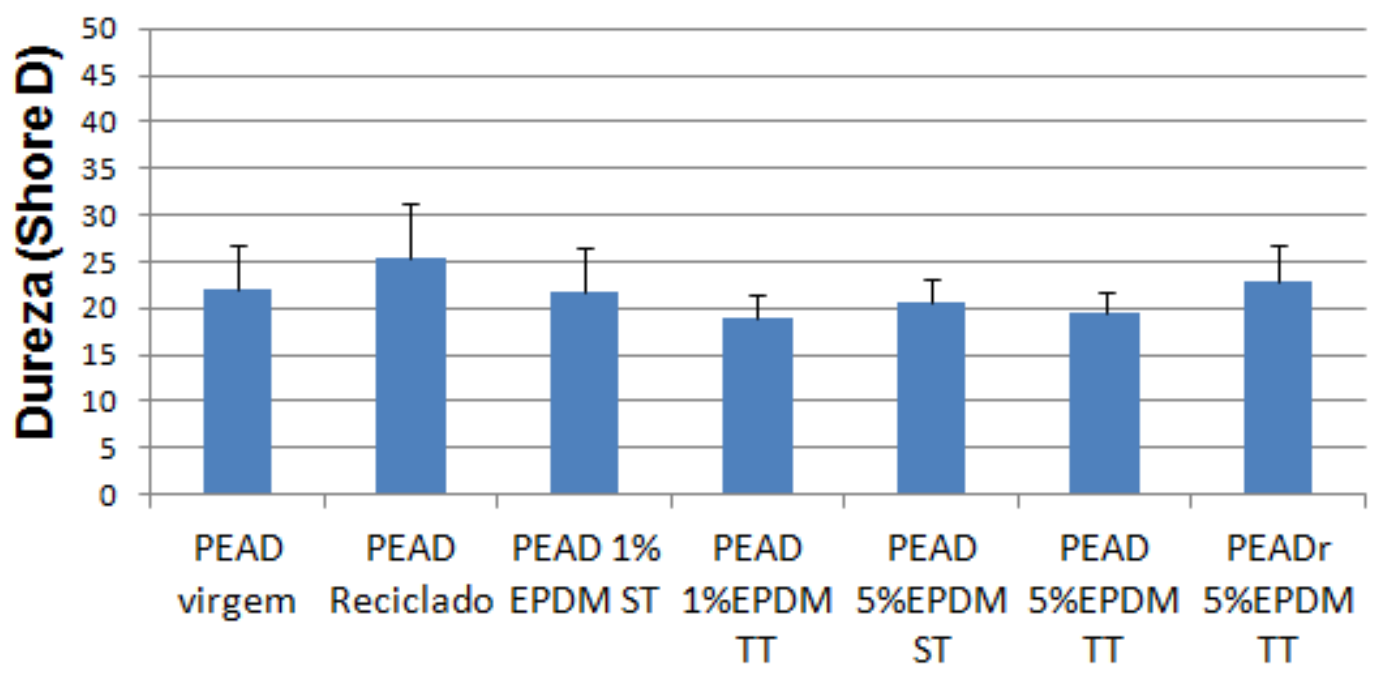

FIGURA 31: Medida de dureza das amostras não irradiadas do PEAD virgem e PEAD reprocessado e dos compósitos de PEAD/EPDM ST e TT.

Com o processo de irradiação por feixe de elétrons na dose absorvida de 50 kGy (FIG. 32), o PEAD reprocessado apresentou maior resistência à penetração, quando comparado ao PEAD virgem. Nos compósitos, essa condição de irradiação mostrou que as amostras contendo EPDM TT apresentaram maior dureza, sendo que esse parâmetro aumenta com o aumento da concentração desta borracha; a amostra do compósito PEAD virgem/5 \% EPDM TT apresentou o maior valor desse parâmetro nesta condição. 


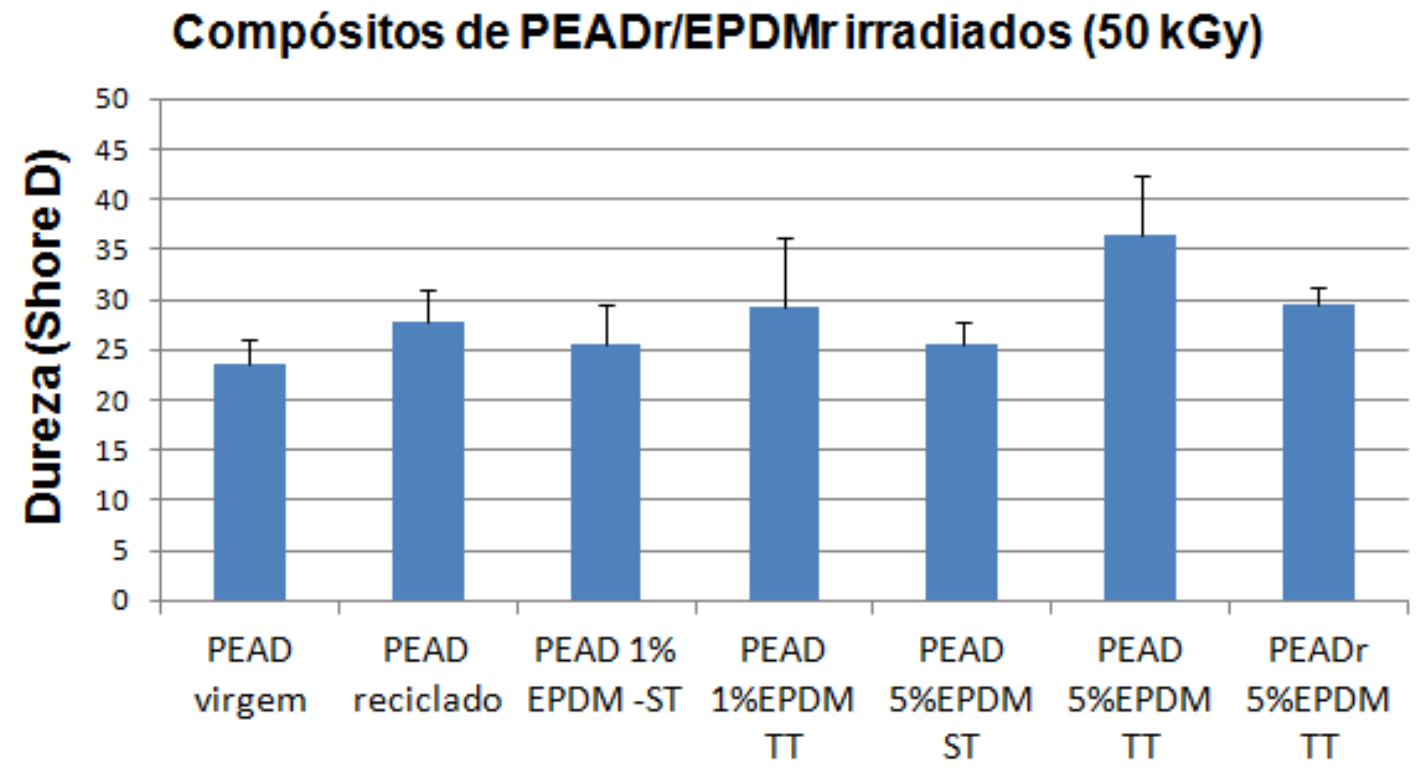

FIGURA 32: Medida de dureza das amostras irradiadas por feixe de elétrons na dose de 50 kGy do PEAD virgem e PEAD reprocessado e dos compósitos de PEAD/EPDM ST e TT.

O aumento da dose absorvida em 100 kGy (FIG. 33), mostra que a dureza aumentou nas amostras dos compósitos em relação a esse parâmetro medido nos termoplásticos virgem e reprocessado. Esse comportamento é o oposto do verificado para a resistência ao impacto na mesma dose para as amostras compósitas. 
Compósitos de PEADr/EPDMr irradiados (100 kGy)

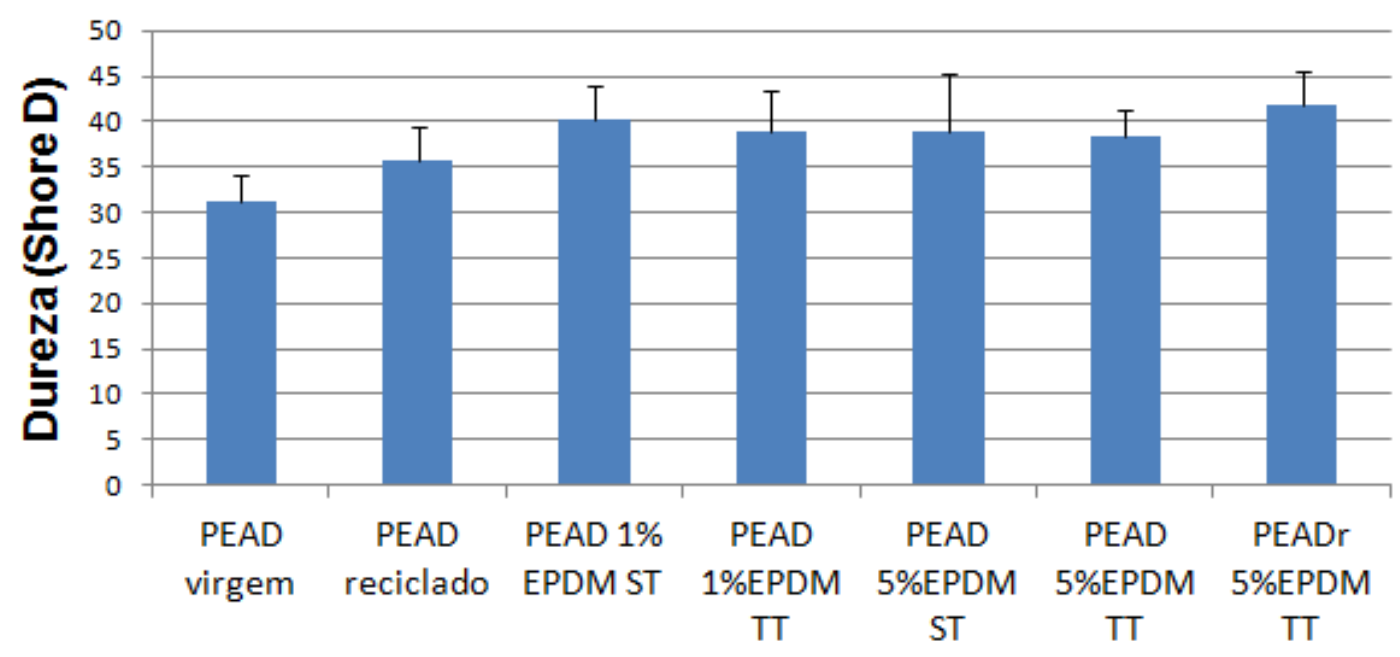

FIGURA 33: Medida de dureza das amostras irradiadas por feixe de elétrons na dose de 100 kGy do PEAD virgem e PEAD reprocessado e dos compósitos de PEAD/EPDM ST e TT.

\subsubsection{Microscopia Eletrônica de Varredura (MEV)}

As imagens obtidas por MEV mostram as características morfológicas das amostras analisadas.

O PEAD reprocessado 20 vezes (FIG. 34a), apresenta regiões com uma estrutura fibrosa, o que sugere ao material o incremento de sua resistência mecânica.

A FIG. 34b mostra o compósito PEAD virgem/5 \% EPDM TT, onde se observa que na superfície após a fratura predomina um aspecto homogêneo, não havendo heterogeneidades devido à inserção do pó de borracha, indicando que a compatibilização do material foi efetiva. 


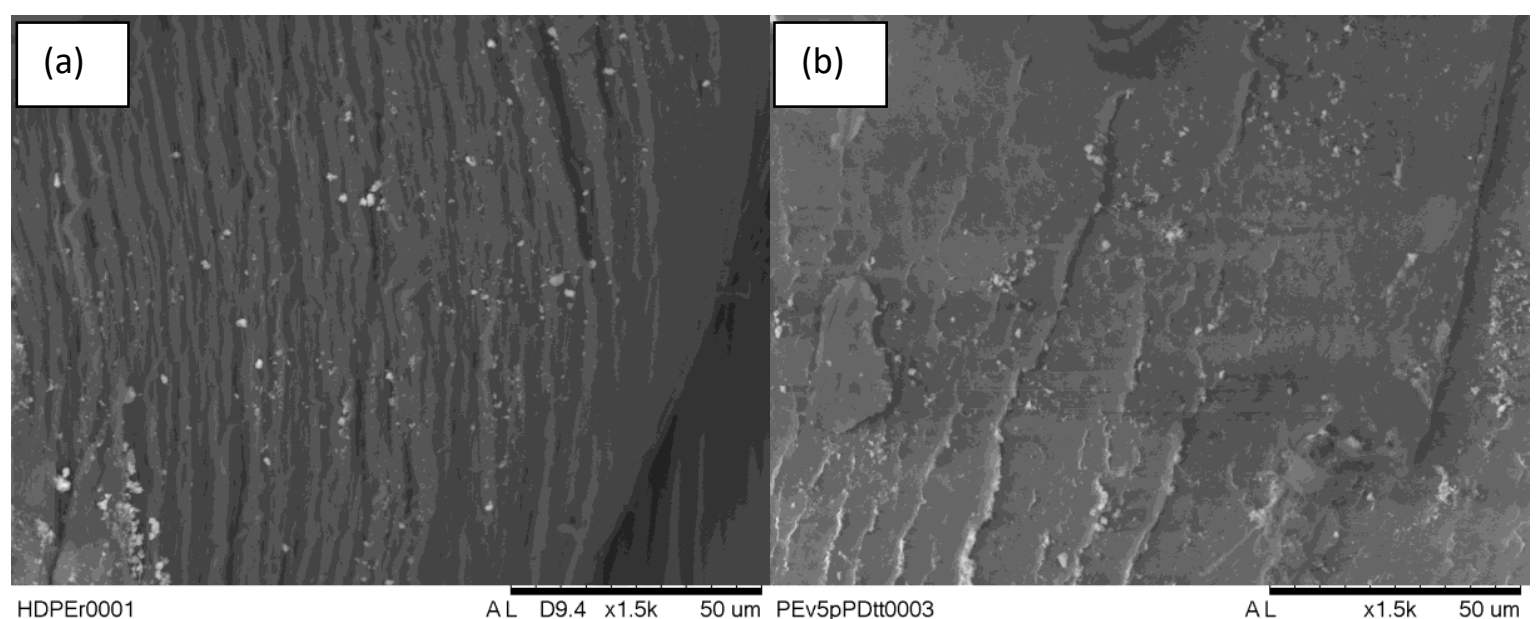

FIGURA 34: Micrografias eletrônicas de varredura das amostras de a) PEAD reprocessado e b) compósito PEAD virgem/5 \% EPDM TT.

Nas FIG. 35a e 35b observam-se distintas regiões do compósito PEAD reprocessado/5 \% EPDM TT. No canto inferior direito da micrografia 35a há um fragmento da borracha dispersa na matriz do PEAD reprocessado, onde se notam os dois materiais em uma mesma orientação, sem heterogeneidades topográficas e compatibilizadas na mistura.

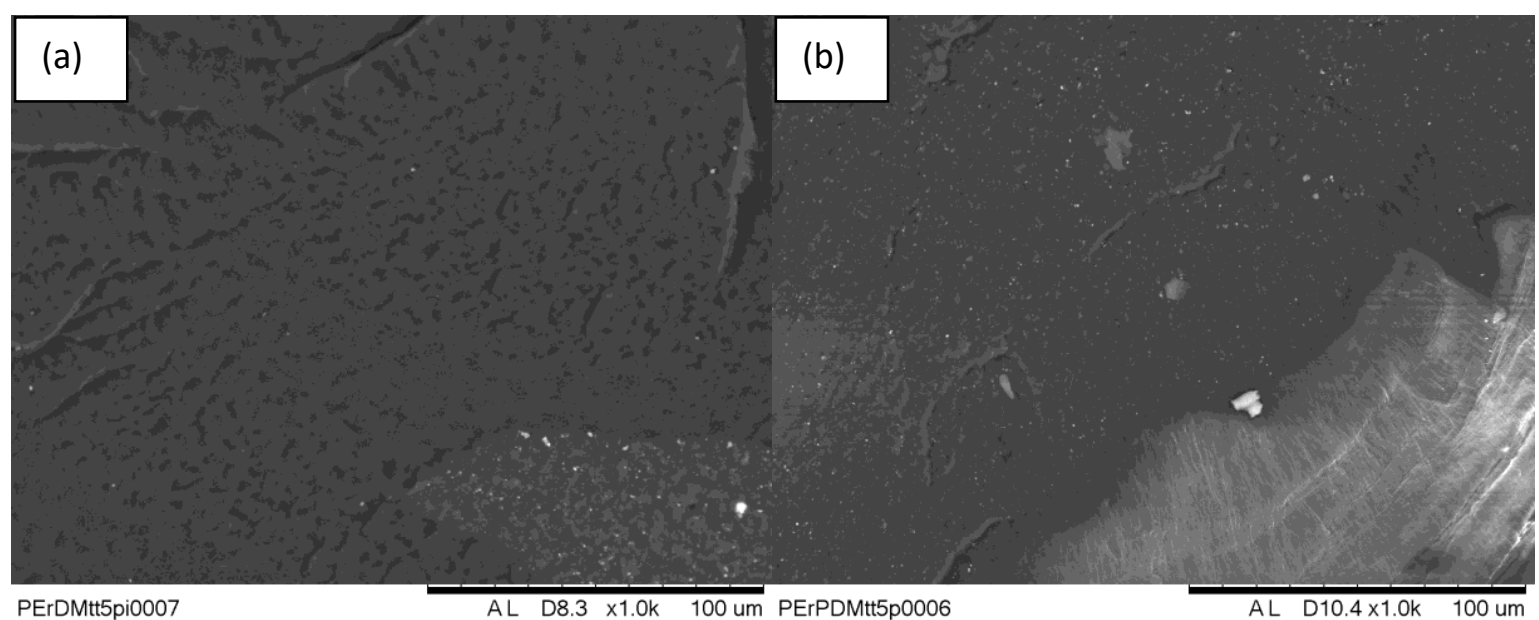

FIGURA 35: (a) e (b) PEADr com 5\% de EPDM com tratamento térmico. 


\section{CONCLUSÕES}

Neste trabalho foi realizada a desvulcanização da borracha de EPDM, que por si só é um compósito formado não só pelo EPDM, como também basicamente por óleos minerais, enxofre e/ou tiocompostos orgânicos e outros agentes de reticulação e cargas inorgânicas, como negro de fumo e sais inorgânicos. A desvulcanização foi obtida por irradiação sob aquecimento simultâneo, onde se observou a diminuição da dureza do material, e também por envelhecimento térmico em 7 dias de exposição à temperatura de $100 \stackrel{\circ}{\circ}$, onde o material inicial perde o óleo que o constitui além de não apresentar o estágio de degradação das ligações de enxofre. Esse último processo é mais atraente, apresentando-se como uma forma mais econômica quando se visa a sua utilização nas pequenas e médias indústrias.

Além disso, o PEAD virgem foi reprocessado até 20 vezes sob a ação termocisalhante de uma extrusora. $\mathrm{O}$ reprocessamento promoveu processos de degradação e reticulação simultâneos, cujo efeito macroscópico foi evidenciado pelo aumento da temperatura de fusão e dos parâmetros mecânicos limite de resistência à tração e resistência ao impacto. A submissão desse material ao processo de irradiação permitiu o aumento do grau de cristalinidade e resistência ao impacto dependendo da dose de radiação absorvida.

Finalmente, obtiveram-se compósitos de PEAD (virgem e PEAD reprocessado) com EPDM tratado e não tratado termicamente. Observou-se que a compatibilização da mistura é importante, o que gera um material sem heterogeneidades morfológicas. A adição de EPDM em baixas concentrações (1 $\%$ e $5 \%$ ) é fundamental na promoção da reticulação do material, o que vai influenciar nas características mecânicas do material e consequentemente, no seu uso. O processo de irradiação é fundamental nesse sentido, onde o compósito constituído pelos componentes degradados, o PEAD reprocessado/5 \% EPDM TT apresentou maior valor de tensão na ruptura quando irradiado em 100 kGy e os compósitos PEAD virgem/1 \% EPDM (ST e TT) apresentaram os maiores valores de resistência ao impacto, dependendo da dose de radiação absorvida. 


\section{TRABALHOS FUTUROS}

Como perspectiva para trabalhos futuros destaca-se:

- $\quad$ O estudo estatístico sobre a concentração limite da borracha EPDM à matriz do termoplástico PEAD (virgem e reprocessado) sem a perda dos efeitos de compatibilização e características mecânicas e térmicas;

- A produção deste tipo de compósito, utilizando o PEAD reciclado comercialmente como forma de destinar os resíduos da indústria de plástico em processos que obtenham materiais com resistência mecânica e características térmicas específicas a um determinado uso. 


\section{REFERÊNCIAS BIBLIOGRÁFICAS}

ABRELPE - Panorama dos Resíduos Sólidos no Brasil. Brasil, 2014. Disponível em: < http://www.abrelpe.org.br/Panorama/panorama2014.pdf>. Acesso em: 12 dez. 2016.

AMERICAN SOCIETY FOR TESTING AND MATERIALS. Standard Test Methods for Determining the Izod Pendulum Impact Resistance of Plastics. United States of America, 2010. (ASTM D 256 - 10)

AMERICAN SOCIETY FOR TESTING AND MATERIALS. Standard Test Method for Tensile Properties of Plastics. United States of America, 2014. (ASTM D 638 $-14)$

AMERICAN SOCIETY FOR TESTING AND MATERIALS. Standard Test Method for Rubber Property_Durometer Hardness. United States of America, 2015. (ASTM D 2240 - 15)

BNDES - BANCO NACIONAL DE DESENVOLVIMENTO SOCIAL. Setorial, n. 38, 131-172, set. 2013. Disponível em: $<$ https://web.bndes.gov.br/bib/jspui/bitstream/1408/1401/1/BS\%2038 final\%20ABD.pdf>. Acesso em: 09 out. 2016.

BHOWMICK, A.K.; STEPHENS, H.L. Handbook of Elastomers. 2. ed. New York, N.Y.: Marcel Dekker, 2001.

BRASIL. Lei no 12305/2010 de 02 de agosto de 2010. Institui a Política Nacional de Resíduos Sólidos; altera a Lei oㅜ 9.605 de 12 de fevereiro de 1998; e dá outras providências. Diário Oficial da República Federativa do Brasil, Brasília, DF, 03 ago. $2010 . \quad$ Disponível em: <http://www.mma.gov.br/port/conama/legiabre.cfm?codlegi=636>. Acesso em: 08 out. 2016.

BRASIL. Resolução CONAMA № 420/2009 de 28 de dezembro de 2009. "Dispõe sobre critérios e valores orientadores de qualidade do solo quanto à presença de substâncias químicas e estabelece diretrizes para o gerenciamento ambiental de áreas contaminadas por essas substâncias em decorrência de atividades antrópicas." Diário Oficial da República Federativa do Brasil, Brasília, DF, 30 dez. $2009 . \quad$ Disponível em: $<$ http://www.mma.gov.br/port/conama/legiabre.cfm?codlegi=620>. Acesso em: 09 out. 2016.

BRASKEM. Extrusão de Filme: polietileno e polipropileno. São Paulo, 2008. Disponível em: <http://www.braskem.com/catalogo2016mai16/>. Acesso em: 09 out. 2016. (Catálogo comercial) 
BURROWES, G. Industrial Rubber Products. In: RODGERS, B. (Ed.). Rubber Compounding: Chemistry and Applications. Nova lorque, N.Y.: CRC, 2016.

CALLISTER JR, W.D. Materials Science and Engineering: an introduction. 2. ed. Nova lorque, N.Y.: Wiley, 1991.

CAMACHO, W.; KARLSSON, S. Assessment of thermal and thermo-oxidative stability of multi-extruded recycled PP, HDPE and a blend therof. Polymer Degradation and Stability, v. 78, p. 385-391, 2002.

CAÑAVATE, J.; CASAS,P.; COLOM, X.; NOGUÉS, F. Formulations for thermoplastics vulcanizates based on high density polyethylene, ethylenepropylene-diene monomer, and ground tire rubber. Journal of Composite Materials, v. 45, p. 1189-1200, 2011.

CÂNDIDO, G.M.; ALMEIDA, S.F.M. Processamento de Laminados de Compósitos Poliméricos Avançados com Bordas Moldadas. Polímeros: Ciência e Tecnologia, v. 10, p. $31-41,2000$.

CANEVAROLO JR, S.V. Técnicas de Caracterização de Polímeros. 1. ed. São Paulo, S.P.: Artliber, 2004.

CANEVAROLO JR, S.V. Ciência dos Polímeros: Um texto básico para tecnólogos e engenheiros. 3. ed. São Paulo, SP: Artliber, 2010.

CÉSPEDES, R.I.N.; GÁMEZ, J.F.H.; VELÁZQUEZ, M.G.N.; BELMONTES, F.A.; LEÓN, R.E.D.; FERNÁNDEZ, O.S.R.; ORTA, C.A.A.; HERNÁNDEZ, E.H. Thermoplastic elastomers based on high density polyethylene, ethylenepropylene-diene terpolimer, and ground tire rubber dynamically vulcanized with dicumyl peroxide. Journal of Applied Polymer Science, v. 131, p.1-8, 2014.

CHARLESBY, A. Effect of high energy radiation on long chain polymers. Nature, v. 171, n. $167,1953$.

CHARLESBy, A. Atomic Radiation and Polymers. 1. ed. Los Angeles, CA: Pergamon, 1960.

CHOI, S.; KWON, H.; KIM, Y.; BAE, J.W.; KIM, J. Characterization of maleic anhydride-grafted ethylene-propylene-diene terpolymer (MAH-g-EPDM) based thermoplastic elastomers by formation of zinc ionomer. Journal of Industrial and Engineering Chemistry, v. 19, p. 1990-1995, 2013.

CONTAT-RODRIGO, L.; RIBES-GREUS, A.; IMRIE, C.T. Characterization by thermal analysis of high density polyethylene/polypropylene blends with enhanced biodegradability. Journal of Applied Polymer Science,v. 86, p. 174-185, 2002. 
COUTINHO, F.M.B.; MELLO, I.L., SANTA MARIA, L.C. Polietileno: principais tipos, propriedades e aplicações. Polímero: Ciência e Tecnologia, v. 13, p. 1-13, 2003.

CZVIKOVSZKY, T. Expected and unexpected achievements and trends in radiation processing of polymers. Radiation Physics and Chemistry, v. 67, p. 437, 2003.

DENG, J.; HE, Q.; WU, Z.; YANG, W. Using glycidil metacrilate as cross-linking agent to prepare thermosensitive hydrogels by a novel one-step method. Journal of Polymer Science: Part A: Polymer Chemistry, v. 46, p. 2193-2201, 2008.

DEVI, R.R.; MAJI, T.K. Chemical modification of simul wood with styreneacrylonitrile copolymer and organically modified nanoclay. Wood Science and Technology, v. 46, p. 299-315, 2012.

EDRA ECO SISTEMAS - Reciclagem de borracha. Disponível em: $<$ http://www.edraecosistemas.com.br/borracha moidas. Acesso em: 10 out. 2016.

EPACHER, E.; TOLVÉTH, J.; STOLL, K.; PUKÁNSZKY, B. Two-step degradation of high density polyethylene during multiple extrusion. Journal of Applied Polymers, v. 74, p. 1596-1605, 1999.

FERREIRA, M.S., SARTORI, M.N., OLIVEIRA , R.R., GUVEN, O., MOURA, E.A.B., Short vegetal-fiber reinforced HDPE-A study of electron-beam radiation treatment effects on mechanical and morphological properties. Applied Surface Science, v. 310, p. 325-330, 2014.

FINK, J.K. Reactive Polymers Fundamentals and Application: A Concise Guide to Industrial Polymers. 2. ed. Waltham, MA.: Elsevier, 2013.

FINUCANE, E.W. Definitions, Conversions, and calculations for Occupacional Safety and Health Professionals. 2. ed. Boca Raton, FL: CRC, 2006.

FUKOMORI, K.; MATSUSHITA, M.; OKAMOTO, H.; SATO, N.; SUZUKI, Y.; TAKEUCHI, K. Recycling technology of tire rubber. JSAE Review, v. 23, p. 259264, 2002.

THE ECONOMIST. Gas Works. Jul. 2012. Disponível em: $<$ http://www.economist.com/sites/default/files/20120714 natural gas.pdf $>$. Acesso em: 09 out. 2016.

HASSAN, M.; ALY, R.O.; AAL, S.E.A.; EL-MASTRY, A.M.; FATHY, E.S. Mechanochemical devulcanization and gamma irradiation of devulcanized waste rubber/high density polyethylene thermoplastic elastomer. Journal of Industrial and Engineering Chemistry, v. 19, p. 1722-1729, 2013. 
HENDGES, A. S. Brasil se destaca no reuso do PET. Revista Cidadania \& Meio Ambiente. v.9, n. 52, 2014.

KARPELES, R.; GROSSI, A.V. EPDM Rubber Technology. In: BHOWMICK, A. K.; STEPHENS, H.L. (Ed.). Handbook of Elastomers. New York, N.Y.: Marcel Decker, 2001. 2. ed. p. 845-876.

KONING, C.; VAN DUIN, M.; PAGNOULLE, C.; JEROME, R. Strategies for compatibilization of polymers blends. Progress in Polymer Science, v. 23, p. 707-757, 1998.

LANXESS. Produtos, Folha de dados. In: Portal LANXESS. Disponível em: <http:/ www.lanxess.com.br > . Acesso em: 06 out. 2016.

LEXMARK INTERNATIONAL, INC. B. P. Livengood; B. W. Baird; G. P. Marshall. Reactive compatibilization of polymeric components such as siloxane polymers with other resins. US Patent 6544710, 8 abr. 2003.

LI, C., ZHANG, Y., ZHANG, Y., Melt grafting of maleic anhydride onto low-density polyethylene/polypropylene blends. Polymer Testing, v. 22 p. 191-195, 2003.

LIU, J.; LIU, P.; ZHANG, X.; LU, P.; ZHANG, X.; ZHANG, M. Fabrication of magnetic rubber composites by recycling waste rubber powders via a microwaveassisted in situ surface modification and semi-devulcanization process. Chemical Engineering Journal, v. 295, p. 73-79, 2016.

MACHADO, L.D.B.; MATOS, J.R. Análise térmica diferencial e calorimetria exploratória diferencial. In: CANEVAROLO JR, S.V. (Ed.). Técnicas de Caracterização de Polímeros. 1. ed. São Paulo, S.P.: Artliber, p. 229, 2004.

MATOS, J.R.; MACHADO, L.D.B., Análise térmica - Termogravimetria. In: CANEVAROLO JR, S.V. (Ed.). Técnicas de Caracterização de Polímeros. 1. ed. São Paulo, S.P.: Artliber, p. 209, 2004.

MANGARAJ, D. Rubber recycling by Blending with Plastics. In:

SADHAN, K. De; ISAYEV, A.I.; KHAIT, K. (Ed.). Rubber Recycling. Boca Raton, FL.: CRC, 2005.

MANO, E. B. Meio Ambiente, Poluição e Reciclagem. 1 ed. São Paulo, SP: Edgard Blücher, 2005.

MESQUITA, F.A. Modificação das propriedades do polietileno de alta densidade por diferentes condições de extrusão. 2010. Dissertação (Mestrado) - Escola Politécnica da Universidade de São Paulo, São Paulo.

MOTHÉ, C.G.; AZEVEDO, A.D. Análise Térmica de Materiais. 1. ed. São Paulo, S.P.: leditora, 2002. 
OLABISI, O. Polyolefins. In: OLABISI, O.; ADEWALE, K. Handbook of Thermoplastics. New York, N.Y.: CRC, 2015. p. 2-3.

PISTOR, V.; ORNAGHI, F.G.; FIORIO, R.; ZATTERA, A.J.; OLIVEIRA, P.J.; SCURACCHIO, C.H. Desvulcanização do resíduo de terpolímero de etilenopropileno-dieno (EPDM-r) por micro-ondas. Polímeros, v. 20, n. 3, p. 165-169, 2010.

PIVA, A.M.; WIEBECK, H. Reciclagem do Plástico. São Paulo, SP.: Artliber, 2004.

RODGERS, B.; D'CRUZ, B. Recycling of Rubber. In: RODGERS, B. Rubber Compounding: Chemistry and Applications. 2. ed. New York, N.Y.: CRC, 2015. p. 523-534.

SADHAN, K. De; ISAYEV, A.I.; KHAIT, K. Rubber Recycling. Boca Raton, FL.: CRC, 2005.

SANTOS, R.P.; JUNIOR, M.S.O; MATTOS, E.C.; DINIZ, M.F.; DUTRA, R.C.L. Caracterização por FT-IR da Superfície de Borracha EPDM tratada via plasma por micro-ondas. Polímeros, v. 22, n. 5, p. 440-446, 2012.

SCHEIRS, J.; BIGGER, S.W.; BILLINGHAM, N.C. Effect of chromium on the oxidative pyrolysis of gas-phase high-density polyethylene as determined by dynamic thermogravimetry. Polymer Degradation and Stability, v. 38, p. 139145, 1992.

SHARPATYI, V.A. Radiation Chemistry of Biopolymers. Boca Raton, FL: CRC, 2006.

SILVERSTEIN, R.M.; BASSLER, G.C.; MORRIL, T.C. Identificação Espectrométrica de Compostos Orgânicos. 3. ed. Rio de Janeiro, R.J.: Guanabara S.A., 1979.

STELESCU, D.M.; ARINEI, A.; HOMOCIANU, M.; FIFERE, N.; TIMPU, D.; AFLORI, M. Structural characteristics of some high density polyethylene/EPDM blends. Polymer Testing, v. 32, p. 187-196, 2013.

WEYER, L.; WORKMAN JR., J. Practical Guide to Interpretive Near-Infrared Spectroscopy. 1. ed. Boca Raton, FL.: CRC, 2007.

ZHANG, H.; DATTA, R.N.; TALMA, A.G.; NOORDERMEER, J.W.M. Maleicanhydride EPDM as compatibilising agent in NR/BR/EPDM blends. European polymer Journal, v. 46, p.754-766, 2010. 


\section{INSTITUTO DE PESQUISAS ENERGÉTICAS E NUCLEARES}

Diretoria de Pesquisa, Desenvolvimento e Ensino

Av. Prof. Lineu Prestes, 2242 - Cidade Universitária CEP: 05508-000

Fone/Fax(0XX11) 3133-8908

SÃO PAULO - São Paulo - Brasil

http://www.ipen.br

O IPEN é uma Autaquia vinculada à Secretaria de Desenvolvimento, associada à Universiade de São Paulo e gerida técnica e administrativamente pela Comissão Nacional de Energia Nuclear, órgão do Ministério da Ciência, Tecnologia e Inovação. 